\title{
Essays on the publicness of education and the effects of school choice on student achievement
}

Kerry A. King

West Virginia University

Follow this and additional works at: https://researchrepository.wvu.edu/etd

\section{Recommended Citation}

King, Kerry A., "Essays on the publicness of education and the effects of school choice on student achievement" (2005). Graduate Theses, Dissertations, and Problem Reports. 2244.

https://researchrepository.wvu.edu/etd/2244

This Dissertation is protected by copyright and/or related rights. It has been brought to you by the The Research Repository @ WVU with permission from the rights-holder(s). You are free to use this Dissertation in any way that is permitted by the copyright and related rights legislation that applies to your use. For other uses you must obtain permission from the rights-holder(s) directly, unless additional rights are indicated by a Creative Commons license in the record and/ or on the work itself. This Dissertation has been accepted for inclusion in WVU Graduate Theses, Dissertations, and Problem Reports collection by an authorized administrator of The Research Repository @ WVU.

For more information, please contact researchrepository@mail.wvu.edu. 


\title{
Essays on the Publicness of Education and the Effects of School Choice on Student Achievement
}

\author{
Kerry A. King \\ Dissertation Submitted to the \\ College of Business and Economics at \\ West Virginia University \\ in partial fulfillment of the requirements for the degree of \\ Doctor of Philosophy \\ in \\ Economics

\begin{abstract}
Russell S. Sobel, Ph.D., Chair Stratford M. Douglas, Ph.D. Santiago M. Pinto, Ph.D.

Mehmet S. Tosun, Ph.D.

Department of Economics

Morgantown, West Virginia 2005
\end{abstract} \\ Subhayu Bandyopadhyay, Ph.D.
}

Keywords: charter school, education, school choice, voucher

Copyright (C) 2005 Kerry A. King 


\title{
ABSTRACT \\ Essays on the Publicness of Education and the Effects of School Choice on Student Achievement
}

\author{
Kerry A. King
}

This dissertation is a collection of papers that focus on the effects of school choice in the education market. The first chapter introduces the concept of school choice and discusses the arguments both for and against its implementation into public education. In addition, this chapter outlines the research agenda for this dissertation. Chapter 2 empirically measures the spillover benefits created by K-12 public education and finds that they are not Pareto-relevant at the margin. Given the results, this chapter also examines the role of school choice in the market for K-12 public education. Chapter 3 provides a brief history of school choice in the United States and discusses how it has developed and changed the education market over the past two decades. Chapter 4 empirically analyzes and compares for-profit and nonprofit charter schools and the effects each has on student achievement levels. The results show that the structure of for-profit charter schools create incentives that contribute to higher student achievement levels when compared to their nonprofit counterparts. Chapter 5 analyzes how the implementation of a voucher program affects both urban and rural public school performance in the Cleveland, Ohio region. Results indicate that competition for students has a positive impact on both urban and rural student achievement with greater effects being found in the urban areas as expected. Chapter 6 summarizes the major findings of the research chapters, presents the policy implications of the research, and proposes areas of future research. 


\section{ACKNOWLEDGEMENTS}

I would like to thank my dissertation chair, Russell S. Sobel, for his unyielding support and guidance throughout both my undergraduate and graduate career at West Virginia University. Russ always went above and beyond his duties as an advisor and mentor and I feel very fortunate to have had the opportunity to work with him.

I would also like to thank the remaining members of my committee, Subhayu Bandyopadhyay, Stratford M. Douglas, Santiago M. Pinto, and Mehmet S. Tosun for all of their help both in the classroom and during my writing process. 


\section{TABLE OF CONTENTS}

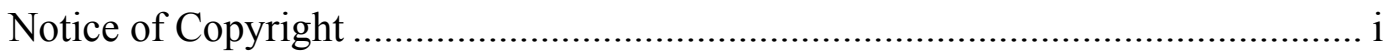

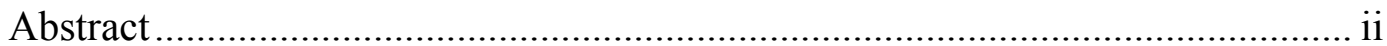

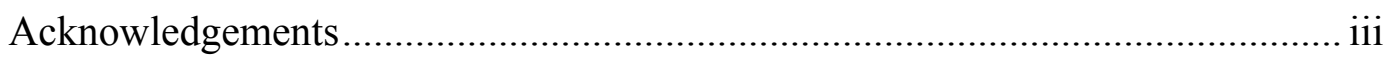

List of Tables and Figures...................................................................... vi,vii

Chapter 1:

The Publicness of Education, School Choice, and Student Achievement

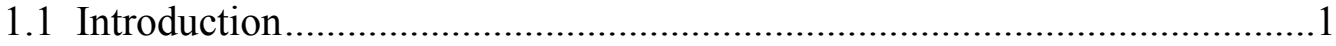

1.2 Dissertation Research Agenda …………………....................................

Chapter 2:

Do Spillover Benefits Create a Market Inefficiency in K-12 Public Education?

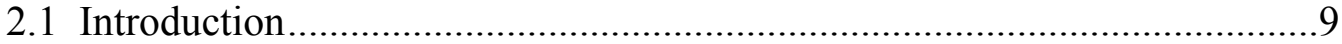

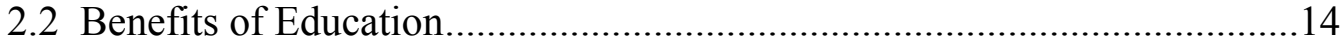

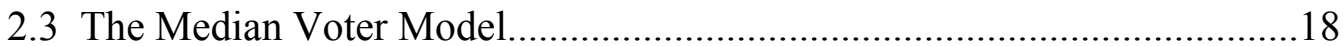

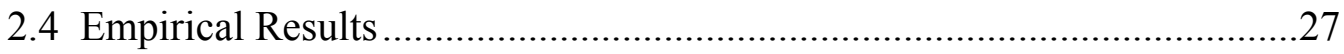

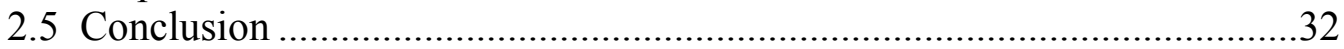

Chapter 3:

The History of School Choice

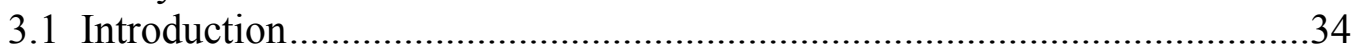

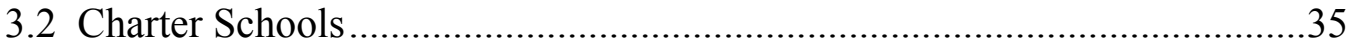

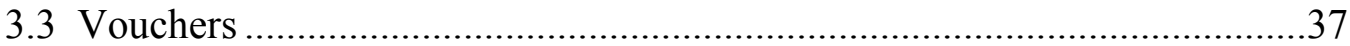

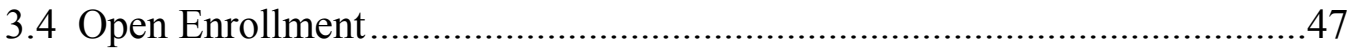

3.5 Tax Credit and Tax Deduction Programs ………………..........................50

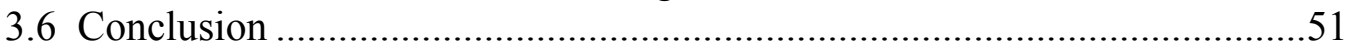

Chapter 4:

Charter Schools in Arizona: Does Being a For-Profit Institution Make a Difference?

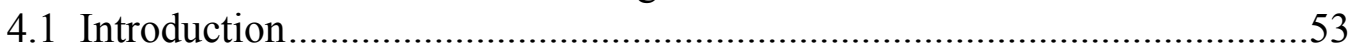

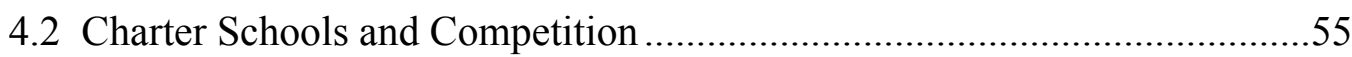

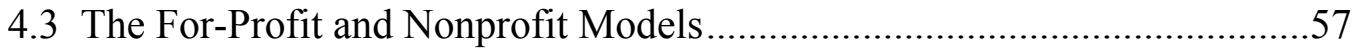

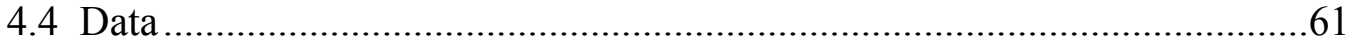

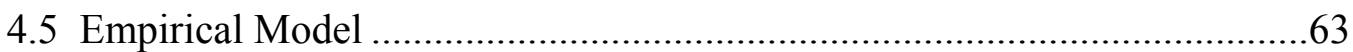

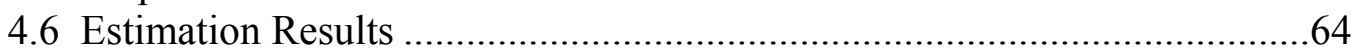

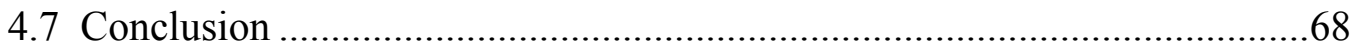




\section{Chapter 5:}

The Effects of Vouchers on Student Achievement in Urban and Rural Districts:

Evidence from Cleveland, Ohio

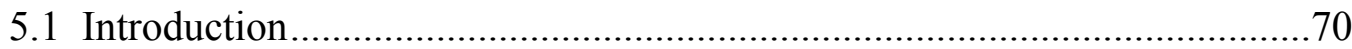

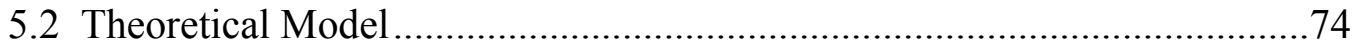

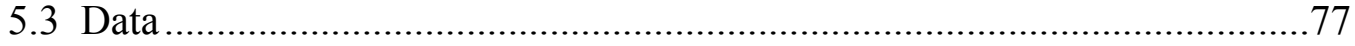

5.4 Empirical Model and Estimation Results .................................................79

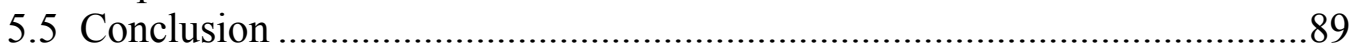

Chapter 6:

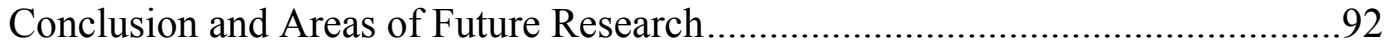

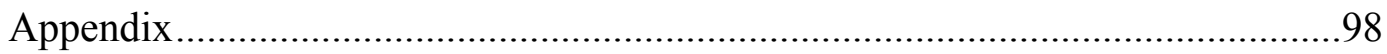

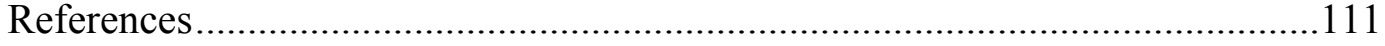




\section{LIST OF TABLES AND FIGURES}

\section{TABLES:}

Table 2.1 Public Finance Approaches to Characterizing the Spillover Benefits..11 Created by K-12 Education

Table 2.2 Cross-section K-12 Public Expenditure Estimates Excluding Cost ....29 Variables

Table 2.3 Cross-section K-12 Public Expenditure Estimates Including Cost ......31 Variables

Table 3.1 Charter School Numbers by State as of January 2005.........................38

Table 3.2 Voucher Program Student Enrollment..............................................44

Table 3.3 Open Enrollment Laws in the United States as of December 2002......49

Table 3.4 Tax Credit and Deduction Programs ...............................................50

Table 4.1 Charter Schools and Enrollment for Arizona (1995-2004) ..................57

Table 4.2 Estimated Determinants of Student Achievement Using a...................65 For-Profit and Nonprofit Comparison, Dependent Variable: Average Test Score on the Stanford 9

Table 4.3 Estimated Determinants of Student Achievement Using a 67 For-Profit and Nonprofit Comparison, Dependent Variable: Average $3^{\text {rd }}$ Grade Test Score on Arizona's Instrument to Measure Standards Exam

Table 4.4 Estimated Determinants of Student Achievement Using a .68 For-Profit and Nonprofit Comparison, Dependent Variable: Average $5^{\text {th }}$ Grade Test Score on Arizona's Instrument to Measure Standards Exam

Table 5.1 The 12 School Systems in the Greater Cleveland Area and the 78 Associated Number of Schools

Table 5.2 Cleveland Municipal $4^{\text {th }}$ Grade Estimation Results: School Years .....83 2002-03 and 2003-04

Table 5.3 Lakewood City $4^{\text {th }}$ Grade Estimation Results: School Year...... .84 2002-03 and 2003-04

Table 5.4 Mentor Exempted Village $4^{\text {th }}$ Grade Estimation Results: School .......85 Year 2002-03 and 2003-04

Table 5.5 Willoughby-Eastlake $4^{\text {th }}$ Grade Estimation Results: School Year ......86 2002-03 and 2003-04

Table 5.6 Pooled Estimation Results, All Schools: School Year 2002-03 and ...87 2003-04

Table 5.7 Pooled Estimation Results with Interaction Term: School Years........88 2002-03 and 2003-04

Table A.1 Variable Definitions and Data Sources...........................................100

Table A.2 Estimated Determinants of Student Achievement, 2002-03 ..............101 Dependent Variable: Average Test Score on the Stanford 9 Exam

Table A.3 Estimated Determinants of Student Achievement, 2003-04 ..............102 Dependent Variable: Average Test Score on the Stanford 9 Exam

Table A.4 Estimated Determinants of Student Achievement, 2002-03, ,............103 2003-04 Dependent Variable: Average Test Score on AIMS Exam 
Table A.5 Estimated Determinants of Student Achievement, 2002-03,............104 2003-04 Dependent Variable: Average Test Score on AIMS Exam

Table A.6 Variable Definitions and Data Sources............................................105

Table A.7 Cleveland Municipal and Comparable School Characteristics..........106

Table A.8 Lakewood City and Comparable School Characteristics..................107

Table A.9 Mentor Exempted Village and Comparable School .........................108 Characteristics

Table A.10 Willoughby-Eastlake and Comparable School Characteristics ......109

Table A.11 Voucher Estimation Results: School Year 2002-03 and................110 2003-04

FIGURES:

Figure 2.1 Construction of the Marginal Social Benefit Curve ...........................17

Figure 2.2 Measuring the Degree of Publicness of K-12 Education ....................21

Figure 2.3 Construction of the Marginal Social Benefit Curve as Population .....22 Increases from $\mathrm{N}$ to $\mathrm{N}+1$ 


\section{Chapter 1}

\section{The Publicness of Education, School Choice, and Student Achievement}

\subsection{Introduction}

School choice is defined as a public school program that allows students to choose to attend any of various participating private and public schools. ${ }^{1}$ Over the past two decades, school choice has become a major topic in the realm of education reform. In order to understand the importance of the school choice movement it is beneficial to look at why education policy has changed over the past several decades and how the need for reforms have led many to believe that parental choice is the only solution for improving the plight of K-12 public education in the United States.

Walberg and Bast (2003) point to three books that have substantially influenced the national debate on how best to organize K-12 schooling in the United States: Capitalism and Freedom (1962) by Milton Friedman; A Nation at Risk (1983) produced by the National Commission on Excellence in Education; and Politics, Markets and America's Schools (1990) by John Chubb and Terry Moe.

Capitalism and Freedom (1962) is a book devoted to explaining the proper role of government in a free society. One of the chapters titled, "The Role of Government in Education," calls for a new approach to the financing of education where governments would give parents vouchers redeemable for a specified sum to use for the child's educational expenses. Parents would then be free to choose an "approved" institution to spend the sum of money for their child's education. In the book, Friedman also specified

\footnotetext{
${ }^{1}$ The American Heritage ${ }^{\circledR}$ Dictionary of the English Language, Fourth Edition Copyright $₫$ 2004, 2000 by Houghton Mifflin Company. Published by Houghton Mifflin Company.
} 
that "the role of government would be limited to ensuring that the schools met certain minimum standards, such as the inclusion of a minimum common content in their programs, much as it now inspects restaurants to insure that they maintain minimum sanitary standards."2

Even though at the time the above mentioned chapter in Capitalism and Freedom did not get much attention from a national audience, over the past decade as voucher programs have begun to take shape across the country, Friedman has been referenced as the first person to attempt to develop school choice as a possible solution to the problems facing K-12 public education.

In 1983 after studying the American education system, The National Commission on Excellence in Education published an alarming federal report entitled A Nation at Risk: The Imperatives for Educational Reform. The Commission found that "American students were not studying the right subjects, were not working hard enough, and were not learning enough." This report also warned that "our social structure would crack, our culture erode, our economy totter, [and] our national defenses weaken" if the United States did not make immediate attempts to remedy the situation by finding a cure for our fatally-ill education system. ${ }^{3}$ The publication of $A$ Nation at Risk made education reform a permanent issue on the national agenda and opened the door for school choice to once again become a relevant topic of debate among policymakers.

In response to A Nation at Risk, the late 1980s and early 1990s saw an abundance of reforms take place as elected officials worked to improve the status of K-12 education. Popular reforms included increasing teacher salaries, reducing class size, changing

\footnotetext{
${ }^{2}$ Friedman, Milton, 1962. Capitalism and Freedom. Chicago: University of Chicago Press.

${ }^{3}$ National Commission on Excellence in Education, 1983. A Nation at Risk: The Imperatives for Educational Reform Washington, D.C.: U.S. Department of Education.
} 
student graduation requirements, encouraging greater parental involvement, targeting resources to students in poverty, changing curricula and teaching practices, and much more. ${ }^{4}$ Missing from these reforms were the ideas introduced by Friedman (1962) who believed that markets could more efficiently allocate educational resources than government-run schools.

Chubb and Moe's publication of Politics, Markets and America's Schools in 1990 finally forced policymakers to confront the fact that institutions and incentives matter because schools lack reasons and incentives to reform themselves. "Choice," they wrote, "is a self-contained reform with its own rationale and justification. It has the capacity all by itself to bring about the kind of transformation that, for years, reformers have been seeking to engineer in myriad other ways." ${ }^{6}$ Chubb and Moe concentrate mainly on the issues of why government-run schools are doomed to fail because of political theories of institutional behavior. They only downside to their book is the lack of any explanation from an economic viewpoint on how markets could be implemented to improve the situation. This leads to the debate which is ongoing today on whether or not markets, and therefore competition through school choice, can improve the current educational situation.

Opponents of school choice have voiced a variety of reasons why they think an economics based free market system in education is almost certain to fail. One critic argues that school choice will cause the system to fail the children who are not lucky

\footnotetext{
${ }^{4}$ Walberg, Herbert J., and Joseph L. Bast, 2003. Education and Capitalism: How Overcoming Our Fear of Markets and Economics Can Improve America's Schools. Hoover Institution Press Publication No. 521. ${ }^{5}$ Ibid.

${ }^{6}$ Chubb, John E., and Terry M. Moe, 1990. Politics, Markets, and America's Schools. Washington, DC: The Brookings Institution.
} 
enough to remove themselves from a low-performing school and will therefore "pit student against student and family against family in the struggle for educational survival" (Cookson, 1992). Other critics see choice in American education as serving the interests of the already privileged and increasing the gaps between those who are already successful at manipulating the system and those who are not (for example, Moore and Davenport, 1990). They see choice as driving the privileged and less privileged further apart, exacerbating school inequalities.

Another critique of school choice comes from those who worry about the potential loss of financial support for failing schools. If students move from a failing school in one district to a school in another district, the original district will lose valuable per-pupil funding. Essentially, they do not believe that allowing schools to fail will help the system overall. ${ }^{7}$

Proponents of school choice contend that competition between schools will lead to increased school accountability which will encourage individual schools to experiment with different educational approaches in order to find those that work best for the students they serve (Raywid, 1992). Other proponents such as Coulson (1996) argue that, "the education market rests on two main presumptions: that monopoly control of education leads to coercion, indifference to the needs of families, and stagnation in the form and content of instruction, while competition and the profit motive would lead to greater quality and efficiency." Overall, most school choice advocates contend that giving parents educational options creates healthy competition among schools, providing schools with an incentive to improve. Based on the ideal of the free market, schools must meet the needs of their consumers (parents and students) in order to stay in business.

\footnotetext{
${ }^{7}$ Education Weekly, 2005. Choice. [Online] Available at URL http://www.edweek.org.
} 
Following this theory, if a school does not meet the needs of its students, parents and students should have the option of seeking better education opportunities elsewhere. ${ }^{8}$

As a concept, school choice has existed in some form dating back to the early 1800s. In the past, only the wealthy families who could afford the tuition rates at private schools could exert choice over the school their child attended. A truly free and competitive market in education can only exist when barriers to entry are eliminated. Therefore, in order to understand the effects of school choice on student achievement, the types of school choice that I will analyze are those which work to minimize these restrictions and allow parents to truly have a choice in what school their child attends.

\subsection{Dissertation Research Agenda}

There are four research chapters included in this dissertation that will present specific applications of the economics of school choice. A major criticism of school choice focuses on the idea that a free market education system would fail precisely because it would operate in the same way as other markets. In other words, education would suffer due to the inherent market failure that exists in the form of positive externalities or spillover benefits. This argument focuses on how an educated individual not only receives private benefits from being educated, but also indirectly benefits their fellow citizens as well. If education does in fact suffer from this type of market failure there would be justification for government intervention and furthermore, competition would be an unlikely solution for improving educational outcomes. Chapter 2 focuses on this argument and measures the publicness of education by estimating the spillover benefits created by K-12 public education. The empirical results show that K-12 public

\footnotetext{
${ }^{8}$ Ibid.
} 
education does not suffer from a positive externality problem and therefore from an efficiency standpoint, school choice can work to improve educational outcomes by incorporating competition into the education market.

Chapter 3 chronicles the development of four popular school choice options in the United States: charter schools, vouchers, open enrollment, and tax credit and tax deduction programs. Charter schools are publicly funded, privately run institutions that have recently become a key player in the school choice movement. Since the first charter school opened in Minnesota in 1992, the number of charter schools has reached nearly 3,000 and the number of students enrolled is approximately 700,000 for children in grades K-12.' This chapter discusses how the idea of 'chartering' a school first began and also how it eventually evolved into one of the most popular forms of school choice in the United States today. Next, this chapter discusses the origins of voucher programs and focuses on their development in the areas of Maine, Vermont, Milwaukee, Wisconsin, Cleveland, Ohio, and the District of Columbia. This chapter also discusses the legal battles voucher programs have faced and the current status of voucher legislation. Finally this chapter defines and explains the development of the school choice options of open enrollment and tax credit and tax deduction programs and gives a list of where these options can be found throughout the United States.

Chapters 4 and 5 present specific examples on how certain types of school choice options affect student achievement levels. Chapter 4 tests whether or not the profit motive in charter schools has an impact on student achievement. A study by Hoxby (2003) models the for-profit motive in education and finds that the distribution of the surplus is the key difference between for-profit and nonprofit schools. For-profit schools can

\footnotetext{
${ }^{9}$ The Center for Education Reform, 2005. [Online] Available at URL http://www.edreform.com.
} 
distribute surplus in the form of cash to its shareholders, while nonprofit schools distribute its surplus in other ways through equipment, books and supplies, etc. The motivation to improve school quality is therefore greater in the for-profit schools and thus higher student achievement is the predicted result. This chapter empirically tests Hoxby's theory and is able to confirm that for-profit charter schools exhibit higher student achievement levels when compared to their nonprofit counterparts. This implies that incentives do matter in education and therefore policymakers should focus on how competition and the profit motive can work together to improve the current state of K-12 public education.

Chapter 5 analyzes the effects of vouchers on public schools in the greater Cleveland area. Vouchers, or scholarships as they are sometimes called, are payments made to parents, or institutions on a parent's behalf, to be used for a child's education expenses. In Cleveland, only private schools are currently participating in the scholarship program and families must be below 200 percent of the poverty level to be eligible. This paper focuses on four school districts in the Cleveland Metropolitan area. The school districts are separated into the categories of urban and rural based on population density. Each of the four districts are grouped with comparable schools across the state and the effects of the voucher program are empirically estimated using a standard educational production function and the value-added approach. The results indicate that both urban and rural public schools in the voucher area are seeing higher levels of proficiency on average when compared to public schools outside the voucher region. In addition, the urban public schools are seeing more of an impact than the rural regions which coincides with the goals of the voucher program. 
Finally, Chapter 6 concludes the dissertation by summarizing the major findings of each of the research chapters and highlighting the importance of each. This chapter also provides some final thoughts on the policy implications of the dissertation and proposes future areas of research. 


\section{Chapter 2}

\section{Do Spillover Benefits Create a Market Inefficiency in K-12 Public Education?}

\subsection{Introduction}

In economics there is a well-established framework for determining whether government intervention into a market is justified. If we look from the perspective of economic efficiency, government intervention has the potential to improve the market outcome when a market failure exists. As Bator (1958) suggests, certain categories of market failures such as public goods, externalities, and monopoly all contain certain properties that lead to an allocation of resources which is not Pareto-efficient. The use of the word potential is important to note when referring to government intervention and improved market outcomes because modern public choice theory also suggests the presence of government failures. It is conceivable that even in a case where the private market fails to reach efficiency, government intervention might actually worsen, rather than improve, the situation. A possible explanation for this occurrence is given by Buchanan (1962) who discusses the concept of political externalities which refer to situations where political action is carried out without unanimous consent thereby reducing the choice set of agents. In addition, Sobel (2004) argues that in some cases it may be preferable to have an unregulated "bad" market outcome as opposed to the outcome that results with government intervention. ${ }^{10}$

\footnotetext{
${ }^{10}$ For example, Husted and Kenny, (2000) find that government policies that equalize spending within a state make schools less efficient.
} 
One of the more interesting markets within which to apply these theories is K-12 public education. Even among economists, there remains debate over the extent to which this market is characterized by Pareto-relevant spillover effects or positive externality type problems. Table 2.1 lists a variety of popular textbooks used to teach undergraduate public finance, and also demonstrates the various authors' views on whether the spillover benefits created by K-12 public education are Pareto-relevant or Pareto-irrelevant. It is interesting to note that there is no clear consensus reached on how to treat the spillover effects that result from K-12 education. Although the authors listed all agree that education does suffer from some form of externality problem, whether or not this problem impacts market efficiency is the focal point of the debate. Anderson (2003) and Hyman (2002) define public goods as a special case of externalities and describe education as a 'partially public good.' According to this definition, the market fails due to the Pareto-relevant spillover benefits created by education thus justifying government intervention from an efficiency standpoint. Fisher (1996) argues that government intervention is justified because education produces external benefits such as the gains to all from a literate society. Rosen (2002) claims that education can give rise to a market failure due to the externality characteristics that it contains. In particular, Rosen (2002) explains that even though most people consider public education to be primarily a private good, there are those who argue that it may also be the case that education gives rise to public goods. Rosen argues that if education does contain public qualities then a possible explanation for government subsidization exists.

Holcombe (1996) and Bruce (2001) enter the debate by using the term inframarginal to describe the type of externality created by education. With inframarginal 


\section{Table 2.1 Public Finance Approaches to Characterizing the Spillover Benefits Created by K-12 Education}

\begin{tabular}{|c|c|c|}
\hline & $\begin{array}{l}\text { Pareto-relevant } \\
\text { externality. }\end{array}$ & $\begin{array}{l}\text { Pareto-irrelevant } \\
\text { externality. }\end{array}$ \\
\hline Anderson (2003), Public Finance & $\begin{array}{l}\mathrm{X} \text { (education is a } \\
\text { 'partially public } \\
\text { good') }\end{array}$ & \\
\hline $\begin{array}{l}\text { Bruce (2001), Public Finance and the } \\
\text { American Economy }\end{array}$ & & $\mathrm{X}$ (inframarginal) \\
\hline $\begin{array}{l}\text { Fisher (1996), State and Local Public } \\
\text { Finance }\end{array}$ & $X$ & \\
\hline Holcombe (1996), Public Finance & & $\mathrm{X}$ (inframarginal) \\
\hline $\begin{array}{l}\text { Hyman (2002), Public Finance, } A \\
\text { Contemporary Application of Theory To } \\
\text { Policy }\end{array}$ & $\begin{array}{l}\mathrm{X} \text { (education is a } \\
\text { 'partially public } \\
\text { good') }\end{array}$ & \\
\hline Rosen (2002), Public Finance & $\mathrm{X}$ & \\
\hline $\begin{array}{l}\text { Stiglitz (2000), Economics of the Public } \\
\text { Sector }\end{array}$ & & $\mathrm{X}$ \\
\hline $\begin{array}{l}\text { Ulbrich (2003), Public Finance In } \\
\text { Theory and Practice }\end{array}$ & $X$ & \\
\hline
\end{tabular}

externalities, individuals are taking account of the full benefits or costs of their actions, at the margin. Inframarginal externalities do not necessarily imply an inefficient allocation of resources because even though there may be some spillovers of benefits or costs to others, there are no marginal benefits or costs. ${ }^{11}$ For example, suppose an industry pollutes a nearby lake which kills all of the fish and makes it unsuitable for swimming. Assume the industry were to reduce the amount of pollution it creates but even after doing so the fish are still unable to survive and swimming still is not safe. In this case the

\footnotetext{
${ }^{11}$ Holcombe, Randall G., 1996. Public Finance: Government Revenues and Expenditures in the United States Economy. West Publishing Company, 91-94.
} 
externality is inframarginal because a marginal reduction in the amount of pollution does not make anyone better off and a marginal increase in the amount of pollution does not make anyone worse off.

In the case of education, the question is whether or not the spillover benefits created by individuals who become educated are relevant at the margin. If incentives exist so that individuals will receive enough of an education to be able to function in society, the positive externalities derived from an educated population are inframarginal and therefore do not constitute a reason for government intervention in the production of K-12 education. The marginal units of education do not confer the externality; it is the inframarginal units that individuals have the private incentive to obtain anyway. ${ }^{12}$ Therefore, if the spillover benefits from K-12 education are inframarginal, the efficient amount of education can still be produced by market forces.

In addition, although Stiglitz (2000) does not use the inframarginal argument directly, the author does maintain that for industrial cities such as the United States, government subsidies based on externality problems are unproved, implying that at the margin, the spillover benefits created by an educated population are not Pareto-relevant. Stiglitz (2000) does argue for government subsidies on distributional grounds supporting government financing as a justifiable type of government intervention in the education market. Ulbrich (2003) explains that there are two possible justifications for government intervention in public education. First, from an efficiency standpoint the rationale is again the externality argument. The second claim, similar to that of Stiglitz (2000), deals with equity and the idea that education is a merit good. In this case, the role of government

\footnotetext{
${ }^{12}$ Ibid.
} 
deals with the public financing aspect of government intervention, not the public production of education which this paper models. ${ }^{13}$

Even more importantly, however, determining whether a market failure exists in the private production of K-12 education has important implications for public policy. While the production of K-12 education has been and continues to be dominated by the public sector, there has been significant support for introducing competition into K-12 education by creating stronger market forces through vouchers, tax credit or tax deduction programs, school choice and charter schools. There are currently 13 states which have adopted either a publicly funded voucher program, or implemented a tax credit or tax deduction program and 42 states that have charter school laws. ${ }^{14}$ The degree of potential market failure in K-12 education has significant implications for whether these increased privatization efforts have the potential to improve educational outcomes. If the K-12 education market is subject to significant spillover effects or externality type problems, these efforts are likely to produce disappointing results. On the other hand, if the K-12 education market is not subject to this type of market failure, there is clearly a justification for the use of market forces to improve educational outcomes. In fact, if K-12 education is not subject to this problem, it eliminates the case for government production of education entirely from an efficiency standpoint, although arguments for public financing based on equity grounds could still be valid.

\footnotetext{
${ }^{13}$ The public financing aspect of government intervention is analyzed by Toma (1996). The author finds that the source of funding for education does not impact private school effectiveness. The political restrictions placed on the decision-making of private schools are instead the important factors affecting efficiency.

${ }^{14}$ The following states have vouchers, tax credit, or tax deduction programs: AZ, CO, District of Columbia, FL, IL, IA, ME, MN, OH, PA, PR, VT and WI. (Source: Education Commission of the States, 2005. \{Online] Available at URL http://www.ecs.org).

States without charter laws: AL, KY, ME, MT, NE, ND, SD, VT and WV. (Source: The Center For Education Reform, 2004. [Online] Available at URL http://www.edreform).
} 
In this chapter, I present and estimate a model that produces a measure of the degree to which K-12 public education creates Pareto-relevant external benefits to the median voter. Applying an empirical median voter demand curve model, I am able to obtain an estimate (on a scale of $0 \%$ to $100 \%$ ) of the degree to which $\mathrm{K}-12$ public education is really a pure private good producing no spillover effects. My results suggest that $\mathrm{K}-12$ education is almost entirely a pure private good, creating little to no external benefits to the median voter (above and beyond his or her own private benefit from K-12 education).

The set up of this chapter is as follows. Section 2.2 will discuss the benefits of K12 education and how spillover or external benefit arguments apply to this case. Section 2.3 will present the theoretical model from which the empirical model is developed. Section 2.4 will estimate the model using data from all 50 states including the District of Columbia for the 1979-80, 1989-90, and 1999-00 school years and Section 2.5 will present concluding thoughts and implications of this analysis.

\subsection{Benefits of Education}

When an individual becomes more educated, other people besides that individual are made better off as well. For instance, if we suppose a certain individual goes to medical school and then one day uses her academic research to cure cancer, then this education will have made many people better off. However, these spillover benefits only create problems for markets when a person is not compensated for the generation of these spillover benefits. In competitive markets, labor earns its value of marginal product, and the individual mentioned above will be well compensated for inventing the cure for 
cancer. Thus, these types of spillover benefits that result from greater individual knowledge contributing to economic progress are fully internalized into one's own individual demand curve for education. At issue is whether education produces any spillover benefits that the individual does not fully internalize. The most compelling argument is that as individuals become educated, others benefit from their ability to create a common cultural heritage and share a common language and numbering system which facilitates trade and human interaction on a broader social scale. It can be argued that these types of benefits may not be fully internalized by the individual receiving the education. Although individuals do have private incentives to get some basic form of education in order to function in society, the benefits that accrue to the population as a whole may not be fully internalized in their own private demand for education and therefore could be impacting market efficiency. For the remainder of this paper I will use the term spillover benefits only when referring to these types of external benefits, excluding the positive benefits that accrue to others for which the individual is able to fully internalize the externality through her market earnings.

It is important for a moment to digress into a discussion of whether at the margin, these spillover benefits are a case of a relevant positive externality problem or an irrelevant positive externality problem. Even if K-12 education creates a positive externality, this does not necessarily imply the presence of a market failure. As mentioned previously, and by following Buchanan and Stubblebine (1962), some externalities can be inframarginal, and thus not Pareto-relevant. ${ }^{15}$ This may be the case if the external benefits produced in the first few years of education are followed by

\footnotetext{
${ }^{15}$ See the Appendix for a mathematical derivation of inframarginal externalities as shown in Buchanan and Stubblebine, 1962.
} 
additional years of education which fail to produce additional external benefits. As Holcombe (1996) argues, the external benefits accruing from the knowledge of a common language and numbering system are produced almost entirely in the first few early years of school.

In addition to the first few years of elementary education it can be argued that students also gain certain skills from the first few years of secondary education, which gives them the ability to create external social benefits that are not entirely compensated through market earnings. For instance, everyone as a consumer is benefited by the presence of other informed consumers in the marketplace. In addition, everyone benefits from active and informed citizens participating in the political process, acting as watchdogs if nothing else.

It is important to note that once an individual goes beyond these first few years of elementary and secondary education, additional years of education might create private benefits, but fail to produce additional, uncompensated, spillover benefits. To better demonstrate this distinction, Figure 2.1 shows how the marginal social benefit curve of education might be constructed from the sum of the private (individual) demand for education and the marginal external benefit curve reflecting any spillover effects. For simplicity of discussing the impact this has on optimal provision, a constant marginal cost curve is used to facilitate finding the socially optimal quantity in each case. Three cases are illustrated in Figure 2.1. Case (a) illustrates a situation in which every additional unit of education creates an external benefit. In this case, the marginal social benefit curve appears to be shifted upward in a parallel fashion through the addition of the external benefits into the calculation. This is the standard case shown to justify public subsidies to 
Figure 2.1 Construction of the Marginal Social Benefit Curve
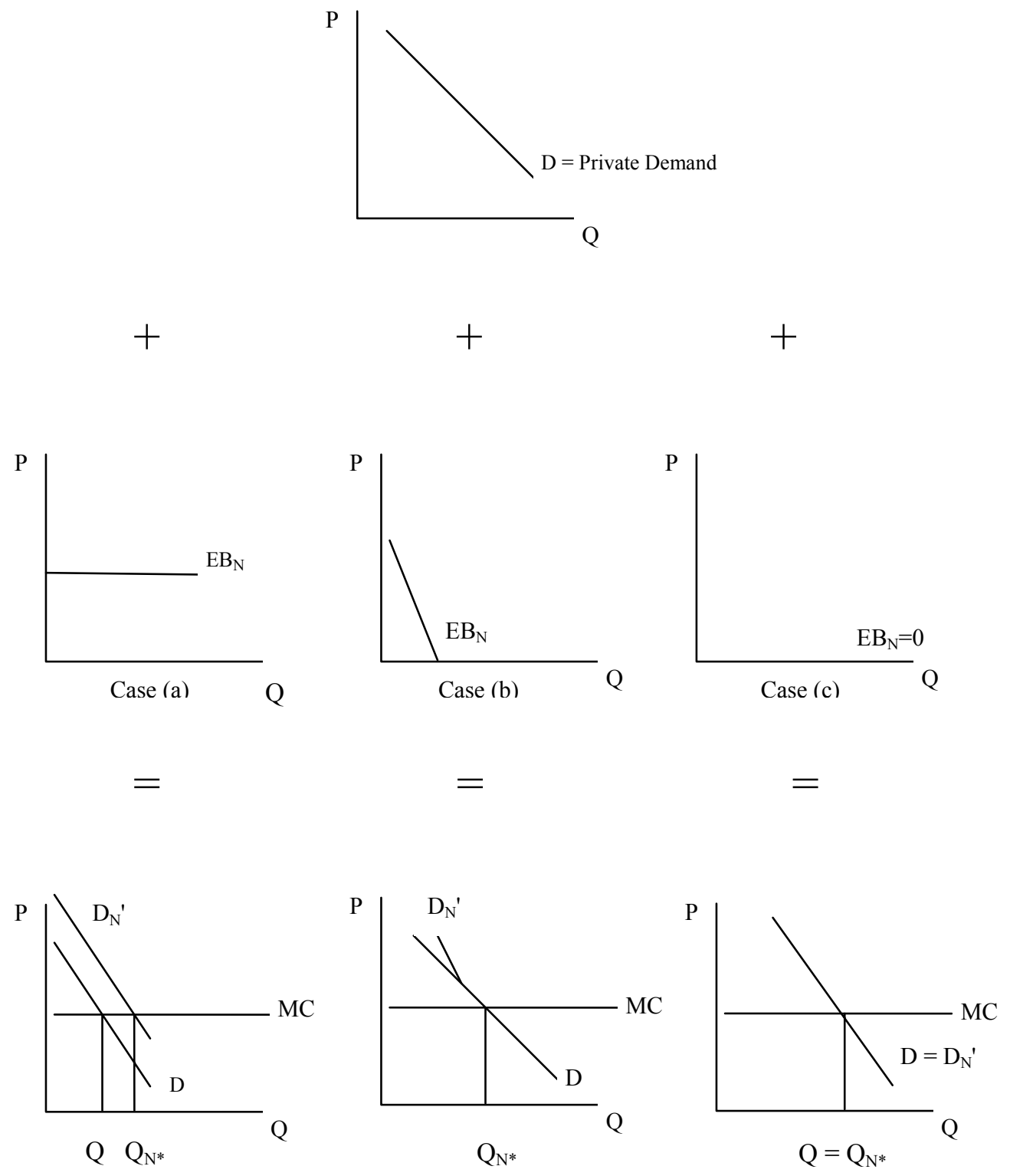

Note. $\mathrm{D}_{\mathrm{N}}$ ' represents the marginal social benefit curve which is the sum of the private demand for education $(\mathrm{D})$ and the marginal external benefits $\left(\mathrm{EB}_{\mathrm{N}}\right)$ reflecting any spillover effects.

K-12 education. The optimal provision $\left(\mathrm{Q}_{\mathrm{N}}{ }^{*}\right)$ is at the intersection of $\mathrm{MC}$ and $\mathrm{D}_{\mathrm{N}}{ }^{\prime}$ which is greater than the private market provision $(\mathrm{Q})$ at the intersection of $\mathrm{MC}$ and $\mathrm{D}$. Case (b) illustrates a situation in which the external benefits are present for the first few units, but 
begin to decline and eventually additional units do not generate additional spillover benefits. Because $\mathrm{D}$ and $\mathrm{D}_{\mathrm{N}}{ }^{\prime}$ merge before the intersection with $\mathrm{MC}$, the presence of these external benefits does not impact market efficiency. On the marginal unit produced, the externality is not Pareto-relevant. It is important to note that the position of the private demand curve for education, (D), plays a significant role in whether or not the spillover benefits impact market efficiency. If the private demand curve was shifted far enough to the left, the spillover benefits would become relevant at the margin. This is also the case for the position of the marginal cost curve. If the marginal cost of providing education was high enough, the spillover benefits would be Pareto-relevant. Case (c) illustrates the final case in which there exists no external benefits at all, and the private and social benefit curves are identical (thus no market failure).

\subsection{The Median Voter Model}

In order to test for the presence of these Pareto-relevant external benefits shown in Figure 1, Case (a), I employ a median voter demand curve model. Originally developed by Bowen (1943), conceptually enriched by Downs (1957) and by Black (1958), this model is frequently used to measure empirically, the degree of publicness (versus pure privateness) for a good produced by the public sector. A few such examples include Holcombe and Sobel (1995) who test the degree to which legislative activity is a public good, Deno and Mehay (1987) who use the median voter model to analyze the expenditure levels adopted by two forms of government, and Bergstrom and Goodman (1973) and Borcherding and Deacon (1972) who analyze the demand for various public 
goods and services. In addition, Langbein (2004) uses the median voter model to analyze whether a publicness element is present for public school music.

The empirical validity of the median voter model has been tested by Holcombe (1980) in which the author uses data from millage issue elections in Michigan which determine the financing for public elementary and secondary education in this particular state. ${ }^{16}$ The results of this study show that the actual millage rate in the average school district is not significantly different from the median voter's preferred rate and thus the median voter model provides a good empirical estimate of the Bowen equilibrium. Inman (1978) also provides empirical evidence that the median voter model is a good predictor of reality showing that a sample of Long Island schools created their budgets "as if the median income family were decisive."

The model employed here attempts to analyze whether a change in population results in a change in the quantity of the education provided. The logic is that for a good that is joint-in-consumption, if another individual were to relocate into the community, they could share in the amount already being produced. Thus, the optimal quantity does not change with the size of the population. The benefits from the production of the education can be extended to additional people at zero marginal cost. Rather than estimating whether the coefficient on population is zero, however, this test takes into account that the tax cost per person is also reduced as more people consume the education already being produced, which should result in a higher quantity demanded and optimal level of provision.

\footnotetext{
${ }^{16}$ The millage rate is the rate of taxation set by the governing authorities and the School Board to produce the necessary revenue to pay for the operation of local government and schools. A millage rate (or tax rate) is derived by dividing the county's operating budget by the total assessed value in the county. A millage rate of 25 mills, or $\$ 25.00$ per thousand, means that the assessed value of the property is multiplied by $\$ 25.00$ for each thousand dollars of the assessment. www.one-ifbyland.com/dictionary.htm
} 
The publicness measure determines the degree to which the social benefit curve is the result of a vertical or horizontal summation of the individual demand curves. Figure 2.2 illustrates this point. For goods that are joint-in-consumption (public goods) a vertical summation is necessary, while a horizontal summation is used for goods that are rival-in-consumption (private goods). When goods are joint-in-consumption the social benefit for any given unit is the total benefit created across all individuals who share in the benefit. When goods are rival-in-consumption, the social benefit for any given unit is simply the benefit to the single consumer who receives it. As shown in Figure 2.2, the degree of publicness, $\alpha$, is a measure of the angle which results from a vertical or horizontal summation of individual demand curves. A smaller angle measure corresponds to a horizontal summation and thus reflects a more private good with little or no relevant spillover benefits and a larger angle corresponds to a vertical summation and a more public good with relevant spillover benefits. For the case of K-12 education, a smaller angle measure would imply that at the margin, the spillover benefits do not significantly impact market efficiency in the production of education.

More precisely to the model here, I am estimating whether a change in population results in a change in the demand curve of the median voter for $\mathrm{K}-12$ education. If the education of others creates spillover benefits for the median voter, his or her marginal benefit curve at every given quantity would shift upward as a larger proportion of the population becomes educated. For example, if the median voter lived in a community with 9 other voters, the height of his or her marginal benefit (demand) curve would be equal to any private benefit received from education plus an additional amount added vertically nine times to reflect the additional spillover benefits. If one more person were 
to move into the community, it would result in an upward vertical shift in the median voter's marginal benefit curve as the additional spillover benefits are generated. Using

Figure 2.2 Measuring the Degree of Publicness of K-12 Education

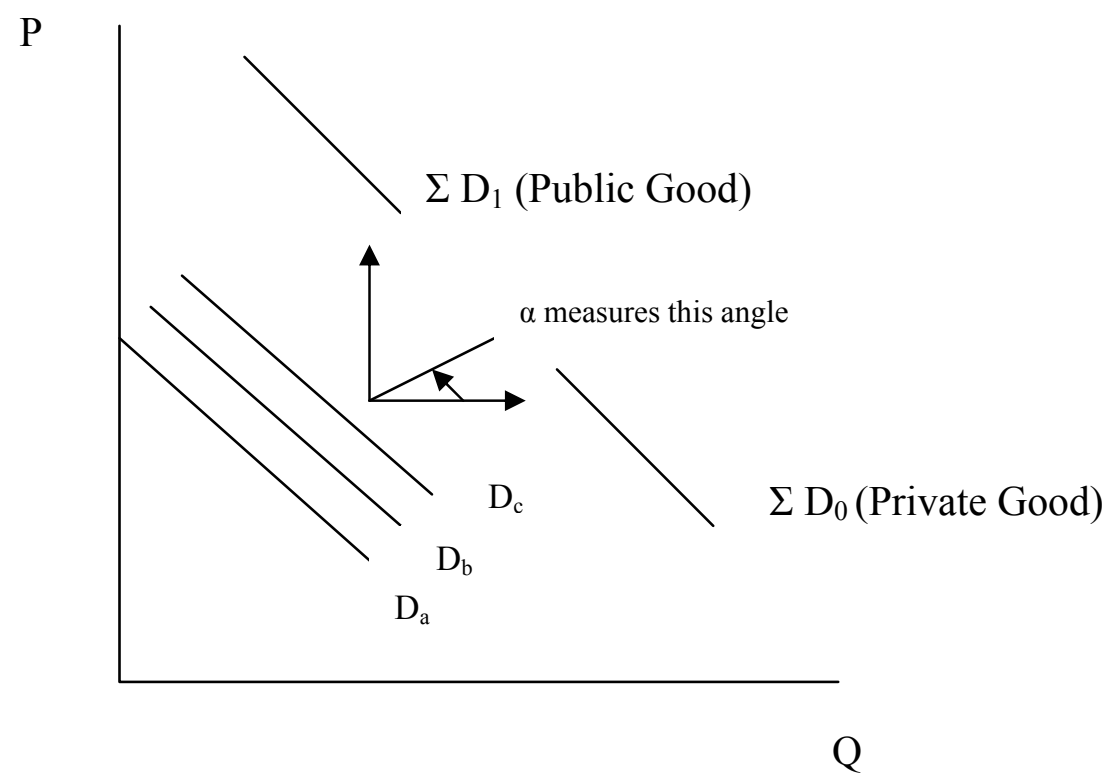

Notes. $D_{a}, D_{b}$, and $D_{c}$ represent individual demand curves which are summed vertically in the case of a public good and horizontally in the case of a private good. The angle that results from either a horizontal or vertical summation of the individual demand curves measures the degree of publicness of education. This measure therefore provides evidence of whether or not the spillover benefits created by K-12 education are Pareto-relevant.

Figure 2.1 we can replicate how the marginal social benefit curve of education is constructed from the sum of the individual private demand curve and the marginal external benefit curve to analyze what happens as population increases by one unit. Figure 2.3, Case (a) shows that as population increases from $\mathrm{N}$ to $\mathrm{N}+1$ the additional external benefits created from each unit of education shifts the demand curve upward from $\mathrm{D}_{\mathrm{N}}$ ' to $\mathrm{D}_{\mathrm{N}+1}$ '. Case (b) represents the situation for which only the first few years of education create spillover effects that are not fully internalized and thus the demand curve shifts from $\mathrm{D}_{\mathrm{N}}$ ' to $\mathrm{D}_{\mathrm{N}+1}$ ', and as before has no impact on market efficiency given the 


\section{Figure 2.3 Construction of the Marginal Social Benefit Curve as Population Increases from $\mathbf{N}$ to $\mathbf{N}+1$}
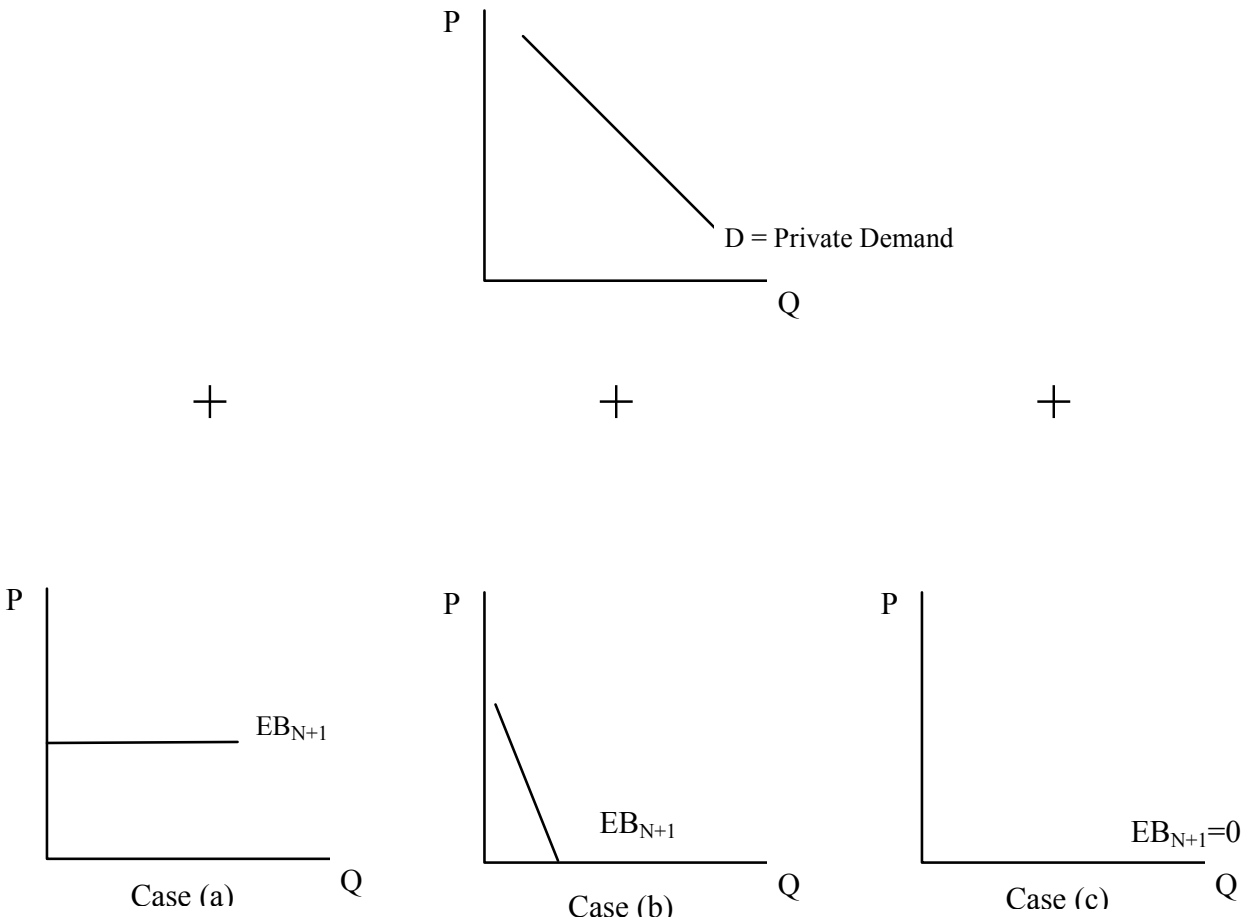

$=$
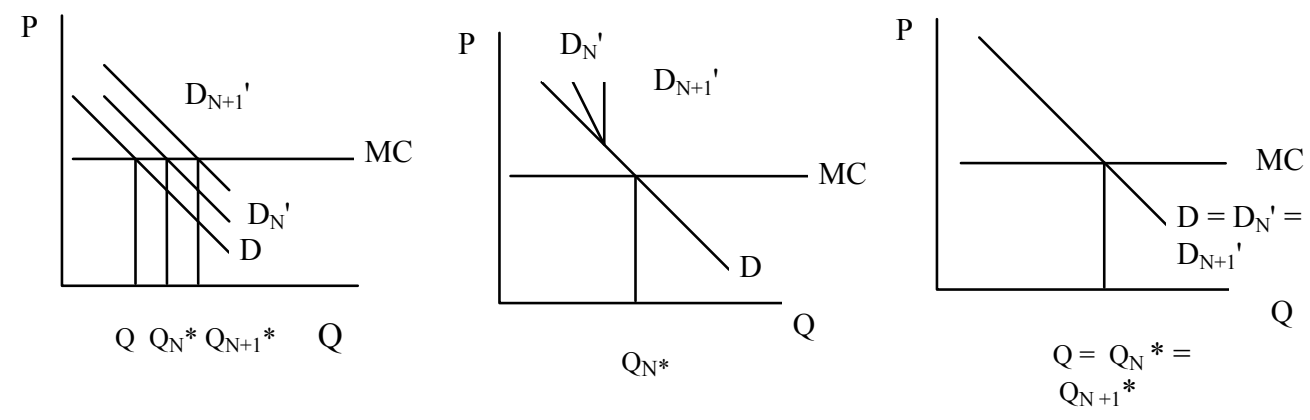

Notes. $\mathrm{D}_{\mathrm{N}}$ ' represents the marginal social benefit curve which is the sum of the private demand for education $(D)$ and the marginal external benefits $\left(\mathrm{EB}_{\mathrm{N}}\right)$ reflecting any spillover effects. $\mathrm{D}_{\mathrm{N}+1}$ represents the marginal social benefit curve after an increase in the population by unit. 
current location of the demand curve, D and the marginal cost curve MC. Case (c) represents the situation with no spillover benefits and therefore the private demand curve equals the social demand curve at $\mathrm{N}$ and $\mathrm{N}+1$.

In order to utilize the median voter model we will assume that spending on public education is determined in a political framework in which voters have demands for the output derived from education. Following the original analysis of public goods by Bowen (1943), it is assumed that public elementary and secondary education can be provided at a constant marginal cost. The marginal cost is divided between the $\mathrm{N}$ individuals who reside in the community for which the school is located. Each individual voter will assume that the costs to him or her are $\mathrm{MC} / \mathrm{N}$. Each voter wants to equate the marginal benefits from an additional unit of output from public education to the tax price MC/N. Following these assumptions, the majority voting rule implies that the median voter's preferences prevail. In addition, it is the case that successful candidates for government office, or more specifically in this case, candidates for the school board, will be those who propose platforms that bring the median voter's marginal tax price in line with his or her marginal benefit.

Voters will decide how much education they desire by comparing the marginal benefits of education with their marginal tax prices. If voters are well informed regarding the costs and benefits of local government services, individual preferences are single peaked and no strategic vote trading occurs. The elected school board candidates will ensure that the marginal tax price charged the median voter equals the marginal benefit received from public education. The quantity of education supplied will therefore be 
equal to the quantity demanded by the median voter. ${ }^{17}$ Let the utility function of the median voter be given by,

$$
\mathrm{U}_{\mathrm{i}}=\mathrm{U}_{\mathrm{i}}\left(\mathrm{X}_{\mathrm{i}}, \mathrm{e}_{\mathrm{i}}\right)
$$

where $\mathrm{e}_{\mathrm{i}}$ is the quantity of public education consumed by the median voter, and $\mathrm{X}_{\mathrm{i}}$ is the quantity of other goods consumed. Of the total amount of education supplied (E) the amount that is consumed by the median voter $\left(\mathrm{e}_{\mathrm{i}}\right)$ can be defined by the function,

$$
e_{i}=N^{-\alpha} E
$$

where $\mathrm{N}$ is the number of people sharing public education. Thus, the value $\alpha=1$ implies that education is a purely private good, and $\alpha=0$ implies that education is a pure public good. Intermediate values of $\alpha$ imply quasi-publicness or quasi-privateness in consumption.

The median voter's demand function for education is found by maximizing (2.1) subject to

$$
\mathrm{Y}_{\mathrm{i}}=\mathrm{P}_{\mathrm{x}} \mathrm{X}_{\mathrm{i}}+\mathrm{T}_{\mathrm{i}} \mathrm{P}_{\mathrm{E}} \mathrm{E}
$$

where $Y_{i}$ is the median voter's disposable income, $P_{X}$ is the price of the other goods $X, T_{i}$ is the voter's tax share, and $\mathrm{P}_{\mathrm{E}}$ is the unit cost of providing education.

Substituting from equation (2.2), the budget constraint can be rewritten as

$$
\mathrm{Y}_{\mathrm{i}}=\mathrm{P}_{\mathrm{x}} \mathrm{X}_{\mathrm{i}}+\mathrm{T}_{\mathrm{i}} \mathrm{P}_{\mathrm{E}} \mathrm{e}_{\mathrm{i}} \mathrm{N}^{\alpha}
$$

which through optimization generates the demand equation

\footnotetext{
${ }^{17}$ Deno and Mehay (1987) use this model to analyze expenditure levels across municipalities to determine the characteristics of local public goods.
} 


$$
\mathrm{e}_{\mathrm{i}}=\mathrm{e}_{\mathrm{i}}\left(\mathrm{P}_{\mathrm{x}}, \mathrm{T}_{\mathrm{i}}, \mathrm{P}_{\mathrm{E}}, \mathrm{N}, \mathrm{Y}_{\mathrm{i}}\right)
$$

For empirical purposes I assume that the unit cost of providing education and the price of other goods are the same across states. In addition, we let the vector A represent differences in tastes across states while using a constant elasticity demand function to produce

$$
e_{i}=A\left(T_{i} N^{\alpha}\right)^{\sigma} Y_{i}^{\lambda}
$$

Using equation (2.2) to substitute for $\mathrm{e}_{\mathrm{i}}$ in equation (2.6), the total demand for $\mathrm{E}$, can be represented by

$$
\mathrm{E}=\mathrm{AT}_{\mathrm{i}}^{\sigma} \mathrm{N}^{\alpha(1+\sigma)} \mathrm{Y}_{\mathrm{i}}^{\lambda}
$$

or

$$
\mathrm{E}=\mathrm{AT}_{\mathrm{i}}^{\sigma} \mathrm{N}^{\theta} \mathrm{Y}_{\mathrm{i}}^{\lambda}
$$

where $\theta=\alpha(1+\sigma)$. Taking logarithms, the median voter's demand equation for $\mathrm{E}$ is

$$
\ln \mathrm{E}=\ln \mathrm{A}+\sigma \ln \mathrm{T}_{\mathrm{i}}+\theta \ln \mathrm{N}+\lambda \ln \mathrm{Y}_{\mathrm{i}}
$$

The median voter's disposable income $\mathrm{Y}_{\mathrm{i}}$, is calculated as

$$
\mathrm{Y}_{\mathrm{i}}=\mathrm{Y}_{\mathrm{i}}^{*}+\mathrm{T}_{\mathrm{i}} \mathrm{G}-\mathrm{F}
$$

where $\mathrm{Y}_{\mathrm{i}}{ }^{*}$ is gross state median income, $\mathrm{G}$ is federal grants to the state in which the 
median voter lives, and $\mathrm{F}$ is the voter's federal tax liability which is calculated by multiplying the average federal tax rate by median income. ${ }^{18}$ The voter's share of federal grants is represented by $\mathrm{T}_{\mathrm{i}} \mathrm{G}$ and is calculated under the assumption that the voter's benefit share is the same as the voter's tax share. $T_{i}$ is calculated by multiplying the average tax rate on income and sales taxes by the median income to get the median state income and sales tax liability, and then dividing this number by total individual income and state general sales tax revenues. ${ }^{19}$ Because median income is a before-tax measure, the median voter's state and federal tax liabilities must be deducted from gross median income $\mathrm{Y}_{\mathrm{i}}{ }^{*}$ in order to obtain the correct measure of disposal income. ${ }^{20}$

The shift parameter in equation (2.9), A, captures any fundamental differences in preferences across states. The variables included to reflect voter preferences are population density (DEN), median age of the residents in the state (AGE), the percent of population non-white (NW), and the percent of the population under 18 (LESSTHAN18).

The median voter's demand equation for public education becomes,

$$
\begin{aligned}
\ln \mathrm{E}=\beta_{1}+ & \beta_{2} \ln \mathrm{TAX}_{\mathrm{i}}+{ }_{\beta 3} \ln \mathrm{POP}+\beta 4 \ln \mathrm{INCOME}_{\mathrm{i}}+\beta_{5} \ln \mathrm{DEN}+\beta_{6} \ln \mathrm{AGE}+ \\
& \beta_{7} \ln \mathrm{NW}+\beta_{8} \ln \mathrm{LESSTHAN} 18+\varepsilon,
\end{aligned}
$$

where $\varepsilon$ is the error term.

\footnotetext{
${ }^{18}$ See Bradford and Oates (1971) for an analysis showing how lump-sum grants have the same impact on local public good demand as a grant given in proportion to an individual's local tax share.

${ }^{19}$ An alternative calculation of $T_{i}$ was also analyzed which included the effective property tax rate, based on the median value home for the year 2000 with no significant changes occurring in the resulting estimates of tax share liability.

${ }^{20}$ Many papers have followed this approach to calculating disposable income. I continue to follow Deno and Mehay (1987) on this issue.
} 
In the above model it was assumed that the unit cost of providing education was the same across states. If we relax this assumption the following variables can be added to equation (2.11) to account for possible cost differences in the production of education in each state: average teacher salary (SALARY), the total number of schools (SCHOOLS), and the percent of schools participating in the National School Lunch Program providing students with free or reduced price lunches (FREELUNCH) ${ }^{21}$ The median voter's demand equation for public education including the cost variables becomes:

$$
\begin{aligned}
& \ln \mathrm{E}=\beta_{1}+\beta_{2} \ln \mathrm{TAX}_{\mathrm{i}}+{ }_{\beta 3} \ln \mathrm{POP}+\beta 4 \ln \mathrm{INCOME}_{\mathrm{i}}+\beta_{5} \ln \mathrm{DEN}+\beta_{6} \ln \mathrm{AGE}+ \\
& \beta_{7} \ln \mathrm{NW}+\beta_{8} \ln \mathrm{LESSTHAN} 18+\beta_{9} \ln \mathrm{SALARY}+\beta 10 \ln \mathrm{SCHOOLS}+ \\
& \beta_{11} \ln \mathrm{FREELUNCH}+\varepsilon,
\end{aligned}
$$

where $\varepsilon$ is the error term.

\subsection{Empirical Results}

Equations (2.11) and (2.12) were estimated using state education data for all states including the District of Columbia for the 1979-80, 1989-90, and 1999-00 school years. ${ }^{22}$ The measure of publicness, $\alpha$, was calculated as $\alpha=\theta /(1+\sigma)=\beta_{3} /\left(1+\beta_{2}\right)$ where $\beta_{3}$ and $\beta_{2}$ are the estimated elasticities of expenditures with respect to population and tax share,

\footnotetext{
${ }^{21}$ Data on the percent of schools participating in the National School Lunch Program (NCLP) was not available for the 1979-80 school year and thus is only used in the 1999-00 and 1989-90 demand equations. Note that 1993-94 school year data is used for the 1989-90 estimates of percent of schools participating in the NCLP.

${ }^{22}$ Data sources are listed in the Appendix, Table A.1.
} 
respectively. The results of equation (2.11) are reported in Table 2.2 and the results for equation (2.12) are found in Table 2.3.

Table 2.2 reveals that for the 1999-00 school year, education was 97 percent private and thus only 3 percent public. $^{23}$ An F-test was performed to determine whether $\alpha$ was significantly different from one by testing the linear restriction $H_{0}: \beta_{2}-\beta_{3}=-1$. The results indicate that the degree of publicness is in fact not significantly different than one and thus implies that K-12 education is almost entirely a private good with little or no spillover benefits. The same analysis applies to the 1989-90 and 1979-80 school years with the results showing education to be approximately 99 and 97 percent private in each respective school year. The degree of publicness from Table 2.2 implies that K-12 education has been almost entirely a private good for the past three decades with the measure changing very little during this period. This implies that more government intervention in terms of the public production of K-12 education based on an efficiency argument is unfounded given the current level of subsidization that already exists.

Further inspection of Table 2.2 indicates that the tax share elasticity is negative in all three time periods and significant for the 1999-00 and 1989-90 school years. Consistent with previous studies, the estimates for population and income elasticity are positive and significant for all three school years. The coefficients on population density are insignificant in every year which is a common finding in most empirical studies of this nature. ${ }^{24}$ The positive coefficient found on median age in all years is consistent with the life cycle hypothesis that says an older person will demand more public goods than a

\footnotetext{
${ }^{23}$ To benefit the reader, the measure of publicness is shown in the tables in two ways. Because $\alpha$ was found to be close to 1 implying a more private good, we call $\alpha$ the "degree of privateness." The degree of publicness is thus expressed in both Tables 2.2 and 2.3 as 1- $\alpha$.

${ }^{24}$ See Bergstrom and Goodman (1973), Deno and Mehay (1987).
} 
Table 2.2 Cross-section K-12 Public Expenditure Estimates Excluding Cost Variables

\begin{tabular}{|c|c|c|c|}
\hline Independent variable & & Coefficient estimates & \\
\hline & $\begin{array}{c}\text { 1999-2000 } \\
\text { School Year }\end{array}$ & $\begin{array}{l}\text { 1989-1990 } \\
\text { School Year }\end{array}$ & $\begin{array}{l}\text { 1979-1980 } \\
\text { School Year }\end{array}$ \\
\hline Constant & $\begin{array}{c}-15.8703 * * \\
(5.2578)\end{array}$ & $\begin{array}{l}-3.5356 \\
(4.0029)\end{array}$ & $\begin{array}{c}-15.5461^{* *} \\
(4.7514)\end{array}$ \\
\hline Tax Share (TAX) & $\begin{array}{c}-0.1632 * * \\
(0.0534)\end{array}$ & $\begin{array}{c}-0.1939 * * * \\
(0.0589)\end{array}$ & $\begin{array}{l}-0.0524 \\
(0.0599)\end{array}$ \\
\hline Population (POP) & $\begin{array}{c}0.8146^{* * *} \\
(0.0582)\end{array}$ & $\begin{array}{c}0.8026^{* * * *} \\
(0.0372)\end{array}$ & $\begin{array}{l}0.9207 * * * \\
(0.0685)\end{array}$ \\
\hline $\begin{array}{l}\text { Disposable Income } \\
\text { (INCOME) }\end{array}$ & $\begin{array}{l}0.8190^{* *} \\
(0.2024)\end{array}$ & $\begin{array}{c}0.6554^{* * * *} \\
(0.1418)\end{array}$ & $\begin{array}{l}1.6198^{* * *} \\
(0.2170)\end{array}$ \\
\hline $\begin{array}{l}\text { Population Density } \\
\text { (DEN) }\end{array}$ & $\begin{array}{c}0.0302 \\
(0.0291)\end{array}$ & $\begin{array}{c}0.0306 \\
(0.0279)\end{array}$ & $\begin{array}{l}-0.0412 \\
(0.0345)\end{array}$ \\
\hline Median Age (AGE) & $\begin{array}{l}2.5112^{* *} \\
(0.7510)\end{array}$ & $\begin{array}{c}1.5947 \\
(1.0897)\end{array}$ & $\begin{array}{c}1.8224 \\
(1.2408)\end{array}$ \\
\hline Percent non-white (NW) & $\begin{array}{l}-0.0281 \\
(0.0393)\end{array}$ & $\begin{array}{c}-0.0620^{* *} \\
(0.0308)\end{array}$ & $\begin{array}{l}-0.0327 \\
(0.0288)\end{array}$ \\
\hline $\begin{array}{l}\text { Percent under } 18 \\
\text { (LESSTHAN18) }\end{array}$ & $\begin{array}{l}1.8970^{*} \\
(0.7464)\end{array}$ & $\begin{array}{c}1.0247 \\
(0.7564)\end{array}$ & $\begin{array}{c}0.6440 \\
(0.8602)\end{array}$ \\
\hline $\begin{array}{l}\text { Calculated Degree of } \\
\text { Publicness } \quad(1-\alpha)\end{array}$ & 0.0265 & 0.0044 & 0.0283 \\
\hline $\begin{array}{l}\text { Calculated Degree of } \\
\text { Privateness }(\alpha)\end{array}$ & 0.9735 & 0.9956 & 0.9717 \\
\hline Adjusted R-squared & 0.9788 & 0.9818 & 0.9758 \\
\hline F-statistic & 330.79 & 386.47 & 289.40 \\
\hline Observations & 51 & 51 & 51 \\
\hline
\end{tabular}

Notes. For the coefficient estimates, standard errors are in parentheses and the asterisks indicate significance as follows: $* * *=1 \%, * *=5 \%, *=10 \%$. The asterisks on calculated numbers represent the results from an F-test performed to determine whether $\alpha$ was significantly different than one and indicate significance as follows: $* * *=1 \%, * *=5 \%, *=10 \%$. 
younger person with the same tax share and income. ${ }^{25}$ Percent of the population nonwhite is found to be negative in all years and significant for 1989-90. The coefficient on percent of the population less than 18 is found to be positive for all three school years and statistically significant for 1999-2000.

Table 2.3 reports the results of equation (12) which takes into account possible cost differences across states. The degree of publicness is again measured and the findings reveal that education was approximately 78 percent private in $1999-00,80$ percent private in 1989-90 and 72 percent private in 1979-80. Although the degree of privateness falls in this specification, the percentages still imply that K-12 education is mostly a private good with few spillover benefits. The results also indicate that the change in this measure over the past three decades is minimal which is consistent with the findings from equation (11) when costs are excluded. In addition, the coefficients on population density (DEN), median age (AGE), percent non-white (NW), and percent under 18 (LESSTHAN18) are also all consistent with the results from equation (11). The coefficients on teacher salary (SALARY) and the number of schools (SCHOOLS) are positive and statistically significant for all three school years while the cost variable measuring the percent of students eligible for free or reduced lunch (FREELUNCH) is found to be insignificant in both the 1999-00 and 1989-90 regression equations.

\footnotetext{
${ }^{25}$ See Bergstrom and Goodman (1973) for further analysis of this finding.
} 
Table 2.3 Cross-section K-12 Public Expenditure Estimates Including Cost Variables

\begin{tabular}{|c|c|c|c|}
\hline Independent variable & & Coefficient estimates & \\
\hline & $\begin{array}{l}\text { 1999-2000 } \\
\text { School Year }\end{array}$ & $\begin{array}{l}\text { 1989-1990 } \\
\text { School Year }\end{array}$ & $\begin{array}{l}\text { 1979-1980 } \\
\text { School Year }\end{array}$ \\
\hline Constant & $\begin{array}{c}-10.4374 * * \\
(4.0772)\end{array}$ & $\begin{array}{c}-6.9874 * * \\
(3.5216)\end{array}$ & $\begin{array}{c}-14.3121^{* *} \\
(4.2851)\end{array}$ \\
\hline Tax Share (TAX) & $\begin{array}{l}-0.0037 \\
(0.0521)\end{array}$ & $\begin{array}{l}-0.1101^{*} \\
(0.0611)\end{array}$ & $\begin{array}{l}-0.0144 \\
(0.0444)\end{array}$ \\
\hline Population (POP) & $\begin{array}{c}0.7787 * * * \\
(0.0937)\end{array}$ & $\begin{array}{l}0.7160 * * * \\
(0.0770)\end{array}$ & $\begin{array}{l}0.7122 * * * \\
(0.0857)\end{array}$ \\
\hline $\begin{array}{l}\text { Disposable Income } \\
\text { (INCOME) }\end{array}$ & $\begin{array}{l}-0.1643 \\
(0.2309)\end{array}$ & $\begin{array}{c}0.2853 \\
(0.2289)\end{array}$ & $\begin{array}{l}0.8534 * * \\
(0.3639)\end{array}$ \\
\hline Population Density (DEN) & $\begin{array}{c}0.0161 \\
(0.0256)\end{array}$ & $\begin{array}{c}0.0322 \\
(0.0275)\end{array}$ & $\begin{array}{l}-0.0060 \\
(0.0262)\end{array}$ \\
\hline Median Age (AGE) & $\begin{array}{l}1.1965^{* *} \\
(0.6047)\end{array}$ & $\begin{array}{c}1.2783 \\
(0.9763)\end{array}$ & $\begin{array}{l}1.3793 \\
(1.1201)\end{array}$ \\
\hline Percent non-white (NW) & $\begin{array}{l}-0.0014 \\
(0.0307)\end{array}$ & $\begin{array}{l}-0.0296 \\
(0.0292)\end{array}$ & $\begin{array}{l}-0.0156 \\
(0.0271)\end{array}$ \\
\hline $\begin{array}{l}\text { Percent under } 18 \\
\text { (LESSTHAN18) }\end{array}$ & $\begin{array}{l}1.2561 * * \\
(0.5705)\end{array}$ & $\begin{array}{l}1.1808^{*} \\
(0.7033)\end{array}$ & $\begin{array}{c}0.5109 \\
(0.7729)\end{array}$ \\
\hline Teacher Salary (SALARY) & $\begin{array}{c}1.0553 * * * \\
(0.1867)\end{array}$ & $\begin{array}{l}0.7940 * * \\
(0.2762)\end{array}$ & $\begin{array}{l}0.7290 * * \\
(0.3108)\end{array}$ \\
\hline $\begin{array}{l}\text { Number of Schools } \\
\text { (SCHOOLS) }\end{array}$ & $\begin{array}{l}0.1868 * * \\
(0.0793)\end{array}$ & $\begin{array}{l}0.1628 * * \\
(0.0747)\end{array}$ & $\begin{array}{c}0.2832 * * * \\
(0.0866)\end{array}$ \\
\hline $\begin{array}{l}\text { Percent Free Lunch } \\
\text { (FREELUNCH) }\end{array}$ & $\begin{array}{c}0.2887 \\
(0.3207)\end{array}$ & $\begin{array}{l}-0.1298 \\
(0.2976)\end{array}$ & \\
\hline $\begin{array}{l}\text { Calculated Degree of } \\
\text { Publicness }(1-\alpha)\end{array}$ & 0.2185 & 0.1954 & 0.2775 \\
\hline $\begin{array}{l}\text { Calculated Degree of } \\
\text { Privateness }(\alpha)\end{array}$ & $0.7815^{* *}$ & $0.8046^{* *}$ & $0.7225^{* *}$ \\
\hline Adjusted R-squared & 0.9881 & 0.9865 & 0.9806 \\
\hline F-statistic & 414.80 & 365.66 & 281.53 \\
\hline Observations & 51 & 51 & 51 \\
\hline
\end{tabular}

Notes. For the coefficient estimates, standard errors are in parentheses and the asterisks indicate significance as follows: $* * *=1 \%, * *=5 \%, *=10 \%$. The asterisks on calculated numbers represent the results from an F-test performed to determine whether $\alpha$ was significantly different than one and indicate significance as follows: $* * *=1 \%$, $* *=5 \%, *=10 \%$. 


\subsection{Conclusion}

Traditionally government has played a large role in providing elementary and secondary public education in the United States. The results of this paper suggest that K-12 education is entirely, or almost entirely, a private good with little or no significant external benefits given the current equilibrium conditions. This finding substantially weakens the case for additional government involvement in the production of public education on efficiency grounds. ${ }^{26}$

The results of this paper also provide a good foundation for the likely impact of privatization efforts in education. The integration of school choice throughout the United States continues to grow through the creation of charter schools and the implementation of vouchers. This paper shows that when we look at efficiency measures, market forces are capable of producing the efficient quantity of education given the current amount of subsidization already in place and thus privatization has the potential to increase the current quality of education through effective competition. Opponents of using stronger market forces in education through school choice may still cite equity as a major concern, but as Toma (2001) argues, the lack of competition in the education market hurts the students of poor families the most since they are the ones who are forced to attend the often poor performing schools in their local neighborhoods.

Milton Friedman (1995) argues that substantial improvements in the current educational system will only occur if a significant fraction of our educational services are

\footnotetext{
${ }^{26}$ One should keep in mind that the outcome of this model is conditional on the current equilibrium. As mentioned previously, the results rely upon the positioning of the original private demand curve and the marginal cost curve. In addition, these results may not apply to many countries in the developing world. The external benefits created by educated individuals in developing countries may not fall to zero, implying that the spillover benefits could impact market efficiency. In addition, publicly provided education may be the only feasible solution to educating people in the developing world where the means for privatization at this time are basically nonexistent.
} 
rendered to individuals by private enterprise in order to provide effective competition for public schools. ${ }^{27}$ Perhaps this goal is somewhat daunting considering the large role government has played in the past providing education, but when one looks at the changes that have occurred because of school choice in the past few years, it is easy to see that competition has integrated itself into this market and has continued to be a source of controversy among policy makers.

The results of this paper help to settle some of the debate on the extent to which education suffers from a market failure based on the positive externality or spillover argument. At the margin, education does not produce additional Pareto-relevant spillover benefits and therefore, additional government intervention in the production of K-12 education cannot be justified on efficiency grounds. With this in mind, it is important to note that the privatization of education, or the continued efforts of school choice, would not face efficiency issues given the current equilibrium situation. One could also speculate that the current problems embedded within K-12 education are manifested by the presence of government failures which would be corrected for if privatization and further school choice options become more widely available.

When the public sector produces K-12 education, a good that has been shown to more closely fit the definition of a private good, there is no reason to expect the public sector to outperform the private sector in this market. Stronger market forces through school choice implements the much needed element of competition into the education market and thus brings with it all of the benefits that competition creates. In this case, higher quality K-12 education for all students would result.

\footnotetext{
${ }^{27}$ These ideas were printed in the Washington Post on February 19, 1995 and reprinted by the Cato Institute as Briefing Paper No. 23, June 23, 1995.
} 


\section{Chapter 3}

\section{The History of School Choice in the United States}

\subsection{Introduction}

The exact point in time from which to begin an analysis of the history of school choice in the United States varies with the definition one gives such an idea. The notion of implementing choice and competition in education can be traced all the way back to Adam Smith. The following is an excerpt from, An Inquiry Into the Nature and Causes of the Wealth of Nations, 1776 (Book 5, Chapter 1, Article 2).

\footnotetext{
The expense of the institutions for education and religions instruction, is likewise, no doubt, beneficial to the whole society, and may, therefore, without injustice, be defrayed by the general contribution of the whole society. This expense, however, might perhaps with equal propriety, and even with some advantage, be defrayed altogether by those who receive the immediate benefit of such education and instruction, or by the voluntary contribution of those who think they have occasion for either the one or the other.
}

Smith continues to point out in this chapter that the incentives of Professor's who receive money from a general fund rather than on a per student basis will lack motivation and incentive. Allowing students to choose the Professors under which to study creates an atmosphere where the Professor must compete for students by creating a reputation for providing high quality instruction. This idea of empowering students (or parents) to have a choice in the type of education that they receive creates an education market where competition can thrive. Consequently, this is the same motivation that has spurred the school choice movement in the United States over the past decade.

In 1983 the National Commission on Excellence in Education published an alarming federal report entitled $A$ Nation at Risk: The Imperatives for Educational Reform. After studying the American education system, the Commission found that 
American students were not performing at an acceptable level. This report also warned that if the United States did not make immediate attempts to remedy the situation by finding a solution to this problem, society would face dire consequences. ${ }^{28}$ The publication of $A$ Nation at Risk made education reform a permanent issue on the national agenda and opened the door for school choice to become one of the possible solutions to the problems facing our failing school systems.

\subsection{Charter Schools}

Charter schools are a form of school choice which has grown in popularity since the first charter school legislation was enacted in 1991. The first charter school opened in Minnesota in 1992, and since then, the number of charter schools has climbed to nearly 3,000 and the number of students enrolled has reached close to 700,000 for children in grades $\mathrm{K}-12 .^{29}$

The charter school movement began from a variety of other reform ideas such as alternative schools, magnet schools, privatization, and parental empowerment. The term "charter" may have originated in the 1970s when New England educator Ray Budde suggested that small groups of teachers be given contracts or "charters" by their local school boards to explore innovative approaches to education. ${ }^{30}$ Philadelphia started a number of schools in the late 1980s which were mostly schools of choice. Minnesota was the next place this idea began to take shape where charter schools were developed

\footnotetext{
${ }^{28}$ National Commission on Excellence in Education, 1983. A Nation at Risk: The Imperatives for Educational Reform Washington, D.C.: U.S. Department of Education.

${ }^{29}$ The Center for Education Reform, 2005. [Online] Available at URL http://www.edreform.com.

${ }^{30}$ WestEd, 1997. About the Charter School Movement, History [Online]. Available at URL http://www.uscharterschools.org/pub/uscs_docs/o/history.htm.
} 
based on three values: opportunity, choice, and responsibility for results. ${ }^{31}$ It is from here in the early nineties that the charter school movement truly began.

USCharterSchools.org is an online resource dedicated to providing information for those interested in learning more about the charter school movement. This site defines charter schools as follows:

\begin{abstract}
A charter school is a nonsectarian public school of choice that operates with freedom from many of the regulations that apply to traditional public schools. The "charter" establishing each such school is a performance contract detailing the school's mission, program, goals, students served, methods of assessment, and ways to measure success. The length of time for which charters are granted varies, but most are granted for 3-5 years. At the end of the term, the entity granting the charter may renew the school's contract. Charter schools are accountable to their sponsor-usually a state or local school board-to produce positive academic results and adhere to the charter contract. The basic concept of charter schools is that they exercise increased autonomy in return for this accountability. They are accountable for both academic results and fiscal practices to several groups: the sponsor that grants them, the parents who choose them, and the public that funds them. ${ }^{32}$
\end{abstract}

Charter school laws vary from state to state but typically cover some basic legal areas. $^{33}$ First, all states contain regulations on who may propose a charter, how charters are granted, and the number of charter schools allowed. In addition, states identify how the school is legally defined and the levels and types of finance that will be provided for operation. Rules regarding admissions and staff rights and privileges can also be found in state laws. Finally all states address the degree of control a charter school has over the development of its instructional goals and practices and the types of assessments that each charter school will face in regards to renewal of the contract. ${ }^{34}$

\footnotetext{
${ }^{31}$ Ibid.

${ }^{32} \mathrm{Ibid}$.

${ }^{33}$ The Center for Education Reform has developed a ranking of charter state laws according to a list of criteria such as the number of schools allowed, fiscal autonomy, automatic waiver from state and district laws, etc. The ranking gives a grade of A-F and ranks state laws as strong to medium if they receive a grade of A or B, and weak if they receive a grade of C, D or F. States with strong to medium strength laws are as follows: AZ, CA, CO, DE, FL, IN, MA, MI, MN, MO, NJ, NM, NY, NC, OH, OR, PA, TX, Washington, DC, WI. States with weak laws are as follows: AK, AR, CT, GA, HI, ID, IL, IA, KS, LA, MD, MS, NV, NH, OK, RI, SC, TN, UT, VA, WY.

${ }^{34}$ Ibid.
} 
Charter schools are not allowed to charge tuition and they are funded according to enrollment. In some states, such as Alaska, Colorado, Minnesota, and New Jersey, they receive less than $100 \%$ of the funds allocated to the traditional public schools. In other states, like California, additional funds or loans are made available to them. ${ }^{35}$ In most states, charters do not receive capital funds for facilities but federal legislation provides grants to help charters with start-up costs. They are also entitled to federal categorical funding for which their students are eligible, such as Title I and Special Education monies.

As of 2005, 41 states, including the District of Columbia, have passed charter school laws. ${ }^{36}$ The states are listed in Table 3.1 which includes the year the charter law was passed, the year the law was amended, the current number of schools, and the number of students enrolled.

\subsection{Vouchers}

The next form of school choice that I will discuss is probably the most controversial of four types mentioned in this chapter. This school choice option allows the use of public money to attend private nonparochial and parochial schools through the use of a voucher. Milton Friedman is most commonly cited as the first person to develop the idea of educational vouchers. ${ }^{37}$ Friedman (1963) stated that "governments could require a minimum level of schooling financed by giving parents vouchers redeemable for a specified maximum sum per child per year if spent on 'approved' educational services."

\footnotetext{
${ }^{35}$ Ibid.

${ }^{36}$ Ibid.

${ }^{37}$ As I will mention later on, Vermont and Maine have been implementing a voucher type program since the late 1800 s.
} 
Table 3.1 Charter School Numbers by State as of January 2005

\begin{tabular}{|c|c|c|c|c|}
\hline State & Year Law Passed & Year Law Amended & Schools Operating & Enrollment \\
\hline Alaska & 1995 & 2001 & 20 & 2,682 \\
\hline Arizona & 1994 & 2001 & 491 & 73,542 \\
\hline Arkansas & 1995 & 2003 & 11 & 1,486 \\
\hline California & 1992 & No amendments & 500 & 153,935 \\
\hline Colorado & 1993 & 2003 & 93 & 25,512 \\
\hline Connecticut & 1996 & 2001 & 16 & 2,526 \\
\hline Delaware & 1995 & 2001 & 13 & 5,262 \\
\hline Florida & 1996 & 2002 & 258 & 53,350 \\
\hline Georgia & 1993 & No amendments & 36 & 15,117 \\
\hline Hawaii & 1994 & 2002 & 26 & 3,301 \\
\hline Idaho & 1998 & 2002 & 13 & 2,694 \\
\hline Illinois & 1996 & 2003 & 30 & 10,309 \\
\hline Indiana & 2001 & 2001 & 17 & 1,275 \\
\hline Iowa & 2002 & 2003 & 0 & 0 \\
\hline Kansas & 1994 & 2003 & 31 & 2,568 \\
\hline Louisiana & 1995 & No amendments & 16 & 4,631 \\
\hline Maryland & 2003 & 2000 & 0 & 0 \\
\hline Massachusetts & 1993 & No amendments & 50 & 14,013 \\
\hline Michigan & 1993 & 2001 & 210 & 60,236 \\
\hline Minnesota & 1991 & No amendments & 95 & 12,269 \\
\hline Mississippi & 1997 & No amendments & 1 & 334 \\
\hline Missouri & 1998 & 2000 & 27 & 12,130 \\
\hline Nevada & 1997 & 2003 & 14 & 2,851 \\
\hline New Hampshire & 1995 & 2001 & 0 & 0 \\
\hline New Jersey & 1996 & 2001 & 52 & 18,081 \\
\hline New Mexico & 1993 & No amendments & 37 & 4,234 \\
\hline New York & 1998 & No amendments & 51 & 10,954 \\
\hline North Carolina & 1996 & No amendments & 94 & 21,030 \\
\hline Ohio & 1997 & 2001 & 142 & 28,446 \\
\hline Oklahoma & 1999 & 2003 & 12 & 2,197 \\
\hline Oregon & 1999 & 2002 & 43 & 2,107 \\
\hline Pennsylvania & 1997 & 2001 & 103 & 33,656 \\
\hline Rhode Island & 1995 & 2002 & 8 & 914 \\
\hline South Carolina & 1996 & 1998 & 19 & 1,235 \\
\hline Tennessee & 2002 & No amendments & 4 & 0 \\
\hline Texas & 1995 & 2002 & 241 & 74,129 \\
\hline Utah & 1998 & No amendments & 19 & 1,259 \\
\hline Virginia & 1998 & 2001 & 9 & 1,440 \\
\hline Washington, DC & 1996 & 2002 & 43 & 11,530 \\
\hline Wisconsin & 1993 & No amendments & 147 & 26,797 \\
\hline Wyoming & 1995 & 2002 & 1 & 110 \\
\hline
\end{tabular}

Source: The Center For Education Reform, 2005, http://www.edreform.com. 
Friedman wanted to limit the government's role in education to making sure that schools met minimum educational standards. In his view, an educational market would be much more efficient at allocating educational resources than a system of schools run by the government.

Initially, Friedman's ideas did not get much public support but in the 1960's President Johnson's Office of Economic Opportunity (OEO) developed a voucher proposal which was embraced by President Richard Nixon's administration. There was so little enthusiasm for the idea, however, that Minneapolis, Rochester, Kansas City, Milwaukee, Gary, and Seattle all rejected the opportunity to participate in an experimental program. ${ }^{38}$ The only community that agreed to try the OEO plan was Alum Rock, California, where it was implemented within the public school system with disappointing results and subsequently abandoned. ${ }^{39}$

In 1971, the Panel on Non-Public Education of the Nixon administration's Presidential Commission on School Finance wanted to develop a plan for the public funding of religious schools. The plan was referred to as "Parochiaid" and faced the possibility of being deemed unconstitutional as well as widespread public opposition. The Supreme Court in its 8-0 ruling in Lemon v. Kurtzman in 1971 held that to be constitutional the plan had to meet three standards: its purpose is not secular; its main effect is to neither advance nor inhibit religion; and it does not excessively entangle the state with religion. ${ }^{40}$

\footnotetext{
${ }^{38}$ Molnar, Alex, 2001. "School Vouchers: The Law, the Research, and Public Policy Implications." ${ }^{39}$ Ibid.

${ }^{40}$ Thomas W. Lyons, 1970. "Parochiaid? Yes!" Educational Leadership, November 1971, pp. 102-104, and Glenn L. Archer, "Parochiaid? No!" Educational Leadership, November 1971, pp. 105-107. See also, Grace Graham, "Can the Public School Survive Another Ten Years?" Educational Leadership, pp. 800803.
} 
The Reagan administration tried repeatedly in 1983, 1985, and 1986 to get some form of voucher legislation passed but was unsuccessful in all attempts. In the late 1980 's and early 1990's, supporters of private school voucher plans made an important breakthrough by effectively blurring the distinction between public school choice and private school voucher plans in the public debate. ${ }^{41}$ This eventually led to where we stand today with a few pilot voucher programs underway.

Currently there are two types of vouchers operating in the United States: publicly funded and privately funded. As defined by the Education Commission of the States (ECS), a publicly funded voucher is a payment made to a parent, or to an institution on the parent's behalf, to be used for a child's education expenses. For example, vouchers have been used in the District of Columbia and Florida to help the plight of low performing schools, in Cleveland, Ohio and Milwaukee, Wisconsin to aid low income families, and in Maine and Vermont to provide students without a school in their town an opportunity to be educated elsewhere.

A privately funded voucher is a payment that a private organization makes to a parent, or an institution on a parent's behalf, to be used for a child's education expenses. ${ }^{42}$ Although not as common as the publicly funded voucher, two of the more notable privately funded efforts are the Children First America (CFA) and the Children's Scholarship Fund (CSF). In 1994, CFA was established with the purpose of establishing privately funded vouchers across the United States. Currently CFA is affiliated with over 100 privately funded voucher systems in 39 states including the District of Columbia. In 1998, the Children's Scholarship Fund (CSF) was developed by New York City investor

\footnotetext{
${ }^{41}$ Molnar, Alex, 2001. "School Vouchers: The Law, the Research, and Public Policy Implications."

${ }^{42}$ Education Commission of the States, 2005. [Online] Available at URL http://www.ecs.org.
} 
Theodore J. Forstmann and Wal-Mart heir John Walton by pledging \$100 million dollars to help low-income parents send their children to private and parochial schools. ${ }^{43}$ In April 1999, CSF announced that 1,237,360 children applied for partial scholarships, which amounts to about one out of every 50 schoolchildren in the country. ${ }^{44}$ As of June 2002, CSF was giving scholarships to nearly 34,000 children across the country. ${ }^{45}$

Most people are not aware that a type of voucher program has been in existence for over a century. In Maine since 1869 and in Vermont since 1873, vouchers have been in use through "town tuitioning" programs, which serve students living in rural and nonurban areas in these two states. This voucher-like system was created to serve the needs of local families who resided in districts where elementary and secondary schools were nonexistent. Funds were, and still are, provided by the student's home district to send the child to any public or non-sectarian private school anywhere within and even outside the state.

The Milwaukee Parental Choice Program (MPCP) is probably the most studied public voucher program in the United States. It was sponsored in 1990 by AfricanAmerican State Representative Polly Williams in response to high drop-out rates, disgraceful test scores and an unacceptable disparity in educational opportunity between Milwaukee's low-income and middle-income families.

MCPC provides an opportunity for students under specific circumstances to attend at no charge, private sectarian and nonsectarian schools located in the city of

\footnotetext{
43 Ibid.

${ }^{44}$ Anemona Hartocollis, 1999. "Private School Choice Plan Draws a Million Aid-Seekers," The New York Times, (21 April 1999), A1, A25.

${ }^{45}$ Children's Scholarship Fund, About CSF: Facts, 2005. [Online] Available at URL http://www.scholarshipfund.org/about/facts.asp.
} 
Milwaukee. $^{46}$ Students in the program must come from households with income 1.75 times the poverty line or less and may not have been in private schools or in school districts other than the Milwaukee Public School (MPS) District in the prior year. ${ }^{47}$ At first, eligible schools had to be private, nonsectarian schools with no religious affiliation or training. In 1995, to meet high demand, Wisconsin approved the inclusion of religious schools in the Milwaukee Choice Program but due to a legal challenge, religious schools were not allowed to participate until $1998{ }^{48}$ Participating private schools receive the Milwaukee Public School per-member state-aid in place of tuition for students in the program.

In addition, schools cannot discriminate in selection based on race, religion, gender, prior achievement, or prior behavioral records and if classes are oversubscribed, selection is on a random basis. Schools must meet at least one standard established for attendance, parental involvement, student achievement on standardized tests, or grade progress. The total number of students in the Choice Program in any year is limited to 1.5 percent of the students in the Milwaukee Public Schools. ${ }^{49}$

Research on choice students and families indicates that choice is targeted toward poor families attempting to find an alternative to what they view as a poor educational environment for their children. The choice students come from poor, mostly single-parent households and like Milwaukee Public School (MPS) parents, approximately 60 percent are receiving Aid to Families with Dependent Children or public assistance. The parents

\footnotetext{
${ }^{46}$ The Data and Program Library Service (DPLS) is the central repository of data collections used by the social science research community at the University of Wisconsin-Madison and provides information about MCPC for research purposes. The characteristics of MCPC were found on their website, available at URL http://dpls.dacc.wisc.edu/dpls_mission.html.

${ }^{47}$ Ibid.

${ }^{48}$ Ibid.

${ }^{49}$ Ibid.
} 
also are found to be dissatisfied with prior public schools, and, based on prior test scores, there is clear evidence that their children were not doing well in those schools.

According to DPLS, despite being poor, however, the choice families are smaller than those in the comparison groups, thus providing an opportunity for parents to focus more on any single child. The parents (especially mothers) have been found to be more educated, more likely to work at home with their children on education problems, and were more likely to participate in their children's prior schools at higher rates than the average parent. Table 3.2 lists the number of students participating in the program from its infancy through the 2003-04 school year.

In addition to the MPCP, the Cleveland Scholarship program was the first publicly funded American voucher program to include both parochial and secular schools. On June 30, 1995, then-Governor and former Cleveland Mayor George Voinovich signed a state budget bill that included a pilot voucher program for Cleveland students. Beginning in the 1996-97 school year, the state provided vouchers worth up to $\$ 2,250$ to 1,994 low-income students in grades K-3 to attend the public or private school of their choice. The voucher program went through some legal turmoil when the constitutionality of including religious schools was brought into question. After being deemed unconstitutional in December of 2000 proponents sought to get the decision overturned by The Court of Appeals for the Sixth Circuit. In March 2001, the U.S. Court of Appeals declined to review the lower panel's ruling. In June 2002, the U.S. Supreme Court decision in Zelman v. Simmons-Harris upheld the Cleveland Scholarship and Tutoring Program, ruling that the use of public money to underwrite tuition at private and religious schools does not violate the Establishment Clause of the Constitution as long as 
Table 3.2 Voucher Program Student Enrollment

\begin{tabular}{|l|l|l|l|l|}
\hline & Milwaukee & Cleveland & Florida McKay & Florida OSP \\
\hline $1990-91$ & 341 & & & \\
\hline $1991-92$ & 521 & & & \\
\hline $1992-93$ & 608 & & & \\
\hline $1993-94$ & 733 & & & \\
\hline $1994-95$ & 802 & & & \\
\hline $1995-96$ & 1,454 & & & \\
\hline $1996-97$ & 1,657 & 1,994 & & \\
\hline $1997-98$ & 1,545 & 2,914 & & \\
\hline $1998-99$ & 6,085 & 3,674 & & \\
\hline $1999-00$ & 8,007 & 3,406 & Pilot Year & 57 \\
\hline $2000-01$ & 9,619 & 3,797 & 977 & 41 \\
\hline $2001-02$ & 10,882 & 4,523 & 5,017 & 46 \\
\hline $2002-03$ & 11,670 & 5,281 & 9,105 & 555 \\
\hline $2003-04$ & 13,268 & 5,887 & 12,456 & 633 \\
\hline
\end{tabular}

Source: Wisconsin Department of Public Instruction, the Ohio Department of Education's Office of Cleveland Scholarship and Tutoring Program, and the Florida Department of Education.

parents make the decision regarding where the voucher is used. Today, the Cleveland Scholarship and Tutoring Program provides tuition vouchers to parents who send their children to a public or private, religious or nonreligious school of their choice and allows public school parents to purchase tutoring services for their children. Students must reside in Cleveland and be in grades $\mathrm{K}-3$ to enter the program but eligibility remains through grade 10. The voucher is based on a percentage of the tuition, 90-75 percent based on income level, or $\$ 3,000$, whichever is lower and parents must pay the 
difference. Students are accepted on a random basis with siblings of current participants given priority. ${ }^{50}$ Table 2 lists the number of students participating in the program from its beginning in 1996 through the 2003-04 school year.

Florida has three main programs that allow students to attend private or religious schools with taxpayer dollars. The pilot year for the McKay Scholarships was 1999 which allows students with disabilities to receive a McKay voucher after being in public school for a year. McKay vouchers can be worth more than $\$ 20,000$, depending on the severity of the student's disability. ${ }^{51}$

The Opportunity Scholarship, also starting in 1999, allows students in public schools that receive an $\mathrm{F}$ grade twice in four years to receive a voucher to attend a private or public school. This scholarship is a part of Governor Jeb Bush's A+ plan for education and combines the use of vouchers with high-stakes testing. Students enrolled in grades 310 take the state's accountability test, the Florida Comprehensive Assessment Test (FCAT). Students must pass the reading portion of the FCAT in order to be promoted to the 4 th grade and must pass the 10th grade test in order to graduate. The results of the test are also used to grade schools on a scale from A to F and as mentioned above, if a school receives an F twice in any four-year period, it is considered chronically failing and its students become eligible to receive vouchers they can use at other public schools or at private schools. Going into the 2002-03 administration of the FCAT, 129 schools had received at least one $\mathrm{F}$ and ten schools have had their students become eligible for

\footnotetext{
${ }^{50}$ Facts and figures were taken from the following source: http://www.heritage.org/Research/Education/Schools/ohio.cfm.

${ }^{51}$ The Palm Beach Post, 2003. [Online] Available at URL http://www.palmbeachpost.com.
} 
vouchers since school grading based on the FCAT began in the $1998-99$ school year. $^{52}$ Opportunity Scholarships are currently being challenged in court because of their use of tax dollars at religious schools. ${ }^{53}$ Table 2 lists the number of students participating in the McKay and Opportunity Scholarship program from its beginning in 1999 through the 2003-04 school year.

The Corporate Tax Credit Scholarship is the third type of program in which students who receive free or reduced-price lunches are eligible for vouchers worth $\$ 3,500$ each. Private companies can donate up to a total of $\$ 88$ million dollars to the program and receive a dollar-for-dollar tax credit. The vouchers are awarded through private Scholarship Funding Organizations that collect the donations and issue the vouchers to students. There are currently about 10,420 students in Florida using tax credit vouchers. ${ }^{54}$

On January 22, 2004, Congress passed a federally funded school voucher program, allocating \$14 million dollars to establish a program for low-income students in the District of Columbia. ${ }^{55}$ The funding is part of the Fiscal 2004 Omnibus Spending bill that passed the Senate by a vote of 65 to 28 and was subsequently signed by the president. Under this program, for five years beginning with the 2004-05 school year, federal taxpayers will subsidize the tuition of low-income students in the District of Columbia who can gain admittance to religious and other private schools, up to a maximum of $\$ 7,500$ per year per student. ${ }^{56}$ The voucher program is being run by the

\footnotetext{
${ }^{52}$ Greene, Jay P. and Marcus A. Winters, 2003. Education Working Paper 2, [Online] Available at URL $\mathrm{http} / / / \mathrm{www}$.manhattan-institute.org.

${ }^{53}$ The Florida Supreme Court will listen to oral arguments on June 7, 2005.

${ }_{55}^{54}$ The Palm Beach Post, [Online] Available at URL http://www.palmbeachpost.com.

${ }^{55}$ People for the American Way Foundation, [Online] Available at URL http://www.pfaw.org. Eligible students are those whose families earn up to 185 percent of the poverty level.

${ }^{56}$ Ibid.
} 
U.S. Department of Education, along with the Mayor of the District of Columbia, and administered by a private organization called the Washington Scholarship Fund. ${ }^{57}$

Many critics of the D.C. voucher law have voiced their concerns about how it has been implemented. For instance, even though the voucher program was meant to allow low-income students in failing public schools to leave those schools and attend higherperforming schools, there is no criteria that gives the private schools participating any rules to follow in order to demonstrate that they are higher performing. In addition, the law does not prohibit private schools from imposing admissions tests or other admissions requirements on voucher students, or from charging them tuition in excess of the maximum voucher amount if their tuition rates are higher.

While it is still too early to evaluate how the program is working in terms of student outcomes, one problem area has already came into view. Although the voucher law gives the greatest priority to students attending D.C. public schools most in need of improvement as defined by federal law, research shows that fewer than 75 of the more than 1,300 students who received vouchers came from those public schools. At the same time, more than 200 students already enrolled in private schools, almost three times that number, have received vouchers. ${ }^{58}$ Future research on this program should focus on how to best reach those students who would benefit the most from switching schools.

\subsection{Open Enrollment}

Even though some voucher programs managed to take shape and are still fighting their way through legislation today, the Reagan administration, meeting with opposition to the

\footnotetext{
${ }^{57}$ Ibid.

${ }^{58}$ Ibid.
} 
free market ideas that private vouchers created, had decided to move on to the concept of public school choice in order to gain support. Many saw this new idea for public school choice as a strategy to reform rather than dismantle the entire educational system. In 1988 Minnesota enacted a public school choice law and over the next eight years, 13 other states followed suit with laws allowing students to attend any public school in the state that had room for them. ${ }^{59}$ This type of school choice is known as open enrollment and became even more important when The Education Reform Act of 1993 required that districts vote yearly on whether to accept choice students. Open enrollment laws are defined in the following way: "intradistrict" open enrollment laws allow choice of public schools within district boundaries, "interdistrict" open enrollment laws allow choice of public schools across district boundaries, "mandatory" open enrollment laws require districts to allow students to transfer to the school of their choice and "voluntary" open enrollment laws allow districts to choose whether to allow students to transfer to the school of their choice. State aid normally follows the students to the new school districts, and parents generally are responsible for transporting their children to the boundaries of the new school districts. However, in some states, low-income families receive some transportation support. Table 3.3 lists the status of the open enrollment laws in the United States as of December 2002.

\footnotetext{
${ }^{59}$ Ibid.
} 
Table 3.3 Open Enrollment Laws in the United States as of December 2002

\begin{tabular}{|c|c|c|c|c|}
\hline State & $\begin{array}{l}\text { Interdistrict } \\
\text { Mandatory }\end{array}$ & $\begin{array}{l}\text { Interdistrict } \\
\text { Voluntary } \\
\end{array}$ & $\begin{array}{l}\text { Intradistrict } \\
\text { Mandatory } \\
\end{array}$ & $\begin{array}{l}\text { Intradistrict } \\
\text { Voluntary }\end{array}$ \\
\hline Alaska & & & $\mathrm{X}$ & \\
\hline \multicolumn{5}{|l|}{ Arkansas } \\
\hline Arizona & $X$ & & $\mathrm{X}$ & \\
\hline \multicolumn{5}{|l|}{ Alabama } \\
\hline California & & $\mathrm{X}$ & $\mathrm{X}$ & \\
\hline Colorado & $\mathrm{X}$ & $\mathrm{X}$ & $\mathrm{X}$ & \\
\hline Connecticut & $\mathrm{X}$ & $\mathrm{X}$ & & $\mathrm{X}$ \\
\hline Delaware & $\mathrm{X}$ & & $\mathrm{X}$ & \\
\hline \multicolumn{5}{|l|}{$\begin{array}{l}\text { District of } \\
\text { Columbia }\end{array}$} \\
\hline Florida & & $\mathrm{X}$ & $\mathrm{X}$ & \\
\hline Georgia & $\mathrm{X}$ & $\mathrm{X}$ & $\mathrm{X}$ & \\
\hline Hawaii & & & & $\mathrm{X}$ \\
\hline Idaho & & $\mathrm{X}$ & & $\mathrm{X}$ \\
\hline Illinois & & & $\mathrm{X}$ & \\
\hline Indiana & & $\mathrm{X}$ & $\mathrm{X}$ & \\
\hline Iowa & $\mathrm{X}$ & & & \\
\hline Kansas & & $\mathrm{X}$ & & \\
\hline Kentucky & $\mathrm{X}$ & & $\mathrm{X}$ & \\
\hline Louisiana & $\mathrm{X}$ & $\mathrm{X}$ & $\mathrm{X}$ & \\
\hline Maine & & $\mathrm{X}$ & & \\
\hline \multicolumn{5}{|l|}{ Maryland } \\
\hline Massachusetts & & $\mathrm{X}$ & $\mathrm{X}$ & \\
\hline Michigan & & $\mathrm{X}$ & & \\
\hline Minnesota & $\mathrm{X}$ & & & \\
\hline Mississippi & & $\mathrm{X}$ & & \\
\hline Missouri & $\mathrm{X}$ & $\mathrm{X}$ & & \\
\hline Montana & $\mathrm{X}$ & $\mathrm{X}$ & & \\
\hline Nebraska & $\mathrm{X}$ & & & \\
\hline Nevada & & $\mathrm{X}$ & & \\
\hline New Hampshire & & $\mathrm{X}$ & & $\mathrm{X}$ \\
\hline New Jersey & & $\mathrm{X}$ & & \\
\hline New Mexico & & $\mathrm{X}$ & & $X$ \\
\hline New York & & $\mathrm{X}$ & & \\
\hline \multicolumn{5}{|l|}{ North Carolina } \\
\hline North Dakota & & $\mathrm{X}$ & & \\
\hline Ohio & & $\mathrm{X}$ & $\mathrm{X}$ & \\
\hline Oklahoma & $\mathrm{X}$ & & $\mathrm{X}$ & \\
\hline Oregon & & $\mathrm{X}$ & & \\
\hline Pennsylvania & & $\mathrm{X}$ & & \\
\hline Rhode Island & & $\mathrm{X}$ & & \\
\hline South Carolina & & $\mathrm{X}$ & & \\
\hline South Dakota & $\mathrm{X}$ & & $\mathrm{X}$ & \\
\hline Tennessee & & $\mathrm{X}$ & $\mathrm{X}$ & $\mathrm{X}$ \\
\hline Texas & & $\mathrm{X}$ & $\mathrm{X}$ & $\mathrm{X}$ \\
\hline Utah & $\mathrm{X}$ & & $\mathrm{X}$ & \\
\hline Vermont & & $\mathrm{X}$ & & \\
\hline \multicolumn{5}{|l|}{ Virginia } \\
\hline Washington & $\mathrm{X}$ & & $\mathrm{X}$ & \\
\hline West Virginia & & $\mathrm{X}$ & $\mathrm{X}$ & $\mathrm{X}$ \\
\hline Wisconsin & $\mathrm{X}$ & $\mathrm{X}$ & $\mathrm{X}$ & \\
\hline Wyoming & & $\mathrm{X}$ & & \\
\hline
\end{tabular}

Source: Education Commission of the States, 2005. [Online] Available at URL http://www.ecs.org. 


\subsection{Tax Credit and Tax Deduction Programs}

The final type of school choice that I will discuss is tax credit and tax deduction programs. Table 3.4 lists the seven states that currently offer these options and the year in which the program was enacted.

Table 3.4 Tax Credit and Deduction Programs

\begin{tabular}{|l|l|}
\hline State & Year Law Passed \\
\hline Arizona & 1998 \\
\hline Florida & 2002 \\
\hline Illinois & 1999 \\
\hline Iowa & 1987 \\
\hline Minnesota & $1955 / 1998^{60}$ \\
\hline Pennsylvania & 2001 \\
\hline
\end{tabular}

Source: http://www.schoolchoiceinfo.org.

Educational tax credits are a direct reduction in tax liability for educational expenditures such as tutoring, books, computers, and, in some states, private school tuition. ${ }^{61}$ For example, if an individual owes $\$ 1,000$ in income taxes, she is eligible for a given state's $\$ 500$ tax credit. This person would then subtract the $\$ 500$ tax credit from the $\$ 1,000$ tax liability, and then owe $\$ 500$ in income taxes. ${ }^{62}$ State legislation determines the amount of credit and which educational expenses qualify. In some states, families

\footnotetext{
${ }^{60}$ Minnesota's income tax features both an education tax credit and a deduction program. The deduction has been in effect since 1955 and allows parents earning more than $\$ 37,500$ to subtract from their taxable income up to $\$ 1,625$ per qualifying child in grades K-6, and $\$ 2,500$ for a qualifying child in grades 7-12. The education tax credit, which first took effect in 1998 , is available to families earning less than $\$ 37,500$ and is worth up to $\$ 1,000$ per child and $\$ 2,000$ per family. The credit is limited to 75 percent of the taxpayer's qualifying expenses. This means that for each dollar spent on a qualifying educational expense for a qualifying child, taxpayers receive 75 cents as a tax credit on their income tax return. While the deduction lowers taxable income, the education credit reduces state income tax liability or increases a taxpayer's refund. Source: School Choice Info, 2002. [Online] Available at URL

http://www.schoolchoiceinfo.org.

${ }^{61}$ School Choice Info, 2002. [Online] Available at URL http://www.schoolchoiceinfo.org.

${ }^{62}$ Education Commission of the States, 2005. [Online] Available at URL http://www.ecs.org.
} 
with no tax liability may receive a refund for part of, or the entire amount spent on qualifying educational expenses.

Educational tax deductions allow for certain educational expenses to be deducted from taxable income prior to the calculation of tax liability. ${ }^{63} \mathrm{~A}$ tax deduction offsets a portion of the cost of qualifying educational expenses, depending on the percentage tax bracket an individual is in. For instance, suppose an individual has a taxable income of $\$ 100,000$. She, however, is eligible for a given state's $\$ 1,500$ tax deduction. She subtracts the $\$ 1,500$ from her income of $\$ 100,000$, and now has $\$ 98,500$ in taxable income. ${ }^{64}$ Families with no tax liability will receive no benefits from this type of program.

\subsection{Conclusion}

Although private schools have always been an option for parents when it comes to choosing a school for their children, it was intentionally left out of this discussion. The school choice options that I focus on are the ones available to all families regardless of ability to pay. In the past, it was only wealthy families who could afford to send their children to private schools, thus traditionally having more educational options, but over the past two decades, school choice proponents have worked to break through these barriers.

Currently school choice is probably the most referenced idea when education reform is the topic of debate. The speed with which school choice has evolved over the past couple of decades may be too slow for some who feel that competition is the only means for improving our current system. However, one can definitely see that a school

\footnotetext{
${ }^{63}$ School Choice Info, 2002. Online] Available at URL http://www.schoolchoiceinfo.org.

${ }^{64}$ Education Commission of the States, 2005. [Online] Available at URL http://www.ecs.org.
} 
choice movement has taken shape and its future will most likely depend on how fast we can learn from past mistakes and continue to develop successes. 


\section{Chapter 4}

\section{Charter Schools in Arizona: Does Being a For-Profit Institution Make a Difference?*}

\subsection{Introduction}

School choice as a method for improving educational outcomes has become an increasingly important topic among policy makers over the last decade. One existing hypothesis states that school choice creates an atmosphere of competition for students that will spur public schools to higher achievement. A study by Teske, Schneider, Buckley, and Clark (2000) shows that school managers respond to competition from other schools by trying harder to enhance school efficiency and by adopting more innovations at their school in direct proportion to the competitive enrollment pressure that they feel.

Charter schools as a type of school choice have been growing in popularity over the past several years. The effects of charter schools on traditional public schools have been widely studied and much of the evidence points to gains in productivity in public schools that are created by the competition that school choice generates. Hoxby (2003) found that Arizona public schools raised their productivity in response to competition from charter schools by 0.55 (national percentile points per thousand dollars spent) based on the fourth-grade reading exam, by 0.70 based on the fourth-grade mathematics exam, by 0.38 based on the seventh-grade reading exam, and by 0.53 based on the seventhgrade mathematics exam. In another study, Holmes, Desimone, and Rupp (2003) found an approximate one percent increase in achievement when traditional schools in North Carolina faced competition from a charter school. 
The literature has also focused on comparing charter students to traditional public school students to determine the impact of the resulting competition on student achievement levels. The first randomization-based study by Hoxby and Rockoff (2004) looks at a large system of charter schools in Chicago. They find that enrolling in charter schools by grade five raises achievement levels by about six percentiles. Another study by Hoxby (2004) compares charter students in the United States to their fellow students in neighboring public schools and finds that overall charter students are 3.2 percent more likely to be proficient in mathematics and 5.2 percent more likely to be proficient in reading. When looking at individual states, Hoxby (2004) finds that in Arizona, fourth grade charter students are about 10 percent more likely to be proficient in reading and math than students in the matched traditional public schools. Hoxby (2004) also finds that in California, the proficiency advantages are 9 percent in reading and 5 percent in math, and in Colorado, the proficiency advantages are 12 percent in reading and 14 percent in math. North Carolina was the only state in which charter students' proficiency is statistically significantly lower, by 4 percent, in both reading and math, compared to students in the nearest public school. In addition, Texas' charter students appear to be statistically significantly less proficient in math (not reading). (Hoxby 2004)

Although the amount of evidence indicating the positive benefits from charter schools has recently been growing, the literature has neglected to analyze whether the effect differs between for-profit and nonprofit charter schools. In this paper I explore whether the for-profit motive in education produces even greater benefits in Arizona's for-profit charter schools than in the nonprofit charter schools with which they compete. ${ }^{65}$

\footnotetext{
${ }^{65}$ It should be noted that both for-profit and nonprofit charter schools in Arizona generally locate in larger cities so that any endogeneity in the choice of location is not an issue for the comparison used in this study.
} 
Although there are many states that have both for-profit and nonprofit charter schools in operation, at the time this paper was written, Arizona was the only state for which a sufficient amount of for-profit student achievement data was available for a concrete analysis. $^{66}$ My results indicate that average student test scores at various elementary grade levels in the for-profit charter schools were between 1.65 and 6.15 percentile points higher in the 2002-03 school year and between 2.65 and 6.47 percentile points higher during the 2003-04 school year when compared to nonprofit charter schools in the same state.

The set up of this chapter is as follows. Section 4.2 defines how charter schools operate and discusses the current empirical findings related to competition and student achievement. Section 4.3 presents the theoretical model for measuring student outcomes from which the empirical model is developed. Section 4.4 describes the data used in this analysis. Section 4.5 presents the empirical model and Section 4.6 describes the results. Section 4.7 presents concluding remarks and implications of this analysis.

\subsection{Charter Schools and Competition}

Charter schools are defined by the U.S. Department of Education as independent public schools designed and operated by educators, parents, community leaders, and other educational entrepreneurs. Each charter school has a governing board and a sponsoring entity which monitors the quality and effectiveness of the school. Charter schools can be organized as either nonprofit corporations or as for-profit corporations and must comply

\footnotetext{
${ }^{66}$ The charter school laws of at least 12 states (AZ, CA, CO, CT, IL, KS, LA, MA, MI, MN, NJ, and NC) allow for-profit companies to operate publicly funded charter schools. In several of these states, charters have become the point of entry for school management companies. AZ, MA, and MI are the leaders in forprofit charter school management. [Online] Available at URL Source: www.corpwatch.com.
} 
with everything in its charter contract with the state as well as all applicable federal and local laws and regulations. These schools also develop their own policies related to discipline, personnel, attendance, and curriculum which can help to remove the inefficiencies often created by the bureaucracy inherent in traditional public schools.

The goals of many typical charter schools can be summarized as follows: (1) continue to improve student learning, (2) encourage the use of different and innovative teaching models, (3) create new professional opportunities for educators to design and implement learning programs, (4) increase choice of learning opportunities for students, (5) establish new models of public schools and a new form of accountability, and (6) provide for greater parent involvement. ${ }^{67}$

Charter schools like traditional public schools are state-funded, however, charter schools receive fees on a per student basis. Although all charter schools must implement open enrollment, some target toward specific student populations such as teen mothers, students with disabilities, students interested in the arts, or students who do not perform well in a formal school setting.

There are approximately 3,400 charter schools operating in the United States, an estimated 50 percent increase since the year 2000. In Arizona there are currently 491 charter schools in operation serving 73,542 students. ${ }^{68}$ Arizona passed its charter school law in 1994 and charter schools began operating during the 1995-96 school year. Table 4.1 displays the progression of charter schools in Arizona over the past 9 years. The data shows that charter school enrollment saw a 42 percent increase from the 1997-98 to

\footnotetext{
${ }^{67}$ These goals were taken from the following website: http://www.usoe.k12.ut.us/charterschools/legislation.htm.

${ }^{68}$ Arizona has the second largest number of charter schools and students in the United States. California has the largest with 500 charter schools in operation serving 153,195 students.

Source: The Center for Education Reform, 2005. [Online] Available at URL http://www.edreform.com.
} 
1998-99 school year and a 14 percent increase from the 2001-02 to 2002-03 school year.

A small decrease is seen from 2002-03 to 2003-04 which is most likely due to the consequence of having a cap on the number of charter schools chartered each year.

Table 4.1 Charter Schools and Enrollment for Arizona (1995-2004)

\begin{tabular}{|c|c|c|c|c|c|c|c|c|c|}
\hline & $\begin{array}{l}1995- \\
96\end{array}$ & $\begin{array}{l}1996- \\
97\end{array}$ & $\begin{array}{l}1997- \\
98\end{array}$ & $\begin{array}{l}1998- \\
99\end{array}$ & $\begin{array}{l}1999- \\
00\end{array}$ & $\begin{array}{l}2000- \\
01\end{array}$ & $\begin{array}{l}2001- \\
02\end{array}$ & $\begin{array}{l}2002- \\
03\end{array}$ & $\begin{array}{l}2003- \\
04\end{array}$ \\
\hline Schools & 51 & 133 & 163 & 252 & 322 & 339 & 391 & 446 & 491 \\
\hline Students & 7,350 & 16,650 & 25,500 & 36,250 & 46,350 & 55,586 & 65,769 & 75,135 & 73,542 \\
\hline
\end{tabular}

Sources: Glass, 2004, 1995-96 to 1999-2000 (Nunez, D.R., 2001). Counting Students in Arizona Charter Schools. Dissertation, Arizona State University); 2000-01 to 2002-03 (Arizona Department of Education, Research and Policy Section); 2003-04 (The Center for Education Reform).

\subsection{The For-Profit and Nonprofit Models}

The educational production function has been used extensively in the literature to look at both the level of and growth in student achievement. In addition, value-added measures have arguably become the most common way to deal with the limitations of the education production function when analyzing school quality. ${ }^{69}$ A school's value added can be defined as the amount of student learning during the year that is attributable to the school. The value-added approach focuses on the gains in student achievement rather than simply the levels of student performance. The advantage of this approach is that it eliminates potential bias that may result from prior unobservable family and school inputs. In this paper, I use the educational production function while implementing the value-added

\footnotetext{
${ }^{69}$ For a few examples see Hanushek and Kain (2005), Meyer (1997), and Summers and Wolfe (1997).
} 
approach by using the previous year's test score as a control variable to compare student achievement levels in for-profit and nonprofit charter schools. In particular I analyze the characteristics of for-profit and nonprofit charter schools and the incentives faced by their administrators. The production function is as follows,

$$
Y_{t}=f\left(Y_{t-1}, X, N S, e\right)
$$

where $Y_{t}$ measures student performance based on standardized test scores in year $t ; Y_{t-1}$ represents lagged test scores; $\mathrm{X}$ represents school inputs such as teachers, school administration, transportation and facilities; NS represents non-school factors such as student motivation and innate ability, family characteristics, neighborhood characteristics and peer effects; e represents the random error; and $f(\cdot)$ represents the production process.

By analyzing student achievement levels in both for-profit and nonprofit charter schools, this paper tests whether the incentives of administrators in a for-profit charter school have a positive impact on charter school quality. Because charter schools are financed primarily by the state based on enrollment, the incentives of the school administrators are first to keep enrollment high, and second to continue to attract new students. This assertion is the principal idea behind why school choice creates competition for students. Because administrators want larger budgets and because budgets increase with enrollment, schools engage in active competition for students. In order to maximize student enrollment, charter school administrators must attract parents away from traditional public schools. Hoxby (1999) suggests that parents prefer schools with better academic achievement records, although other characteristics may influence 
this decision as well. For the purposes of this paper, it is assumed that parents enroll their child in the school with the best achievement levels as signified by high test scores.

The most important difference between for-profit and nonprofit charter schools is contained in the question of what it is that the producers of education maximize. I use a model developed by Hoxby (2003), which compares the incentives faced by for-profit and nonprofit charter schools. When examining the for-profit model, it is assumed that the charter school could charge a fee that was set by law and could not be topped up by parents. In addition, the school is also required to accept students by a random process such as a lottery. The school would solve a maximization problem as follows,

$$
\operatorname{Max}_{\mathrm{q}, \mathrm{s}, \mathrm{z}} \pi=\mathrm{fx}(\mathrm{q})-\mathrm{c}(\mathrm{q}, \mathrm{s}, \mathrm{w}, \mathrm{z}, \mathrm{p}) \mathrm{x}(\mathrm{q}) .
$$

The idea is that a school maximizes the difference between revenues and costs. Its revenues are composed of the fixed fee, $f$, times student enrollment, $x$. The school's costs, $c$, are the per-pupil cost times the number of students enrolled. The school chooses the quality $q$ to offer based on the labor it hires, $s$, and the other inputs it employs, $z$. The wage rate for staff is $w$, and the price for inputs is $p$. The per-pupil costs are increasing in quality, staff hired, and other inputs, but they are independent of enrollment.

Since parents choose the school that offers the highest school quality in terms of performance levels, enrollment is increasing in quality. Schools must compete for students by means of quality of education, and the schools that offer the highest quality will enroll all of the public school students in that area up to their capacity. Lower quality schools will be driven out of the market. Therefore enrollment is given by, 


$$
\mathrm{x}\left(\mathrm{q}_{\mathrm{j}^{*}}\right)=\sum_{j=1}^{N} 1 \text { if } \mathrm{q}_{\mathrm{j}^{*}}>\mathrm{q}_{\mathrm{j} \neq \mathrm{j}^{*}} \text { for all } \mathrm{j}
$$

$$
x\left(q_{j^{*}}\right)=0 \text { if } q_{j^{*}}<q_{j \neq j^{*}} \text { for any } j .{ }^{70}
$$

Therefore, a school must maximize its performance level otherwise a higher quality school will attract away its' students. The school earns just enough profit to pay its shareholders a market rate of return for the use of their capital, so the goal is to maximize the number of students on which it earns a small profit. As Hoxby (2003) shows, if economies of scale exist, managers of for-profit firms may be able to earn economic profits in local markets where they compete with other schools by pooling together in buying inputs, curricular research and development, and information processing.

Glaeser and Shleifer (2001) find that another key difference between for-profit and nonprofit organizations is the distribution of surplus. A nonprofit school cannot directly distribute surplus to any one particular group or person. The surplus can be distributed in ways that create a better work environment such as more supplies, catered meetings, new computers, and so on. These types of distributions are almost always wasteful in the sense that distributing cash (as for-profit schools do) rather than goods and services creates a much higher incentive structure for staff members. The distribution of goods and services are rarely concentrated to one single person or a specific group of staff members, therefore the school decision makers face weaker incentives to expand enrollment in order to increase the surplus and hence faces weaker

\footnotetext{
${ }^{70}$ See Hoxby (2003) for further details.
} 
incentives to keep the school at a high performing level. The nonprofit charter school's maximization problem incorporates the distribution of surplus and is as follows,

$$
\operatorname{Max}_{\mathrm{q}, \mathrm{s}, \mathrm{z}}(\varphi \cdot \pi) / \mathrm{s}=\varphi \cdot[\mathrm{fx}(\mathrm{q})-\mathrm{c}(\mathrm{q}, \mathrm{s}, \mathrm{w}, \mathrm{z}, \mathrm{p}) \mathrm{x}(\mathrm{q})] / \mathrm{s}
$$

where enrollment is given by,

$$
\begin{aligned}
& \mathrm{x}\left(\mathrm{q}_{\mathrm{j}^{*}}\right)=\sum_{j=1}^{N} 1 \text { if } \mathrm{q}_{\mathrm{j}^{*}}>\mathrm{q}_{\mathrm{j} \neq \mathrm{j}^{*}} \text { for all } \mathrm{j}, \\
& \mathrm{x}\left(\mathrm{q}_{\mathrm{j}^{*}}\right)=0 \text { if } \mathrm{q}_{\mathrm{j}^{*}}<\mathrm{q}_{\mathrm{j} \neq \mathrm{j}^{*}} \text { for any } \mathrm{j} .
\end{aligned}
$$

The maximization problem suggests that a staff member wants the school to maximize the surplus $\pi$ which is multiplied by $\varphi$ and then divided by the number of staff members, s. $\varphi$ is a factor less than one which gives the share of surplus that remains after it has been transformed into goods for the staff. As before, the revenues are composed of the fixed fee, $f$, times student enrollment, $x$ and the school's costs, $c$, are the per-pupil cost times the number of students enrolled. The school chooses the quality $q$ to offer based on the labor it hires, $s$, and the other inputs it employs, $z$. The wage rate for staff is $w$, and the price for inputs is $p$. This maximization problem implies that nonprofit schools face weaker incentives than for-profit schools to expand enrollment implying that a positive correlation between for-profit charter schools and student achievement could exist.

\subsection{Data}

I use scores from two standardized tests to measure student performance in Arizona's charter schools, both of which were collected from the Arizona Department of Education.

\footnotetext{
${ }^{71}$ See Hoxby (2003) for further details.
} 
The first measure of student performance in Arizona's charter schools comes from a nationally standardized norm-referenced achievement testing program in the subjects of reading, language, and mathematics given to students in grades two through nine. This test, known as the Stanford 9, uses the percentile rank to compare each student's performance on the test to the performance of a representative sample of public school students of the same age and grade. The percentile rank, reported in units that range from 1 through 99 , is the most common and readily understood score for interpreting student achievement. This ranking describes performance in small precise units relative to a norm group. For example, a percentile rank score of 68 means that the student earned a raw score that was higher than 68 percent of the students in the norm group who were in the same grade and took the same test.

The second measure of student performance is a standards-based test called Arizona's Instrument to Measure Standards (AIMS) which provides information regarding the progress of students toward mastering Arizona's reading, mathematics and writing standards. The AIMS test is given to students in grades three, five, eight, ten, eleven, and twelve and is similar to the Stanford 9 in that it uses percentile ranking, however, AIMS scores are grouped into four performance standard categories as well: falls far below the standard, approaches the standard, meets the standard, and exceeds the standard. $^{72}$ This study uses data from both the 2002-03 and the 2003-04 school years and concentrates on grades three and five.

\footnotetext{
${ }^{72}$ Unlike traditional scores where student achievement is presented only in terms of numeric scores, performance standards are descriptors that provide concrete and meaningful information about student performance. These standards were created by a committee of experienced educators, experts in the fields of reading, writing and mathematics. Source: Arizona Department of Education, [Online] Available at URL http://www.ade.state.az.us/.
} 
In determining the control variables, I rely heavily on those variables proposed in the literature. A substantial amount of research has been conducted on the effects of teacher characteristics on student learning such as teachers' educational background, years of experience, and salaries. Although Hanushek (1986) has found that teaching experience and graduate education do not contribute to student achievement, these factors are still commonly used in the literature as inputs in the education production function. ${ }^{73}$ Other commonly used variables included to capture demographic characteristics of students are minority status and per capita income. The teacher characteristics, minority status, and legal entity of the charter school were collected individually from each school's annual report card available from the Arizona Department of Education. Per capita income, a proxy for family background, was collected from the Bureau of Economic Analysis. $^{74}$

\subsection{Empirical Model}

In both the for-profit and nonprofit charter models, school administrators seek to maximize the school's profits and do so by increasing student enrollment. According to the theoretical model, for-profit charter school administrators face greater incentives to attract new high quality students when compared to the nonprofit administrators. This implies that staff members will be more motivated to implement new innovations for learning, and will also be more likely to create an environment of high school quality that

\footnotetext{
${ }^{73}$ For a few examples see Hanushek and Kain (2005), Darling-Hammond (2000), Krueger (1999), Summers and Wolfe (1977).

${ }^{74}$ Per capita income in 2001 was used for school year 2001-02 and per capita income in 2002 was used for school years 2002-04.
} 
attracts parents and thus students. This idea can be tested empirically by using a standard education production function as follows,

$$
\text { Score }_{t}=\alpha+\beta \text { Score }_{t-1}+\delta \text { Inputs }_{t}+\theta \text { ForProfit }+\lambda \text { Income }_{t}+\mu \text { PercentMinority }+\mathrm{e}_{\mathrm{t}}
$$

where Score $_{t}$ equals the achievement level obtained by a particular school in year $t$, Score $_{t-1}$ is that school's achievement level in the prior year, Inputs $t_{t}$ is a vector of measurable school inputs, which includes teacher education levels and years of experience in each charter school in year $\mathrm{t}^{75}$ ForProfit represents the legal entity of the charter school and is included as a dummy variable equaling one if the school is for-profit and zero otherwise. Income equals the income per capita for the county in which the charter school is located and is used as a proxy for current family characteristics and PercentMinority represents the percentage of minority students in each charter school in year t. Left out of the equation are the unmeasured student characteristics such as innate ability and motivation.

Because the focus of this paper is to test whether being a for-profit charter school has an impact on student achievement levels, the most important aspect of the above model is the ForProfit parameter estimate. The results of the regression analysis, which involves testing the null hypothesis $\mathrm{H}_{0}: \theta=0$ against the alternative hypothesis $\mathrm{H}_{1}: \theta \neq 0$, is expected to reveal that the for-profit motive improves student achievement levels.

\footnotetext{
${ }^{75}$ In addition to the above equation, the change in scores, that is, Score $_{t}-$ Score $_{t-1}$ was also used as a dependent variable for both exams. The results are very similar to those found from using equation 4.8 and thus are not reported.
} 


\subsection{Estimation Results}

The education production function was estimated using least squares regression analysis and a value-added approach. ${ }^{76}$ Table 4.2 highlights the results reporting the ForProfit estimates using data from the Stanford 9 proficiency exam in the 2002-03 and 2003-04

Table 4.2 Estimated Determinants of Student Achievement Using a For-Profit and Nonprofit Comparison, Dependent Variable: Average Test Score on the Stanford 9 Exam

\begin{tabular}{l|ll}
\hline & $2002-03$ & $2003-04$ \\
\hline $2^{\text {nd }}$ Grade & 0.13 & 1.84 \\
ForProfit & $(0.07)$ & $(0.89)$ \\
& $4.08^{* *}$ & $6.47^{* *}$ \\
$3^{\text {rd }}$ Grade & $(2.58)$ & $(3.66)$ \\
ForProfit & & \\
& -1.09 & $2.65^{*}$ \\
$4^{\text {th }}$ Grade & $(0.69)$ & $(1.77)$ \\
ForProfit & $2.55^{*}$ & 2.08 \\
& $(1.67)$ & $(1.32)$ \\
$5^{\text {th }}$ Grade & $1.65^{* *}$ & $3.15^{* *}$ \\
ForProfit & $(1.95)$ & $(3.53)$ \\
Pooled Grades & & \\
ForProfit & & \\
\hline
\end{tabular}

Notes. t-statistics are in parentheses and the asterisks indicate significance as follows: $* * *=1 \%, * *=5 \%$, $*=10 \%$.

${ }^{76}$ In addition to running ordinary least squares, a basic model of spatial correlation developed by Cliff and Ord (1981) and Anselin (1988) was used to test for either spatial dependence in the dependent variable, or spatial dependence in the error component. The estimated spatial autoregressive coefficient and the spatial error correlation coefficient were neither significantly different than zero implying that the model does not have a spatial dependence problem. 
school years for grades two, three, four, and five. ${ }^{77}$ The three subjects tested, reading, mathematics, and language, were pooled for each grade level in order to gain a sufficient amount of for-profit observations. For the 2002-03 school year, the coefficient of interest, ForProfit, was found to be positive and significant for grades three and five, and insignificant for grades two and four. In addition, when all of the grade levels were pooled, ForProfit was found to be positive and significant at the five percent level. The results from the pooled regression indicate that students in the for-profit charter schools on average scored 1.65 percentile points higher than the nonprofit charter schools with which they were compared. A similar finding is found for the 2003-04 school year with the coefficient of ForProfit being positive in all grades and significant for grades three and four. When the grades are pooled in the 2003-04 school year the coefficient for ForProfit is again found to be positive and significant indicating that students in the forprofit charter schools on average scored 3.15 percentile points higher than their nonprofit counterparts.

Tables 4.3 and 4.4 highlight the results reporting the ForProfit estimates using data from the Arizona Instrument to Measure Standards (AIMS) exam. The three subjects tested, mathematics, reading, and writing are pooled for the school years 2002-03 and 2003-04. ${ }^{78}$

In Table 4.3, students in grade three are ranked according to those who meet or exceed

\footnotetext{
${ }^{77}$ Tables A.2 and A.3 in the Appendix report the results of all coefficient estimates using the Stanford 9 exam. Note that PercentMinority is positive and significant in all equations contrary to previous research. This positive sign is most likely due to the large number of Native Americans in Arizona which are included as minority students in this analysis. The coefficients included to account for teacher characteristics vary extensively in sign and significance which is consistent with previous research. Income per capita is found to be insignificant in all but one equation.

${ }^{78}$ Tables A.4 and A.5 in the Appendix report the results of all coefficient estimates using the AIMS exam. Note here that PercentMinority is negative and significant in most equations while the variables used to represent teacher characteristics are mostly insignificant. Income per capita is again insignificant in most cases.
} 
the standard set by the state of Arizona. The results indicate that in the 2002-03 school year, students in the for-profit charter schools who exceeded the standard were on average scoring 4.91 percentile points higher than students in the nonprofit charter schools. In addition, when grouping meet and exceed the standard together, students in the for-profit charter schools who met and exceeded the standard were on average scoring 3.15 percentile points higher than students in the nonprofit charter schools.

Similar results are reported in Table 4.4 for students in the fifth grade. The results indicate that in the 2002-03 school year, students in the for-profit charter schools who met the standard were on average scoring 6.15 percentile points higher than students in the nonprofit charter schools. In addition, when grouping meet and exceed the standard together, students in the for-profit charter schools who met and exceeded the standard were on average scoring 5.53 percentile points higher than students in the nonprofit charter schools.

Table 4.3 Estimated Determinants of Student Achievement Using a ForProfit and Nonprofit Comparison, Dependent Variable: Average $3^{\text {rd }}$ Grade Test Score on Arizona's Instrument to Measure Standards Exam

\begin{tabular}{l|ll}
\hline $3^{\text {rd }}$ Grade & $2002-03$ & $2003-04$ \\
\hline MEET STANDARD & -1.76 & -0.62 \\
ForProfit & $(0.82)$ & $(0.29)$ \\
& & \\
EXCEED STANDARD & $4.91 * *$ & 1.41 \\
ForProfit & $(2.63)$ & $(0.72)$ \\
MEET+EXCEED STANDARD & & \\
ForProfit & $3.15^{*}$ & 1.01 \\
& $(1.73)$ & $(0.43)$ \\
\hline
\end{tabular}

Notes. t-statistics are in parentheses and the asterisks indicate significance as follows: $* * *=1 \%, * *=5 \%$, $*=10 \%$. 
Table 4.4 Estimated Determinants of Student Achievement Using a For-Profit and Nonprofit Comparison, Dependent Variable: Average $5^{\text {th }}$ Grade Test Score on Arizona's Instrument to Measure Standards Exam

\begin{tabular}{l|lc}
\hline $5^{\text {th }}$ Grade & $2002-03$ & $2003-04$ \\
\hline MEET STANDARD & $6.15^{* *}$ & -3.75 \\
ForProfit & $(2.60)$ & $(1.62)$ \\
& & \\
EXCEED STANDARD & 1.82 & -0.88 \\
ForProfit & $(0.77)$ & $(0.59)$ \\
MEET+EXCEED STANDARD & & \\
ForProfit & $5.53 * *$ & -3.10 \\
& $(2.13)$ & $(1.37)$ \\
\hline
\end{tabular}

Notes. t-statistics are in parentheses and the asterisks indicate significance as follows: $* * *=1 \%, * *=5 \%$, $*=10 \%$.

\subsection{Conclusion}

The idea behind implementing school choice is to use market forces to direct labor and capital to their most productive functions. Without the benefit of the profit motive, however, nonprofit charter schools fail to fully address the inefficiencies of public education. The model developed by Hoxby (2003), discussed earlier in this paper, showed that for-profit charter schools face greater incentives to expand student enrollment when compared to nonprofit charter schools. In order to expand enrollment, for-profit charter schools must be able to attract parents by keeping their current student test scores at a high level. Therefore, Hoxby's model predicts that for-profit charter schools will see higher student achievement levels when compared to their nonprofit counterparts. According to my results, for-profit charter schools are achieving higher test scores confirming what Hoxby predicted. My findings clearly indicate that nonprofit charter schools exhibit less motivation to expand or improve their services when compared to for-profit charter schools. 
Research has shown that the public education sector has performed very poorly when compared to economic sectors in which the profit motive is present such as the health care and information technology fields. Until recently, the general absence of the profit motive has discouraged possible entrepreneurs from investing financial resources into schooling. School choice has now allowed for-profit entities to enter the education sector, encouraging the competition this market has been lacking. Based on the results from the Stanford 9 and AIMS exams, the impacts of the profit motive on student achievement levels in charter schools are indeed positive.

As school choice continues to be analyzed for its impacts on student achievement, it is important to determine what type of environment would allow competition to most effectively operate. This paper is the first to confirm that the structure of a for-profit charter school can work to improve student outcomes above what nonprofit charter schools have been able to achieve. 


\section{Chapter 5}

\section{The Effects of Vouchers on Student Achievement in Urban and Rural Districts: Evidence from Cleveland, Ohio}

\subsection{Introduction}

The overlapping goal of all types of school choice is to provide parents the opportunity to choose a school which offers a high quality education and produces competitive student outcomes. When it comes to education reform, proponents of school choice claim that a free market in education would work to raise productivity in the public school sector. This argument rests on two claims. First, it is often argued that private schools are more efficient than public schools. School choice could therefore improve student outcomes by facilitating the transfer of students to the private sector. The second argument for school choice says that without competition, public schools face weak incentives to improve. Educational vouchers are a form of school choice that are defined as, "government grants aimed at improving education for the children of low-income families by providing school tuition that can be used at public or private schools." ${ }^{, 79}$ It has been hypothesized by many economists that school vouchers would create an education market where competition from private schools would create incentives for public schools to be more innovative and provide a better education for their students as well as help to raise public school productivity. ${ }^{80}$ The first piece of evidence suggesting that public schools react to outside competition is demonstrated by Hoxby (1994) who finds that public schools in areas that have larger concentrations of private Catholic schools perform better than those facing less private competition. More recently, Hanushek and

\footnotetext{
${ }^{79}$ Education voucher, 2005. [Online] Available at URL http://www.answers.com.

${ }^{80}$ Milton Friedman is most referenced economist on this issue.
} 
Rivkin (2003) have found that more competition tends to increase teacher quality. This result is of great importance given that teacher quality is one of the primary determinants of school quality.

Opponents of vouchers believe that school choice programs drain resources from public schools that are already in dire need of new buildings, more textbooks, higher teacher salaries, and so on. Proponents contend that it is the school bureaucracies who are at fault for diverting resources from real educational activities and say that school choice would only work to redirect funding to where it belongs. Opponents also contend that those who will take advantage of the voucher's and other school choice options will be the more advantaged students leaving the disadvantaged students worse off in the long-run. This idea of "cream-skimming" has been widely studied in the educational literature. Howell and Peterson (2002) summarize evidence from three privately funded voucher programs in New York City, Dayton, Ohio and Washington D.C comparing families who accept and those who decline vouchers. In terms of the socio-demographic characteristics, the authors found that applicant families were more likely to be two parent households, have a slightly higher percentage of mothers who are college graduates, move less frequently, were more likely to be African American and less likely to be Hispanic, and were more likely to attend church at least once a week. There was also evidence that applicant families were more likely to be involved in schools using data on attendance at parent teacher conferences and volunteering in the school. In terms of academic differences, the authors found that students who used a voucher to attend the lower elementary grades had slightly higher reading scores than those who did not use the voucher. Overall, the authors found that the Dayton program sees modest, statistically 
significant negative selection on math scores, the New York City and Washington D.C. programs see small, statistically insignificant positive selection in math scores for grades one through five, and finally for the D.C. program for grades six through eight, a statistically significant positive difference of 6.3 percentile points was found. Howell and Peterson (2002) summarized their evidence on selection associated with school vouchers targeted to low-income populations by saying, "On the whole, these findings earn school vouchers a surprisingly positive grade on the selection line of the report card." Howell and Peterson (2002) also studied the Cleveland voucher program and found no clear pattern of positive selection.

In terms of other school choice options, Bulkley and Fisler (2002) briefly reviewed the evidence on the racial and socioeconomic composition of charter schools. The authors showed that the RPP International 2001 study found that the racial and ethnic composition of charter schools is similar to that of the school district. Additionally, they found little indication that charter schools lead to a large exodus of the most advantaged children from regular public schools.

Although there are many studies that find parental satisfaction in terms of vouchers and charter schools, policymakers are most often focused only on test scores as a gauge for whether or not school choice is effective ${ }^{81}$ Studies conducted to measure the effects of school choice on educational outcomes typically offer positive results. Cullen et. al (2004) look at the Chicago Public School system and the effects of open enrollment and find no specific benefits using academic measures such as standardized test scores

\footnotetext{
${ }^{81}$ Peterson, Paul E., William G. Howell, and Jay P. Greene, 1998. "An Evaluation of the Cleveland Voucher Program After Two Years," Harvard Program on Education Policy and Governance Working Paper.
} 
and attendance rates. The authors do however find some evidence of improved outcome measures through lower disciplinary incidences and arrest rates. Hoxby (2001) measures the effects of school choice on school productivity and finds gains in productivity when analyzing vouchers in Milwaukee, and charter schools in both Michigan and Arizona. Greene (2001) analyzes the effects of Florida's voucher program and finds that after the first year, schools that were receiving a failing grade according to the state's grading system and hence subject to the voucher system, raised achievement significantly more than comparable schools not subject to the threat of vouchers.

Many authors who analyze the effects of school choice on student outcomes focus on a particular subset of students who participate in some form of school choice and compare them to students who choose to stay at their assigned public school. For example, Rouse (1998) studied the effects of vouchers through the Milwaukee Parental Choice Program and found that students in the program had faster math score gains but similar reading score gains when compared to students not in the program. Wolf et. al (2001) studied a privately funded voucher program in Washington D.C. and found that African American students who switched to private schools scored 9 national percentile rank points higher than their public school peers in combined math and reading achievement. After studying the Cleveland Scholarship and Tutoring Program, Metcalf (1999) reported that "scholarship students in existing private schools had significantly higher test scores than public school students in language (45.0 versus 40.0$)$ and science (40.0 versus 36.0 ). However, there were no statistically significant differences between these groups on any of the other scores." 
The focus of this chapter is to analyze the effects of vouchers in terms of the competition that this type of school choice is predicted to create. Therefore, instead of analyzing the test scores of the students participating in the program, I examine the effects of school choice on the individual public schools in the region from which the students are leaving. Given that voucher programs have typically been implemented to help the plight of low performing urban schools, it is important to compare urban school district and rural school district student outcomes to see what differences or similarities arise between the two regions. More specifically, I analyze how the introduction of vouchers in the Greater Cleveland Area has impacted both urban and rural public school performance on proficiency tests in the subjects of citizenship, mathematics, reading, science, and writing. My results indicate that the voucher program is having a positive effect on average test scores for the students who stay in the public schools for both the urban and rural areas in the Cleveland region with the urban schools seeing greater improvements in terms of the magnitude of the test scores.

This chapter of the dissertation is set up as follows. Section 5.2 presents the theoretical model for measuring student outcomes from which the empirical model is developed. Section 5.3 describes the data and Section 5.4 estimates the model for the 2002-03 and 2003-04 school years. Section 5.5 presents concluding thoughts and implications of this analysis.

\subsection{Theoretical Model}

Cleveland, Ohio presents a unique opportunity for conducting research on the effects of school choice on student outcomes. In particular, Cleveland enacted a publicly funded 
school voucher program in 1995 which today is one of only six such programs in the United States to use a fully funded system. ${ }^{82}$ The Cleveland program has grown from 1,994 students in 1996-97 to 5,098 students attending over 50 religious and nonreligious private schools in 2003-04. ${ }^{83}$ Vouchers, or scholarships as they are sometimes called, are awarded by lottery and preference is given to families whose incomes fall below 200 percent of the federal poverty level, which was $\$ 37,770$ for a family of four in 2004 .

In order to analyze the effects of vouchers on student outcomes it is important to understand the theory behind measuring educational attainment. A widely accepted approach to estimating educational outcomes is by measuring the effects of various levels and combinations of educational inputs on student outcomes through the use of the education production function. The education production function determines the amount of output that results from a certain level of inputs. Typically the output of education is measured through achievement on standardized test scores or through the job market, measured by earnings. Extensive research has been done using a variety of educational inputs. Some of the most common inputs to education include teacher characteristics such as highest degree earned, years of experience and teacher salaries. Another category of inputs include school characteristics such as expenditures per pupil, class size and student teacher ratio. The final group of widely recognized school inputs can be referred to as socio-demographic characteristics which include specific student attributes such as innate ability, neighborhood effects, peer effects, and parent's education and income. The outcomes that have been reported from using these various input measures in the education production function have given rise to much controversy.

\footnotetext{
${ }^{82}$ The other fully funded voucher programs are found in Milwaukee, Wisconsin and in cities throughout the state of Florida, Maine, and Vermont.

${ }^{83}$ Ohio Department of Education's Office of Cleveland Scholarship and Tutoring Program.
} 
One of the earliest investigations of the link between school inputs and student outcomes was done by Coleman (1966) who found very little evidence of school resources having an impact on academic achievement. Hanushek (1996) summarized more than 300 studies that measured a variety of the above mentioned inputs and found that in general the results indicate that there is no strong systematic relationship between school expenditures and student performance. Studies by Card and Krueger (1996) did find a positive relationship between expenditures per pupil and the student teacher ratio in earnings across a wide range of age groups. Taylor (1999) and Pogue et al. (1999) control for family backgrounds and also find positive effects of additional resources as measured by student performance.

Even with mixed results the education function production continues to be the most preferred method of analyzing the relationship between inputs to education and the resulting outcomes. Todd and Wolpin (2003) summarize a variety of modeling approaches used in the education production function literature. As they point out, early studies such as Hanushek (1986) only used contemporaneous inputs while more recent studies use a value-added approach to alleviate the need for data on historical inputs and endowments.

In order to test for the effects of vouchers on public school performance, I will adopt the value-added approach. This estimation technique has been used in the literature due to data limitations on input histories and in its most common form, relates an achievement outcome measure to school and family inputs and a lagged achievement measure. The following specification can be used to represent the education production function, 


$$
A_{i j t}=f\left(A_{i j t-1}, T_{i j t}, S_{j t}, X_{j t}\right)
$$

where $\mathrm{A}_{\mathrm{ijt}}$ is output and represents student achievement of each individual school, $i$, in a particular district $j$ at time $t$. The inputs are represented by a vector of teacher characteristics $\mathrm{T}_{\mathrm{ij}}$, a vector of school inputs, $\mathrm{S}_{\mathrm{jt}}$, and a vector of student attributes, neighborhood effects, and peer effects, $X_{j \mathrm{j}} . \mathrm{A}_{\mathrm{ijt}-1}$ represents the lagged achievement measure which in this case will be based on standardized test scores.

\subsection{Data}

The test score data for this study comes from the Ohio Department of Education and is based on a proficiency exam administered to students in the fourth grade for the 2003-04 and 2002-03 school years. The results of the exam are reported as the percentage of students who meet or exceed a proficiency level set by the state of Ohio. Students are tested in citizenship, mathematics, reading, writing, and science. This chapter's focus is to analyze the effects of vouchers on public school performance, so I have chosen the Greater Cleveland Area for the study due to the fact that fully funded vouchers are currently only available in this region. The Greater Cleveland Area is broken up into 12 school systems or smaller districts with each school system containing a certain number of individual schools. Table 5.1 lists the 12 school districts, and the number of individual schools within each school system. 


\section{Table 5.1 The 12 School Systems in the Greater Cleveland Area and the Associated Number of Schools}

\begin{tabular}{|l|c|}
\hline Greater Cleveland School Districts & Number of Schools \\
\hline Beachwood School System & 5 \\
\hline $\begin{array}{l}\text { Cleveland Heights-University Heights } \\
\text { School System }\end{array}$ & 13 \\
\hline Cleveland Public Schools & 91 \\
\hline Diocese of Cleveland Office of Catholic Education & 3 \\
\hline Independence Local Schools & 14 \\
\hline Lakewood Schools & 16 \\
\hline Mentor Exempted Village School District & 9 \\
\hline North Olmsted City Schools & 4 \\
\hline Olmsted Falls City Schools & 3 \\
\hline Orange City Schools & 7 \\
\hline Shaker Heights City School District & 14 \\
\hline Willoughby-Eastlake City Schools & \\
\hline
\end{tabular}

Source: Ohio Department of Education.

For the empirical analysis, each of the 12 school systems are matched with other school systems or districts throughout the state based on a variety of characteristics such as average daily membership, percent of the population with administrative or professional occupations, median income, percent of the population with a college degree, population density, percent of non-residential and non-agricultural land per pupil 
and percent minority students. Tables A.7-A.10 in the Appendix display the matched districts and the data used in deriving comparable systems. ${ }^{84}$

Data used for teacher characteristics also comes from the Ohio Department of Education which has developed categories such as the percent of teachers who are highly qualified, the percent of teacher's who are fully certified, along with the normally reported categories such percent of teachers with a Master's degree and years of experience.

\subsection{Empirical Model and Estimation Results}

For empirical purposes I follow the current literature and assume that the education production function is linear to generate a general regression equation,

$$
\mathrm{A}_{\mathrm{ijt}}=\alpha+\varphi \mathrm{A}_{\mathrm{ijt}-1}+\gamma \mathrm{T}_{\mathrm{ijt}}+\rho \mathrm{S}_{\mathrm{jt}}+\lambda \mathrm{X}_{\mathrm{jt}}+\varepsilon_{\mathrm{ijt}}
$$

where $A_{i j t}$ represents achievement on the Ohio proficiency test measured by the percentage of students at or above the proficient level at school $i$, in district $j$, at time $t$, with $\mathrm{A}_{\mathrm{ijt}-1}$ representing the lagged test score. The vector of inputs measuring teacher characteristics in this study is based on a variety of teacher attributes such as years of experience and level of education which is used by the Ohio Department of Education to develop a measure for the percentage of teachers considered to be highly qualified to teach in each individual school. The vector of school inputs, $\mathrm{S}_{\mathrm{jt}}$, and the vector of student attributes, neighborhood effects, and peer effects, $\mathrm{X}_{\mathrm{jt}}$ used in the model are based on the

\footnotetext{
${ }^{84}$ Only 4 districts contain enough data for an analysis, this point is made later in the paper as well.
} 
categories used to match similar districts. Therefore, the specific regression equation I use to test for the effects of vouchers on public school student achievement is as follows,

$$
\begin{aligned}
\text { Score }_{\mathrm{ijt}}= & \alpha+\varphi \text { Score }_{\mathrm{ijt}-1}+\sigma \text { Voucher }_{\mathrm{ijt}}+\operatorname{\theta Minority}_{\mathrm{jt}}+\delta \text { Enrollment }_{\mathrm{jt}}+\lambda \text { PopDen }_{\mathrm{jt}}+ \\
& \gamma \text { Teacher }_{\mathrm{ijt}}+\varepsilon_{\mathrm{ijt}}
\end{aligned}
$$

where Score $_{\mathrm{ijt}}$ represents student achievement on a standardized proficiency test in citizenship, mathematics, reading, writing, and science, Score $\mathrm{ijt}_{\mathrm{j}-1}$ is the lagged test score, Voucher $_{\mathrm{ijt}}$ is a dummy variable that equals 1 if the public school is located in the Cleveland area, Minority $\mathrm{y}_{\mathrm{jt}}$ is the percent of minority students in each district, Enrollment is the total number of students in each district, PopDen $\mathrm{jt}_{\mathrm{jt}}$ is the population density of the county for which the district is located, Teacher $r_{i j t}$ is the percentage of teachers highly qualified to teach and $\varepsilon$ is the random error term.

Four of the 12 districts listed in Table 5.1 contained enough observations for a thorough analysis. The Cleveland Municipal and Lakewood City School Districts represent the urban regions for the analysis and the Mentor Exempted Village and Willoughby-Eastlake School Districts represent the relatively rural regions.

The school districts were broken down into urban and rural regions based on population density with Cleveland Municipal and Lakewood City having densities of 6,103 and 10,511 and Mentor Exempted Village and Willoughby-Eastlake having population densities of 1,800 and 2,147. The schools used in the Cleveland Municipal and Lakewood City analysis also have a much higher percentage of minority students, higher poverty rates, and lower median incomes, all common characteristics of urbanized areas. 
Tables 5.2 and 5.3 represent the regression results for the urban school districts and comparable schools for students being tested in the fourth grade for the 2002-03 and 2003-04 school years in the subjects of citizenship, mathematics, reading, science, and writing. Table 5.2 displays the results for the Cleveland Municipal School District and shows that in 2002-03 average student proficiency in the choice region is approximately 11 percent higher for the subjects of citizenship and science when compared to the nonchoice regions. The results for the 2003-04, show that those schools who participate in the voucher program have average proficiency scores in mathematics, science, and writing that are approximately 14 percent higher when compared to the non voucher regions. Table 5.3 displays the regression results for the Lakewood City School District and comparable schools and shows that Lakewood City public schools on average were approximately 8 percent more proficient in science and 7 percent more proficient in writing for the 2002-03 school year when compared to non-voucher regions. In addition, Lakewood City public schools were 7 percent more proficient in reading for the 2003-04 school year.

Tables 5.4 and 5.5 represent the regression results for the rural school districts and comparable schools. Table 5.4 displays the results for the Mentor Exempted Village School District and shows that the voucher coefficient for science in the 2003-04 school year was positive and significant implying that students in the voucher region were on average 5 percent more proficient in this subject area. Voucher was found to be insignificant in all other specifications for this school district. Table 5.5 displays the results for the Willoughby-Eastlake School District. The voucher coefficient is again found to be positive and significant for both citizenship and science for the 2003-04 
school year. The coefficient estimates reveal that students were approximately 5 percent more proficient in citizenship and 6 percent more proficient in science.

The above mentioned tables also display coefficient estimates for the control variables in the analysis. Overall, percent minority is found to be negative and significant in a variety of regressions. Enrollment tends to be insignificant for most cases, however, it is positive and significant in 9 regressions and negative and significant in 1 regression. Population density tends to be insignificant with only 1 positive and significant finding and 6 negative and significant cases. Teacher coefficients are also insignificant in most regressions with 4 negative and significant cases and 3 positive and significant cases.

Table 5.6 displays the results of the pooled regression analysis. The voucher coefficient is found to be positive and significant in all but 1 regression implying that overall, the voucher program has a positive impact on the public schools that face competition for students which this type of school choice creates. ${ }^{85}$

In addition to the above analysis, additional regressions were run using an interaction term created by multiplying the variable Voucher by a new regressor called Rural which equals one if population density is less than $2,200 .{ }^{86}$

\footnotetext{
${ }^{85}$ Table A.11 in the Appendix pulls out the voucher coefficient from each regression in Tables 5.2-5.6 for comparison purposes.

${ }^{86}$ This number was chosen based on the highest population density between the two rural districts. The population density in the Mentor Exempted Village School District is 1,800 and in the Willoughby Eastlake School District the population density is 2,147. Therefore 2,200 was chosen as the cutoff point for rural status.
} 
Table 5.2 Cleveland Municipal $4^{\text {th }}$ Grade Estimation Results: School Years 2002-03 and 2003-04

\begin{tabular}{|c|c|c|c|c|c|c|c|c|c|c|}
\hline Variable & $\begin{array}{c}\text { Citizenship } \\
2002-03\end{array}$ & $\begin{array}{c}\text { Citizenship } \\
\text { 2003-04 }\end{array}$ & $\begin{array}{c}\text { Mathematics } \\
2002-03\end{array}$ & $\begin{array}{c}\text { Mathematics } \\
2003-04\end{array}$ & $\begin{array}{l}\text { Reading } \\
2002-03\end{array}$ & $\begin{array}{l}\text { Reading } \\
2003-04\end{array}$ & $\begin{array}{l}\text { Science } \\
2002-03\end{array}$ & $\begin{array}{l}\text { Science } \\
2003-04\end{array}$ & $\begin{array}{l}\text { Writing } \\
2002-03\end{array}$ & $\begin{array}{c}\text { Writing } \\
2003-04\end{array}$ \\
\hline Constant & $\begin{array}{c}17.1971 \\
(1.61)\end{array}$ & $\begin{array}{c}21.3068 \\
(1.62)\end{array}$ & $\begin{array}{c}2.5149 \\
(0.22)\end{array}$ & $\begin{array}{c}51.1959^{* * * *} \\
(3.45)\end{array}$ & $\begin{array}{l}0.3282 \\
(0.03)\end{array}$ & $\begin{array}{c}23.3952^{*} \\
(1.84)\end{array}$ & $\begin{array}{c}17.3039 \\
(1.29)\end{array}$ & $\begin{array}{c}29.7130 * * \\
(2.09)\end{array}$ & $\begin{array}{c}35.9076 * * * \\
(3.31)\end{array}$ & $\begin{array}{c}54.5280^{* * *} \\
(4.39)\end{array}$ \\
\hline $\begin{array}{c}\text { Score } \\
\text { (previous year) }\end{array}$ & $\begin{array}{c}0.7545^{* * *} \\
(25.11)\end{array}$ & $\begin{array}{c}0.7851^{* * *} \\
(21.96)\end{array}$ & $\begin{array}{c}0.7331 * * * \\
(22.36)\end{array}$ & $\begin{array}{c}0.6508 * * * \\
(16.97)\end{array}$ & $\begin{array}{c}0.7065^{* * *} \\
(21.79)\end{array}$ & $\begin{array}{c}0.7190^{* * *} \\
(20.54)\end{array}$ & $\begin{array}{c}0.7325^{* * *} \\
(23.01)\end{array}$ & $\begin{array}{c}0.7564 * * * \\
(20.24)\end{array}$ & $\begin{array}{c}0.6445^{* * *} \\
(15.50)\end{array}$ & $\begin{array}{c}0.6176^{* * * *} \\
(13.21)\end{array}$ \\
\hline Voucher & $\begin{array}{c}11.3628^{* *} \\
(2.03)\end{array}$ & $\begin{array}{c}9.0260 \\
(1.38)\end{array}$ & $\begin{array}{c}-0.8471 \\
(0.14)\end{array}$ & $\begin{array}{c}13.6833^{*} \\
(1.86)\end{array}$ & $\begin{array}{l}8.0527 \\
(1.37)\end{array}$ & $\begin{array}{c}-4.1580 \\
(0.66)\end{array}$ & $\begin{array}{c}10.8228^{*} \\
(1.66)\end{array}$ & $\begin{array}{c}13.6326^{*} \\
(1.85)\end{array}$ & $\begin{array}{l}8.8687 \\
(1.61)\end{array}$ & $\begin{array}{c}14.3245^{* *} \\
(2.37)\end{array}$ \\
\hline Minority & $\begin{array}{c}-0.0970 \\
(1.17)\end{array}$ & $\begin{array}{c}-0.1472 \\
(1.61)\end{array}$ & $\begin{array}{c}-0.2469 * * \\
(2.76)\end{array}$ & $\begin{array}{c}-0.2813 \\
(2.92)\end{array}$ & $\begin{array}{c}-0.0399 \\
(0.46)\end{array}$ & $\begin{array}{c}-0.3379 * * * \\
(4.12)\end{array}$ & $\begin{array}{c}-0.2315^{* *} \\
(2.77)\end{array}$ & $\begin{array}{c}-0.1989 * * \\
(2.18)\end{array}$ & $\begin{array}{c}-0.2472 * * * \\
(3.36)\end{array}$ & $\begin{array}{c}-0.2043 * * \\
(2.46)\end{array}$ \\
\hline Enrollment & $\begin{array}{c}0.0104 * * \\
(2.14)\end{array}$ & $\begin{array}{l}0.0021 \\
(0.36)\end{array}$ & $\begin{array}{c}-0.0005 \\
(0.10)\end{array}$ & $\begin{array}{c}0.0049 * * \\
(0.82)\end{array}$ & $\begin{array}{c}0.0124^{* *} \\
(2.84)\end{array}$ & $\begin{array}{l}0.0044 \\
(0.76)\end{array}$ & $\begin{array}{l}0.0039 \\
(0.67)\end{array}$ & $\begin{array}{c}0.0010^{*} \\
(1.65)\end{array}$ & $\begin{array}{l}0.0068 \\
(1.36)\end{array}$ & $\begin{array}{l}0.0038 \\
(0.72)\end{array}$ \\
\hline PopDen & $\begin{array}{c}-0.0029 \\
(1.08)\end{array}$ & $\begin{array}{c}-0.0032 \\
(1.00)\end{array}$ & $\begin{array}{c}0.0053^{*} \\
(1.84)\end{array}$ & $\begin{array}{c}-0.0040 \\
(1.11)\end{array}$ & $\begin{array}{l}0.0031 \\
(1.11)\end{array}$ & $\begin{array}{l}0.0022 \\
(0.73)\end{array}$ & $\begin{array}{l}0.0004 \\
(0.11)\end{array}$ & $\begin{array}{c}-0.0042 \\
(1.19)\end{array}$ & $\begin{array}{c}-0.0007 \\
(0.26)\end{array}$ & $\begin{array}{c}-0.0066^{* *} \\
(2.21)\end{array}$ \\
\hline Teacher & $\begin{array}{l}0.0274 \\
(0.82)\end{array}$ & $\begin{array}{c}0.0805^{* *} \\
(2.19)\end{array}$ & $\begin{array}{l}0.0086 \\
(0.81)\end{array}$ & $\begin{array}{l}0.0291 \\
(0.67)\end{array}$ & $\begin{array}{l}0.0133 \\
(0.41)\end{array}$ & $\begin{array}{l}0.0796 \\
(0.47)\end{array}$ & $\begin{array}{l}0.0154 \\
(0.36)\end{array}$ & $\begin{array}{c}0.0986^{* *} \\
(2.27)\end{array}$ & $\begin{array}{l}0.0328 \\
(0.97)\end{array}$ & $\begin{array}{c}0.1306^{* *} \\
(3.24)\end{array}$ \\
\hline R-Squared & 0.6414 & 0.6305 & 0.6562 & 0.5227 & 0.6358 & 0.5652 & 0.6363 & 0.6132 & 0.4843 & 0.4486 \\
\hline Obs & 359 & 360 & 359 & 359 & 357 & 357 & 356 & 356 & 357 & 357 \\
\hline
\end{tabular}

Notes. t-statistics are in parentheses and the asterisks indicate significance as follows: $* * *=1 \%, * *=5 \%, *=10 \%$. 
Table 5.3 Lakewood City $4^{\text {th }}$ Grade Estimation Results: School Year 2002-03 and 2003-04

\begin{tabular}{|c|c|c|c|c|c|c|c|c|c|c|}
\hline Variable & $\begin{array}{c}\text { Citizenship } \\
\text { 2002-03 }\end{array}$ & $\begin{array}{c}\text { Citizenship } \\
\text { 2003-04 }\end{array}$ & $\begin{array}{l}\text { Mathematics } \\
\text { 2002-03 }\end{array}$ & $\begin{array}{l}\text { Mathematics } \\
\text { 2003-04 }\end{array}$ & $\begin{array}{l}\text { Reading } \\
2002-03\end{array}$ & $\begin{array}{l}\text { Reading } \\
2003-04\end{array}$ & $\begin{array}{l}\text { Science } \\
2002-03\end{array}$ & $\begin{array}{l}\text { Science } \\
2003-04\end{array}$ & $\begin{array}{l}\text { Writing } \\
2002-03\end{array}$ & $\begin{array}{l}\text { Writing } \\
2003-04\end{array}$ \\
\hline Constant & $\begin{array}{c}14.1556^{*} \\
(2.03)\end{array}$ & $\begin{array}{c}17.6317^{* *} \\
(2.18)\end{array}$ & $\begin{array}{c}34.9757^{* * *} \\
(3.93)\end{array}$ & $\begin{array}{c}39.8150 * * * \\
(4.99)\end{array}$ & $\begin{array}{c}21.0988 * * * \\
(3.82)\end{array}$ & $\begin{array}{c}40.5422 * * * \\
(5.24)\end{array}$ & $\begin{array}{c}20.4971 * * \\
(2.58)\end{array}$ & $\begin{array}{c}29.0997 * * * \\
(4.02)\end{array}$ & $\begin{array}{c}51.3252 * * * \\
(6.35)\end{array}$ & $\begin{array}{c}34.9816^{* * * *} \\
(4.32)\end{array}$ \\
\hline $\begin{array}{c}\text { Score } \\
\text { (previous year) }\end{array}$ & $\begin{array}{c}0.7818 * * * \\
(13.05)\end{array}$ & $\begin{array}{c}0.8065^{* * *} \\
(13.02)\end{array}$ & $\begin{array}{c}0.6179^{* * * *} \\
(9.75)\end{array}$ & $\begin{array}{c}0.6438^{* * * *} \\
(9.84)\end{array}$ & $\begin{array}{c}0.7293 * * * \\
(13.89)\end{array}$ & $\begin{array}{c}0.6005 * * * \\
(9.46)\end{array}$ & $\begin{array}{c}0.7250^{* * * *} \\
(12.62)\end{array}$ & $\begin{array}{c}0.6945^{* * * *} \\
(12.89)\end{array}$ & $\begin{array}{c}0.5271 * * * \\
(6.43)\end{array}$ & $\begin{array}{c}0.5435^{* * * *} \\
(7.36)\end{array}$ \\
\hline Voucher & $\begin{array}{c}-0.2022 \\
(0.06)\end{array}$ & $\begin{array}{c}4.3796 \\
(0.88)\end{array}$ & $\begin{array}{c}8.1368 * \\
(1.91)\end{array}$ & $\begin{array}{c}-3.8048 \\
(0.92)\end{array}$ & $\begin{array}{c}3.9603 \\
(1.43)\end{array}$ & $\begin{array}{c}7.3280^{*} \\
(1.93)\end{array}$ & $\begin{array}{c}0.7161 \\
(0.17)\end{array}$ & $\begin{array}{c}-2.1199 \\
(0.52)\end{array}$ & $\begin{array}{c}6.6164^{*} \\
(1.77)\end{array}$ & $\begin{array}{c}-2.4800 \\
(0.89)\end{array}$ \\
\hline Minority & $\begin{array}{c}-0.0022 \\
(0.05)\end{array}$ & $\begin{array}{c}-0.0502 \\
(0.84)\end{array}$ & $\begin{array}{c}-0.1316^{* *} \\
(2.35)\end{array}$ & $\begin{array}{c}-0.1902 * * * \\
(3.61)\end{array}$ & $\begin{array}{c}-0.0577 \\
(1.47)\end{array}$ & $\begin{array}{c}-0.1245^{* *} \\
(2.71)\end{array}$ & $\begin{array}{c}0.0009 \\
(0.02)\end{array}$ & $\begin{array}{c}-0.1310^{* *} \\
(2.23)\end{array}$ & $\begin{array}{c}-0.0772 * \\
(1.71)\end{array}$ & $\begin{array}{c}-0.0495 \\
(1.36)\end{array}$ \\
\hline Enrollment & $\begin{array}{c}-0.0016 \\
(0.20)\end{array}$ & $\begin{array}{c}-0.0056 \\
(0.65)\end{array}$ & $\begin{array}{c}-0.0034 \\
(0.32)\end{array}$ & $\begin{array}{c}-0.0054 \\
(0.62)\end{array}$ & $\begin{array}{c}0.0052 \\
(0.77)\end{array}$ & $\begin{array}{c}-0.0046 \\
(0.53)\end{array}$ & $\begin{array}{c}0.0040 \\
(0.37)\end{array}$ & $\begin{array}{c}-0.0011 \\
(0.13)\end{array}$ & $\begin{array}{c}-0.0154 * * \\
(2.02)\end{array}$ & $\begin{array}{c}-0.0014 \\
(0.22)\end{array}$ \\
\hline PopDen & $\begin{array}{c}-0.0008 \\
(1.43)\end{array}$ & $\begin{array}{c}-0.0006 \\
(0.80)\end{array}$ & $\begin{array}{c}-0.0001 \\
(1.19)\end{array}$ & $\begin{array}{c}0.0002 \\
(0.29)\end{array}$ & $\begin{array}{c}-0.0006 \\
(1.23)\end{array}$ & $\begin{array}{c}-0.0013 * * \\
(2.43)\end{array}$ & $\begin{array}{c}-0.0005 \\
(0.71)\end{array}$ & $\begin{array}{c}-0.0004 \\
(0.71)\end{array}$ & $\begin{array}{c}-0.0012^{* *} \\
(2.20)\end{array}$ & $\begin{array}{c}0.0004 \\
(1.02)\end{array}$ \\
\hline Teacher & $\begin{array}{c}0.0091 \\
(0.39)\end{array}$ & $\begin{array}{c}-0.0513 \\
(1.29)\end{array}$ & $\begin{array}{c}-0.0710^{* *} \\
(2.11)\end{array}$ & $\begin{array}{c}-0.0723 * * \\
(2.23)\end{array}$ & $\begin{array}{c}0.0077 \\
(0.33)\end{array}$ & $\begin{array}{c}-0.0308 \\
(1.11)\end{array}$ & $\begin{array}{c}-0.0576 \\
(1.42)\end{array}$ & $\begin{array}{c}-0.0179 \\
(0.59)\end{array}$ & $\begin{array}{c}-0.0202 \\
(0.82)\end{array}$ & $\begin{array}{c}-0.0022 \\
(0.13)\end{array}$ \\
\hline R-Squared & 0.6061 & 0.5928 & 0.5116 & 0.5593 & 0.6227 & 0.5018 & 0.5699 & 0.5901 & 0.3669 & 0.3859 \\
\hline Obs & 157 & 157 & 157 & 157 & 157 & 157 & 157 & 157 & 157 & 157 \\
\hline
\end{tabular}

Notes. t-statistics are in parentheses and the asterisks indicate significance as follows: $* * *=1 \%, * *=5 \%, *=10 \%$. 
Table 5.4 Mentor Exempted Village $4^{\text {th }}$ Grade Estimation Results: School Year 2002-03 and 2003-04

\begin{tabular}{|c|c|c|c|c|c|c|c|c|c|c|}
\hline Variable & $\begin{array}{l}\text { Citizenship } \\
\text { 2002-03 }\end{array}$ & $\begin{array}{l}\text { Citizenship } \\
\text { 2003-04 }\end{array}$ & $\begin{array}{c}\text { Mathematics } \\
\text { 2002-03 }\end{array}$ & $\begin{array}{c}\text { Mathematics } \\
\text { 2003-04 }\end{array}$ & $\begin{array}{l}\text { Reading } \\
2002-03\end{array}$ & $\begin{array}{l}\text { Reading } \\
2003-04\end{array}$ & $\begin{array}{l}\text { Science } \\
2002-03\end{array}$ & $\begin{array}{l}\text { Science } \\
2003-04\end{array}$ & $\begin{array}{l}\text { Writing } \\
2002-03\end{array}$ & $\begin{array}{l}\text { Writing } \\
2003-04\end{array}$ \\
\hline Constant & $\begin{array}{c}3.4080 \\
(0.09)\end{array}$ & $\begin{array}{c}48.5184 \\
(1.26)\end{array}$ & $\begin{array}{c}60.0448 \\
(1.32)\end{array}$ & $\begin{array}{c}56.5683 * * \\
(2.33)\end{array}$ & $\begin{array}{c}45.7408^{* *} \\
(2.23)\end{array}$ & $\begin{array}{c}43.8228^{* *} \\
(2.04)\end{array}$ & $\begin{array}{l}2.2476 \\
(0.07)\end{array}$ & $\begin{array}{c}58.7293^{*} \\
(1.71)\end{array}$ & $\begin{array}{c}44.8672^{*} \\
(1.89)\end{array}$ & $\begin{array}{c}34.7266 \\
(1.25)\end{array}$ \\
\hline $\begin{array}{c}\text { Score } \\
\text { (previous year) }\end{array}$ & $\begin{array}{c}0.7036 * * * \\
(9.15)\end{array}$ & $\begin{array}{c}0.6916^{* * * *} \\
(10.27)\end{array}$ & $\begin{array}{c}0.6053 * * * \\
(8.28)\end{array}$ & $\begin{array}{c}0.5443 * * * \\
(7.24)\end{array}$ & $\begin{array}{l}0.5392 * * * \\
\quad(6.55)\end{array}$ & $\begin{array}{l}0.5622 * * * \\
(9.27)\end{array}$ & $\begin{array}{c}0.6695 * * * \\
(7.19)\end{array}$ & $\begin{array}{l}0.4981 * * * \\
(8.51)\end{array}$ & $\begin{array}{c}0.4305 * * * \\
(3.99)\end{array}$ & $\begin{array}{c}0.4302 * * * \\
\quad(5.37)\end{array}$ \\
\hline Voucher & $\begin{array}{c}-0.0481 \\
(0.03)\end{array}$ & $\begin{array}{c}2.4172 \\
(1.22)\end{array}$ & $\begin{array}{c}-1.0311 \\
(0.44)\end{array}$ & $\begin{array}{l}1.6629 \\
(0.91)\end{array}$ & $\begin{array}{c}0.7441 \\
(0.45)\end{array}$ & $\begin{array}{l}1.1635 \\
(0.90)\end{array}$ & $\begin{array}{c}-1.2216 \\
(0.49)\end{array}$ & $\begin{array}{c}5.0548 * * \\
(2.73)\end{array}$ & $\begin{array}{c}-1.7666 \\
(1.38)\end{array}$ & $\begin{array}{c}0.2997 \\
(0.21)\end{array}$ \\
\hline Minority & $\begin{array}{c}0.1789 \\
(0.64)\end{array}$ & $\begin{array}{c}-0.6882 * * \\
(2.68)\end{array}$ & $\begin{array}{c}0.2419 \\
(0.70)\end{array}$ & $\begin{array}{c}-0.5025^{* *} \\
(2.02)\end{array}$ & $\begin{array}{c}0.2321 \\
(1.02)\end{array}$ & $\begin{array}{c}-0.5254 * * \\
(2.48)\end{array}$ & $\begin{array}{c}0.4379 \\
(1.26)\end{array}$ & $\begin{array}{c}-0.3765 \\
(1.54)\end{array}$ & $\begin{array}{c}-0.2265 \\
(0.94)\end{array}$ & $\begin{array}{c}-0.3751^{*} \\
(1.85)\end{array}$ \\
\hline Enrollment & $\begin{array}{c}0.0107 * * \\
(2.26)\end{array}$ & $\begin{array}{c}-0.0005 \\
(0.09)\end{array}$ & $\begin{array}{c}0.0184 * * \\
(2.67)\end{array}$ & $\begin{array}{c}0.0022 \\
(0.41)\end{array}$ & $\begin{array}{c}0.0052 \\
(0.95)\end{array}$ & $\begin{array}{c}-0.0003 \\
(0.06)\end{array}$ & $\begin{array}{c}0.0051 \\
(0.64)\end{array}$ & $\begin{array}{c}0.0046 \\
(0.75)\end{array}$ & $\begin{array}{c}0.0110 * * \\
(2.37)\end{array}$ & $\begin{array}{c}0.0007 \\
(0.17)\end{array}$ \\
\hline PopDen & $\begin{array}{c}-0.0008 \\
(1.00)\end{array}$ & $\begin{array}{c}-0.0023 * * \\
(2.81)\end{array}$ & $\begin{array}{c}-0.0021 * * \\
(2.34)\end{array}$ & $\begin{array}{c}-0.0011 \\
(1.25)\end{array}$ & $\begin{array}{c}-0.0008 \\
(1.04)\end{array}$ & $\begin{array}{c}-0.0019^{* *} \\
(3.57)\end{array}$ & $\begin{array}{c}-0.0007 \\
(0.61)\end{array}$ & $\begin{array}{c}-0.0008 \\
(0.96)\end{array}$ & $\begin{array}{c}-0.0004 \\
(0.57)\end{array}$ & $\begin{array}{c}-0.0007 \\
(1.06)\end{array}$ \\
\hline Teacher & $\begin{array}{c}0.1205 \\
(0.38)\end{array}$ & $\begin{array}{c}-0.1903 \\
(0.51)\end{array}$ & $\begin{array}{c}-0.3719 \\
(0.85)\end{array}$ & $\begin{array}{c}-0.1357 \\
(0.60)\end{array}$ & $\begin{array}{c}-0.0945 \\
(0.48)\end{array}$ & $\begin{array}{c}-0.0046 \\
(0.02)\end{array}$ & $\begin{array}{c}0.1631 \\
(0.49)\end{array}$ & $\begin{array}{c}-0.1558 \\
(0.47)\end{array}$ & $\begin{array}{c}0.0307 \\
(0.14)\end{array}$ & $\begin{array}{c}0.1821 \\
(0.67)\end{array}$ \\
\hline R-Squared & 0.4562 & 0.4890 & 0.4791 & 0.5046 & 0.3722 & 0.5042 & 0.4176 & 0.4084 & 0.2090 & 0.2214 \\
\hline Obs & 132 & 132 & 132 & 132 & 132 & 132 & 132 & 132 & 132 & 132 \\
\hline
\end{tabular}

Notes. t-statistics are in parentheses and the asterisks indicate significance as follows: $* * *=1 \%, * *=5 \%, *=10 \%$. 
Table 5.5 Willoughby-Eastlake $4^{\text {th }}$ Grade Estimation Results: School Year 2002-03 and 2003-04

\begin{tabular}{|c|c|c|c|c|c|c|c|c|c|c|}
\hline Variable & $\begin{array}{c}\text { Citizenship } \\
\text { 2002-03 }\end{array}$ & $\begin{array}{c}\text { Citizenship } \\
\text { 2003-04 }\end{array}$ & $\begin{array}{l}\text { Mathematics } \\
\text { 2002-03 }\end{array}$ & $\begin{array}{c}\text { Mathematics } \\
\text { 2003-04 }\end{array}$ & $\begin{array}{l}\text { Reading } \\
2002-03\end{array}$ & $\begin{array}{l}\text { Reading } \\
2003-04\end{array}$ & $\begin{array}{l}\text { Science } \\
2002-03\end{array}$ & $\begin{array}{l}\text { Science } \\
2003-04\end{array}$ & $\begin{array}{l}\text { Writing } \\
2002-03\end{array}$ & $\begin{array}{l}\text { Writing } \\
2003-04\end{array}$ \\
\hline Constant & $\begin{array}{c}19.4575^{* *} \\
(3.36)\end{array}$ & $\begin{array}{c}46.2733 * * * \\
(3.62)\end{array}$ & $\begin{array}{c}31.3693 * * \\
(2.86)\end{array}$ & $\begin{array}{c}43.0849 * * * \\
(3.74)\end{array}$ & $\begin{array}{c}36.7542 * * * \\
(4.78)\end{array}$ & $\begin{array}{c}46.4948 * * * \\
(7.21)\end{array}$ & $\begin{array}{c}22.7827^{*} \\
(1.66)\end{array}$ & $\begin{array}{c}48.6928 * * * \\
(4.36)\end{array}$ & $\begin{array}{c}32.7259 * * \\
(2.71)\end{array}$ & $\begin{array}{c}48.6797 * * * \\
(6.59)\end{array}$ \\
\hline $\begin{array}{c}\text { Score } \\
\text { (previous year) }\end{array}$ & $\begin{array}{c}0.7051 * * * \\
(10.00)\end{array}$ & $\begin{array}{c}0.6504 * * * \\
(8.46)\end{array}$ & $\begin{array}{c}0.7145^{* * * *} \\
\quad(9.09)\end{array}$ & $\begin{array}{l}0.5552 * * * \\
\quad(8.22)\end{array}$ & $\begin{array}{c}0.6327 * * * \\
(7.78)\end{array}$ & $\begin{array}{c}0.5211 * * * \\
(8.70)\end{array}$ & $\begin{array}{c}0.7255^{* * *} \\
\quad(9.59)\end{array}$ & $\begin{array}{c}0.5037 * * * \\
(8.34)\end{array}$ & $\begin{array}{c}0.5699 * * * \\
\quad(5.18)\end{array}$ & $\begin{array}{c}0.5405^{* * *} \\
(6.84)\end{array}$ \\
\hline Voucher & $\begin{array}{c}-1.3252 \\
(0.52)\end{array}$ & $\begin{array}{c}5.1835^{*} \\
(1.81)\end{array}$ & $\begin{array}{l}1.5782 \\
(0.49)\end{array}$ & $\begin{array}{c}2.4937 \\
(0.96)\end{array}$ & $\begin{array}{l}3.8385 \\
(1.56)\end{array}$ & $\begin{array}{c}-0.6995 \\
(0.35)\end{array}$ & $\begin{array}{l}1.2174 \\
(0.37)\end{array}$ & $\begin{array}{c}6.1016^{* * *} \\
(2.08)\end{array}$ & $\begin{array}{c}-1.9877 \\
(1.04)\end{array}$ & $\begin{array}{c}2.3475 \\
(1.22)\end{array}$ \\
\hline Minority & $\begin{array}{c}-0.1273 \\
(0.44)\end{array}$ & $\begin{array}{c}-0.4587 \\
(1.52)\end{array}$ & $\begin{array}{c}0.0213 \\
(0.07)\end{array}$ & $\begin{array}{c}-0.5089^{*} \\
(1.90)\end{array}$ & $\begin{array}{c}0.1654 \\
(0.65)\end{array}$ & $\begin{array}{c}-0.7472 * * \\
(3.36)\end{array}$ & $\begin{array}{c}0.1713 \\
(0.58)\end{array}$ & $\begin{array}{c}-0.4027 \\
(1.25)\end{array}$ & $\begin{array}{c}-0.2976 \\
(1.08)\end{array}$ & $\begin{array}{c}-0.1812 \\
(0.76)\end{array}$ \\
\hline Enrollment & $\begin{array}{c}0.0133^{*} \\
(1.83)\end{array}$ & $\begin{array}{r}0.0021 \\
(0.39)\end{array}$ & $\begin{array}{c}0.0062 \\
(0.91)\end{array}$ & $\begin{array}{c}0.0060 \\
(1.08)\end{array}$ & $\begin{array}{c}0.0126^{* *} \\
(2.31)\end{array}$ & $\begin{array}{c}0.0054 \\
(1.20)\end{array}$ & $\begin{array}{c}0.0021 \\
(0.32)\end{array}$ & $\begin{array}{c}0.0061 \\
(0.91)\end{array}$ & $\begin{array}{c}0.0061 \\
(1.16)\end{array}$ & $\begin{array}{c}0.0016 \\
(0.72)\end{array}$ \\
\hline PopDen & $\begin{array}{c}0.0008 \\
(0.58)\end{array}$ & $\begin{array}{c}0.0015 \\
(1.09)\end{array}$ & $\begin{array}{c}0.0009 \\
(0.57)\end{array}$ & $\begin{array}{c}0.00002 \\
(0.01)\end{array}$ & $\begin{array}{c}0.0001 \\
(0.09)\end{array}$ & $\begin{array}{c}0.0002 \\
(0.19)\end{array}$ & $\begin{array}{c}0.0007 \\
(0.40)\end{array}$ & $\begin{array}{c}0.0005 \\
(0.30)\end{array}$ & $\begin{array}{c}0.0011 \\
(0.97)\end{array}$ & $\begin{array}{c}0.0007 \\
(0.51)\end{array}$ \\
\hline Teacher & $\begin{array}{c}0.0642 \\
(1.02)\end{array}$ & $\begin{array}{c}-0.1823^{*} \\
(1.64)\end{array}$ & $\begin{array}{c}-0.1493 \\
(1.36)\end{array}$ & $\begin{array}{c}0.0551 \\
(0.52)\end{array}$ & $\begin{array}{c}-0.1562^{* *} \\
(2.15)\end{array}$ & $\begin{array}{c}0.0167 \\
(0.30)\end{array}$ & $\begin{array}{c}0.0856 \\
(0.65)\end{array}$ & $\begin{array}{c}0.0819 \\
(0.77)\end{array}$ & $\begin{array}{c}0.0285 \\
(0.36)\end{array}$ & $\begin{array}{c}0.0723 \\
(1.56)\end{array}$ \\
\hline R-Squared & 0.4922 & 0.4790 & 0.4523 & 0.4950 & 0.4588 & 0.4357 & 0.4605 & 0.3880 & 0.3374 & 0.3653 \\
\hline Obs & 127 & 127 & 127 & 127 & 127 & 127 & 127 & 127 & 127 & 127 \\
\hline
\end{tabular}


Table 5.6 Pooled Estimation Results, All Schools: School Year 2002-03 and 2003-04

\begin{tabular}{|c|c|c|c|c|c|c|c|c|c|c|}
\hline Variable & $\begin{array}{l}\text { Citizenship } \\
\text { 2002-03 }\end{array}$ & $\begin{array}{l}\text { Citizenship } \\
\text { 2003-04 }\end{array}$ & $\begin{array}{l}\text { Mathematics } \\
2002-03\end{array}$ & $\begin{array}{l}\text { Mathematics } \\
\text { 2003-04 }\end{array}$ & $\begin{array}{l}\text { Reading } \\
2002-03\end{array}$ & $\begin{array}{l}\text { Reading } \\
2003-04\end{array}$ & $\begin{array}{l}\text { Science } \\
2002-03\end{array}$ & $\begin{array}{l}\text { Science } \\
2003-04\end{array}$ & $\begin{array}{l}\text { Writing } \\
2002-03\end{array}$ & $\begin{array}{l}\text { Writing } \\
2003-04\end{array}$ \\
\hline Constant & $\begin{array}{c}11.6207^{* * *} \\
(4.14)\end{array}$ & $\begin{array}{c}16.1064^{* * * *} \\
(4.14)\end{array}$ & $\begin{array}{c}19.6344 * * * \\
(5.72)\end{array}$ & $\begin{array}{c}34.0766^{* * *} \\
(5.72)\end{array}$ & $\begin{array}{c}19.4259 * * * \\
(4.14)\end{array}$ & $\begin{array}{c}28.4143^{* * *} \\
\quad(8.18)\end{array}$ & $\begin{array}{c}16.3433 * * * \\
(4.25)\end{array}$ & $\begin{array}{c}24.3638 * * * \\
(6.46)\end{array}$ & $\begin{array}{c}29.7575 * * * \\
(8.35)\end{array}$ & $\begin{array}{c}11.6207^{* * *} \\
(4.14)\end{array}$ \\
\hline $\begin{array}{c}\text { Score } \\
\text { (previous year) }\end{array}$ & $\begin{array}{c}0.7744 * * * \\
(35.46)\end{array}$ & $\begin{array}{c}0.7640 * * * \\
(29.34)\end{array}$ & $\begin{array}{c}0.7327 * * * \\
(29.74)\end{array}$ & $\begin{array}{c}0.6359 * * * \\
(24.01)\end{array}$ & $\begin{array}{c}0.7148 * * * \\
(29.08)\end{array}$ & $\begin{array}{c}0.6597 * * * \\
(26.67)\end{array}$ & $\begin{array}{c}0.7588 * * * \\
(32.17)\end{array}$ & $\begin{array}{c}0.7007 * * * \\
(29.09)\end{array}$ & $\begin{array}{c}0.5897 * * * \\
(17.88)\end{array}$ & $\begin{array}{c}0.7744 * * * \\
(35.46)\end{array}$ \\
\hline Voucher & $\begin{array}{c}3.2339 * * \\
(3.03)\end{array}$ & $\begin{array}{c}4.7080^{* * *} \\
(4.06)\end{array}$ & $\begin{array}{c}4.8560 * * \\
(3.61)\end{array}$ & $\begin{array}{c}2.6084 * * \\
(2.02)\end{array}$ & $\begin{array}{c}9.0622 * * * \\
(8.34)\end{array}$ & $\begin{array}{c}0.8756 \\
(0.84)\end{array}$ & $\begin{array}{c}4.4946^{* *} \\
(3.23)\end{array}$ & $\begin{array}{c}6.3562 * * * \\
(4.75)\end{array}$ & $\begin{array}{c}0.4252 * * \\
(0.43)\end{array}$ & $\begin{array}{c}3.2339 * * \\
(3.03)\end{array}$ \\
\hline Minority & $\begin{array}{c}-0.0988 * * * \\
(4.31)\end{array}$ & $\begin{array}{c}-0.0850 * * * \\
(3.46)\end{array}$ & $\begin{array}{c}-0.1193 * * * \\
\quad(5.27)\end{array}$ & $\begin{array}{c}-0.1490 * * * \\
\quad(5.27)\end{array}$ & $\begin{array}{c}-0.0627 * * \\
(2.85)\end{array}$ & $\begin{array}{c}-0.1008 * * * \\
(5.26)\end{array}$ & $\begin{array}{c}-0.0908 * * * \\
(3.34)\end{array}$ & $\begin{array}{c}-0.1646^{* * * *} \\
(6.34)\end{array}$ & $\begin{array}{c}-0.0721 * * * \\
(3.92)\end{array}$ & $\begin{array}{c}-0.0988 * * * \\
(4.31)\end{array}$ \\
\hline Enrollment & $\begin{array}{c}0.0088^{* *} \\
(2.92)\end{array}$ & $\begin{array}{c}-0.0001 \\
(0.03)\end{array}$ & $\begin{array}{c}0.0004^{* *} \\
(1.13)\end{array}$ & $\begin{array}{c}0.0030 * * \\
(0.90)\end{array}$ & $\begin{array}{c}0.0106 * * * \\
(3.66)\end{array}$ & $\begin{array}{c}-0.0023 \\
(0.69)\end{array}$ & $\begin{array}{c}0.0041 \\
(1.07)\end{array}$ & $\begin{array}{c}0.0056 \\
(1.55)\end{array}$ & $\begin{array}{c}0.0007 \\
(0.24)\end{array}$ & $\begin{array}{c}0.0088 * * \\
(2.92)\end{array}$ \\
\hline PopDen & $\begin{array}{c}-0.0006 \\
(1.55)\end{array}$ & $\begin{array}{c}-0.0011 * * \\
(3.27)\end{array}$ & $\begin{array}{c}-0.0003 \\
(0.89)\end{array}$ & $\begin{array}{c}-0.0004 \\
(1.40)\end{array}$ & $\begin{array}{c}-0.0006 \\
(1.55)\end{array}$ & $\begin{array}{c}-0.0009 * * * \\
(3.71)\end{array}$ & $\begin{array}{c}-0.0003 \\
(0.77)\end{array}$ & $\begin{array}{c}-0.0011^{* *} \\
(3.05)\end{array}$ & $\begin{array}{c}-0.0005^{*} \\
(1.91)\end{array}$ & $\begin{array}{c}-0.0006 \\
(1.55)\end{array}$ \\
\hline Teacher & $\begin{array}{c}-0.0047 \\
(0.25)\end{array}$ & $\begin{array}{l}0.0121 \\
(0.42)\end{array}$ & $\begin{array}{c}-0.0295 \\
(1.23)\end{array}$ & $\begin{array}{c}-0.0201 \\
(0.73)\end{array}$ & $\begin{array}{c}-0.0002 \\
(0.64)\end{array}$ & $\begin{array}{c}-0.0443 * \\
(1.70)\end{array}$ & $\begin{array}{c}-0.0376 \\
(1.27)\end{array}$ & $\begin{array}{c}-0.0307 \\
(1.12)\end{array}$ & $\begin{array}{c}0.0638^{* *} \\
(2.80)\end{array}$ & $\begin{array}{c}-0.0047 \\
(0.25)\end{array}$ \\
\hline R-Squared & 0.7822 & 0.7641 & 0.7290 & 0.6994 & 0.7433 & 0.7106 & 0.7355 & 0.7507 & 0.5943 & 0.5555 \\
\hline Obs & 773 & 773 & 775 & 781 & 773 & 773 & 772 & 772 & 773 & 773 \\
\hline
\end{tabular}

Notes. t-statistics are in parentheses and the asterisks indicate significance as follows: $* * *=1 \%, * *=5 \%, *=10 \%$. 
Table 5.7 Pooled Estimation Results with Interaction Term: School Years 2002-03 and 2003-04

\begin{tabular}{|c|c|c|c|c|c|c|c|c|c|c|}
\hline Variable & $\begin{array}{l}\text { Citizenship } \\
2002-03\end{array}$ & $\begin{array}{l}\text { Citizenship } \\
2003-04\end{array}$ & $\begin{array}{l}\text { Mathematics } \\
2002-03\end{array}$ & $\begin{array}{l}\text { Mathematics } \\
2003-04\end{array}$ & $\begin{array}{l}\text { Reading } \\
2002-03\end{array}$ & $\begin{array}{l}\text { Reading } \\
2003-04\end{array}$ & $\begin{array}{l}\text { Science } \\
2002-03\end{array}$ & $\begin{array}{l}\text { Science } \\
2003-04\end{array}$ & $\begin{array}{l}\text { Writing } \\
2002-03\end{array}$ & $\begin{array}{l}\text { Writing } \\
2003-04\end{array}$ \\
\hline Constant & $\begin{array}{c}14.1257 * * * \\
(4.12)\end{array}$ & $\begin{array}{c}9.8782 * * \\
(2.24)\end{array}$ & $\begin{array}{c}17.7568 * * * \\
(4.52)\end{array}$ & $\begin{array}{c}21.6677 * * * \\
(8.23)\end{array}$ & $\begin{array}{c}19.6549 * * * \\
(5.73)\end{array}$ & $\begin{array}{c}27.1359 * * * \\
(7.17)\end{array}$ & $\begin{array}{c}17.0776^{* * *} \\
(3.87)\end{array}$ & $\begin{array}{c}24.7446 * * * \\
(5.48)\end{array}$ & $\begin{array}{c}32.1222 * * * \\
(7.59)\end{array}$ & $\begin{array}{c}28.9570 * * * \\
(7.40)\end{array}$ \\
\hline $\begin{array}{c}\text { Score } \\
\text { (previous year) }\end{array}$ & $\begin{array}{l}0.7626 * * * \\
(29.34)\end{array}$ & $\begin{array}{c}0 . .7697 * * * \\
(28.00)\end{array}$ & $\begin{array}{c}0.7127 * * * \\
(27.94)\end{array}$ & $\begin{array}{c}0.7153 * * * \\
(30.69)\end{array}$ & $\begin{array}{c}0.6970 * * * \\
(28.18)\end{array}$ & $\begin{array}{c}0.6652 * * * \\
(25.96)\end{array}$ & $\begin{array}{c}0.7390 * * * \\
(29.77)\end{array}$ & $\begin{array}{c}0.7081 * * * \\
(29.09)\end{array}$ & $\begin{array}{c}0.6082 * * * \\
(18.23)\end{array}$ & $\begin{array}{c}0.5980 * * * \\
(17.79)\end{array}$ \\
\hline Voucher & $\begin{array}{c}6.1740 * * * \\
(3.39)\end{array}$ & $\begin{array}{c}0.7565 \\
(0.38)\end{array}$ & $\begin{array}{c}6.9211 * * \\
(3.45)\end{array}$ & $\begin{array}{c}-2.6679 \\
(1.44)\end{array}$ & $\begin{array}{c}12.8566^{* * * *} \\
(7.35)\end{array}$ & $\begin{array}{c}-0.4790 \\
(0.28)\end{array}$ & $\begin{array}{c}7.7270 * * * \\
(3.46)\end{array}$ & $\begin{array}{c}5.6104 * * \\
(2.37)\end{array}$ & $\begin{array}{c}5.3958 * * * \\
(3.34)\end{array}$ & $\begin{array}{c}-1.1582 \\
(0.71)\end{array}$ \\
\hline Minority & $\begin{array}{c}-0.1117 * * * \\
(4.77)\end{array}$ & $\begin{array}{c}-0.0064 * * \\
(2.48)\end{array}$ & $\begin{array}{c}-0.1217 * * * \\
(5.09)\end{array}$ & $\begin{array}{c}-0.0050 \\
(0.95)\end{array}$ & $\begin{array}{c}-0.0725^{* *} \\
(3.18)\end{array}$ & $\begin{array}{c}-0.0950 * * * \\
(4.67)\end{array}$ & $\begin{array}{c}-0.1024 * * * \\
(3.70)\end{array}$ & $\begin{array}{c}-0.1627 * * * \\
(6.10)\end{array}$ & $\begin{array}{c}-0.1232 * * * \\
(5.88)\end{array}$ & $\begin{array}{c}-0.0680 * * * \\
(3.51)\end{array}$ \\
\hline Enrollment & $\begin{array}{c}0.0092 * * \\
(3.05)\end{array}$ & $\begin{array}{c}-0.0008 \\
(0.23)\end{array}$ & $\begin{array}{l}0.0041 \\
(1.16)\end{array}$ & $\begin{array}{c}0.0008 \\
(0.27)\end{array}$ & $\begin{array}{c}-0.0107 * * * \\
(3.82)\end{array}$ & $\begin{array}{c}-0.0025 \\
(0.75)\end{array}$ & $\begin{array}{c}0.0044 \\
(1.16)\end{array}$ & $\begin{array}{c}0.0055 \\
(1.56)\end{array}$ & $\begin{array}{c}0.0039 \\
(1.30)\end{array}$ & $\begin{array}{c}0.0006 \\
(0.20)\end{array}$ \\
\hline PopDen & $\begin{array}{c}-0.0011 * \\
(1.85)\end{array}$ & $\begin{array}{c}-0.0001 \\
(0.20)\end{array}$ & $\begin{array}{c}-0.00003 \\
(0.006)\end{array}$ & $\begin{array}{c}-0.0001 \\
(0.25)\end{array}$ & $\begin{array}{c}-0.0004 \\
(0.65)\end{array}$ & $\begin{array}{c}-0.0007 * \\
(1.71)\end{array}$ & $\begin{array}{c}-0.0005 \\
(0.72)\end{array}$ & $\begin{array}{c}-0.0012 * * \\
(1.98)\end{array}$ & $\begin{array}{c}-0.0004 \\
(0.79)\end{array}$ & $\begin{array}{c}-0.0004 \\
(0.92)\end{array}$ \\
\hline Teacher & $\begin{array}{c}0.0024 \\
(0.12)\end{array}$ & $\begin{array}{c}0.0140 \\
(0.49)\end{array}$ & $\begin{array}{c}-0.0213 \\
(0.92)\end{array}$ & $\begin{array}{c}-0.0008 \\
(0.16)\end{array}$ & $\begin{array}{c}-0.0022^{*} \\
(0.12)\end{array}$ & $\begin{array}{c}0.0435^{*} \\
(1.66)\end{array}$ & $\begin{array}{c}-0.0317 \\
(1.08)\end{array}$ & $\begin{array}{c}-0.0287 \\
(1.04)\end{array}$ & $\begin{array}{c}-0.0147 \\
(0.69)\end{array}$ & $\begin{array}{c}0.0616^{* *} \\
(2.66)\end{array}$ \\
\hline Rural & $\begin{array}{c}-0.6744 \\
(0.44)\end{array}$ & $\begin{array}{c}4.5568 * * \\
(2.68)\end{array}$ & $\begin{array}{c}3.8607 * * \\
(2.19)\end{array}$ & $\begin{array}{c}3.8706^{* *} \\
\quad(2.41)\end{array}$ & $\begin{array}{c}2.4602 \\
(1.64)\end{array}$ & $\begin{array}{c}0.4375 \\
(0.32)\end{array}$ & $\begin{array}{l}1.6901 \\
(0.89)\end{array}$ & $\begin{array}{c}-1.1402 \\
(0.66)\end{array}$ & $\begin{array}{l}1.1421 \\
(0.79)\end{array}$ & $\begin{array}{c}-0.4870 \\
(0.70)\end{array}$ \\
\hline Rural*Voucher & $\begin{array}{c}-6.1188 * * \\
(2.85)\end{array}$ & $\begin{array}{c}4.4592 * * \\
\quad(1.94)\end{array}$ & $\begin{array}{c}-8.5664 * * * \\
(3.55)\end{array}$ & $\begin{array}{c}7.9671 * * * \\
(3.73)\end{array}$ & $\begin{array}{c}11.6718 * * * \\
(5.61)\end{array}$ & $\begin{array}{c}2.6355 \\
(1.37)\end{array}$ & $\begin{array}{c}-9.1068 * * * \\
(3.34)\end{array}$ & $\begin{array}{c}2.8106 \\
(1.10)\end{array}$ & $\begin{array}{c}6.2798 * * * \\
(3.57)\end{array}$ & $\begin{array}{c}4.2525^{* *} \\
(2.33)\end{array}$ \\
\hline R-Squared & 0.7839 & 0.6655 & 0.7349 & 0.8593 & 0.7532 & 0.7111 & 0.7395 & 0.7512 & 0.5992 & 0.5577 \\
\hline Obs & 773 & 773 & 775 & 787 & 773 & 773 & 772 & 772 & 773 & 773 \\
\hline
\end{tabular}

Notes. t-statistics are in parentheses and the asterisks indicate significance as follows: $* * *=1 \%, * *=5 \%, *=10$. 
The new regression equations is as follows,

Score $_{\mathrm{ijt}}=\alpha+\varphi$ Score $_{\mathrm{ijt}-1}+\sigma \operatorname{Voucher}_{\mathrm{ijt}}+\mu \operatorname{Rural}_{\mathrm{ijt}}+\theta$ Minority $_{\mathrm{jt}}+\omega$ Rural$^{*}$ Voucher $_{\mathrm{ijt}}+$ $\delta$ Enrollment $_{\mathrm{jt}}+\lambda$ PopDen $_{\mathrm{jt}}+\gamma$ Teacher $_{\mathrm{ijt}}+\varepsilon_{\mathrm{ijt}}$

Equation 5.4 includes both a slope dummy and an intercept dummy. The intercept will be $\alpha$ when Rural $=0$ and will be $(\alpha+\mu)$ when Rural $=1$. In addition, the slope of Score with respect to Voucher will be $\sigma$ when Rural $=0$ and Voucher $=1$ and $(\sigma+\omega)$ when Rural $=1$ and Voucher $=1$. The results for the 2002-03 and 2003-04 school years are reported in Table 5.7. When analyzing the 2002-03 school year, it is shown that for the subjects of mathematics and reading, Rural is positive and significant implying that we could reject the null hypothesis of no difference in test scores due to location in regards to urban versus rural status holding constant the other variables in the equation. In addition, the slope dummy, Rural*Voucher, is negative and significant for all subjects revealing that rural school districts experience less of an impact from the competition that the voucher system creates when compared to urban school districts. The results for the 2003-04 school year are uninteresting in that the variable of interest, Voucher, becomes insignificant in all but one case.

\subsection{Conclusion}

Finding a solution to improving the plight of low performing urban schools is an ongoing and highly controversial political issue. The federal No Child Left Behind Act of 2001, (NCLB) is the most recent piece of legislation that has been implemented in an attempt to 
improve educational outcomes in low performing schools. This legislation, which promotes school choice in the form of open enrollment and vouchers was developed in part to create competition in the education market. More specifically, this act addresses the idea that a universal voucher program would improve student achievement through the induced private school competition that would be created, forcing weaker public schools out of the market. In other words, creating choices for parents keeps only the high quality schools in business while failing schools are forced to either improve or leave the market altogether. The results of this paper show that the urban public schools in the voucher region experience average proficiency scores that are higher for certain subjects when compared to average proficiency scores of public schools in non-voucher regions throughout the state. This implies that the NCLB act, implemented to help failing low-income urban public schools, has been successful in creating competition for students which in turn has improved student outcomes. Therefore, from a policy standpoint, this program is achieving its goal.

Smaller, rural schools are also seeing average test scores rise with the implementation of the voucher program within the region. This result, although not a direct goal of the NCLB act, is a finding consistent with the belief that competition for students will create an atmosphere conducive to innovation in public schools leading to improved student outcomes.

The implementation of school choice throughout the United States has been growing substantially over the past decade. It is important to analyze the effects of competition that school choice creates in terms of the educational outcomes of the students who are participating in a school choice program and in terms of the students 
who stay behind in the public schools that are seeing the transfers occurring. Whether or not these public schools improve after a school choice program is implemented gives us a way to measure the effects of competition in the education market. Based on my results, both the urban and rural school districts have incentives to improve after a voucher program has been implemented and thus higher levels of proficiency are the result. 


\section{Chapter 6}

\section{Conclusion and Areas of Future Research}

Education reform in the United States has been and will continue to be a topic of debate for years to come. Policies designed to improve student outcomes have been studied from an economic viewpoint for over a century. Creating an education market for which competition can be implemented to improve public school quality has recently become the newest topic for debate among policymakers. School choice is the most common term used to refer to programs that promote competition in education. Choice comes in many forms, such as private schools, charter schools, vouchers, open enrollment, and tax credit and tax deduction programs. This dissertation contributes to the literature by presenting specific applications of the effects of school choice on student achievement.

These specific applications are contained in the four research chapters of this dissertation. Chapter 2 measures the spillover benefits created by K-12 public education and analyzes how they impact market efficiency. Given the results from the empirical analysis, this chapter also examines how school choice would function in a market for K12 public education. Chapter 3 provides a history of school choice in the United States and discusses how it has developed and changed the education market over the past two decades. The next two chapters focus on specific forms of school choice and present empirical results on the effects of competition on student achievement levels for two different school choice options. Chapter 4 compares for-profit and nonprofit charter schools and analyzes the interaction between the profit motive and the induced competition that is created by this form of school choice. Chapter 5 examines how competition through the implementation of a public voucher program affects public 
school performance by analyzing test scores of students who choose not to participate in the program in both urban and rural regions.

The remainder of the current chapter will (i) summarize the major findings of chapters 2, 4, and 5, (ii) highlight the importance of each finding by relating it to the current literature, and (iii) propose topics of future research. ${ }^{87}$

After Pigou published The Economics of Welfare (1920) almost everyone agreed that externalities create welfare losses unless appropriate taxes or subsidies are instituted to augment private behavior. This idea started to change when Coase (1960) published "The Problem of Social Cost" and pointed out that externalities would create no welfare losses when transactions costs were low and property rights well-defined. Coase also noted that government action is no more perfect than market outcomes, and therefore intervention might actually worsen the externality situation. Buchanan and Stubblebine (1962) also point out that some externalities will be appropriately internalized privately and therefore will not impact market efficiency. Chapter 2 focuses on the idea that the positive externalities created by education could be like those discussed by Buchanan and Stubblebine (1962) and therefore not Pareto-relevant. Using a median voter demand curve model this chapter produces a measure to estimate the degree to which K-12 public education suffers from a positive externality problem. The results indicate that K-12 public education is almost entirely a pure private good creating no Pareto-relevant spillover benefits to the median voter. This implies that arguments for additional government intervention in the provision of public education based on efficiency grounds are unfounded.

\footnotetext{
${ }^{87}$ Chapter 3 deals with the history of school choice and has a concluding paragraph already summarizing its importance to the dissertation.
} 
This chapter makes an important contribution to the literature in that no one has attempted to quantify the spillover benefits of K-12 public education. These findings are also important for policymakers when looking at the impacts of school choice in the education market. Based on the empirical results, market forces are capable of producing the efficient quantity of education given the current amount of subsidization already in place and thus school choice has the potential to increase the current quality of education through effective competition.

There are a few extensions of this line of research that may be worth investigating. First, the finding that K-12 public education is almost entirely a private good leads one to believe that privatizing education could work from a policy standpoint. One issue that could be further examined is the distributional effects of such a system. Second, it would be interesting to apply these results to other countries' reform policies. In particular, how would the conclusions of this paper change if we instead considered the effects of school choice in less developed or developing countries. Clearly my findings suggest very strong implications for the ability of school choice to improve student outcomes. This issue needs to be further examined using empirical studies to convince policymakers of its importance.

Chapter 4 analyzes the impacts of charter schools on student achievement. In particular, this chapter looks at the structure of charter schools to determine whether or not the profit motive in education can work to improve student outcomes. Charter schools are a fairly new phenomenon and therefore the literature has just recently begun to focus on the impacts that this type of school choice has on educational outcomes. Studies show that charter schools are having positive impacts in two ways. First, 
research has shown that charter students typically see gains in achievement after the first year of attendance. Other lines of research focus on the competition that charter schools create for traditional public schools. Studies here are limited, but there is evidence showing a positive impact for traditional public schools from charter school competition.

This chapter makes an important contribution to the literature being the first to compare for-profit and nonprofit charter school student outcomes. Applying the profit motive to education is a fairly new line of research that has invoked much controversy. The structure of for-profit and nonprofit charter schools is modeled by Hoxby (2003) where she finds that for-profit charter schools have greater incentives to improve school quality because of the distribution of the surplus. I test her model and find that for-profit charter schools are seeing higher test scores in two different standardized exams and therefore confirm not only her findings, but also a basic principle of economics, “incentives matter."

Although this study focused on the state of Arizona due to data limitations, as time goes on, more and more states are seeing a larger number of for-profit charter schools develop. Michigan and California are just a few of the states that allow for the development of for-profit charter schools in their charter school laws. The analysis of this chapter could be extended to several other states and for extended time periods as the data becomes available. Also, additional empirical work could focus on the spatial distribution of for-profit charter schools relative to nonprofit and traditional public schools. 
From an economic viewpoint, it is very important to analyze the costs and benefits of all policies designed to improve student outcomes. Chapter 5 analyzes how the introduction of vouchers affects both urban and rural public school performance. More specifically, this chapter analyzes how the competition from private schools created by voucher programs effects achievement levels for those students who stay behind in the public schools.

The current literature typically focuses on the students who choose to participate in the voucher program and analyzes how their current scores compare to students who stay in the public school system. More recent studies are starting to analyze how public schools react to the competition that voucher programs create. The results of this chapter make an important contribution to the literature by making an urban versus rural comparison. One of the main goals of a voucher program is to help improve the plight of low-performing schools, which tend to be found in relatively urbanized areas. The results of this paper suggest that urban public schools are seeing positive impacts from the competition that voucher programs create. In addition, rural public schools in the voucher region are also seeing gains in student achievement, but not in the same magnitude as the urban public schools in the study. These findings give support to the notion that when voucher programs are implemented to help those schools most in need, the goal of improved student performance in these schools is achieved.

Clearly, the debate over whether or not school choice can ultimately be the solution to our educational problems is still an issue that needs extensive work. In order to accurately measure the benefits and costs of implementing competition into the education market, the theory of school choice will need to be further developed. In 
addition, further empirical studies measuring the impacts of school choice on student achievement will need to be undertaken and analyzed in great detail.

Based on the current literature, and the results of this dissertation, the positive aspects of integrating competition into the education market are finally being realized. School choice has made great strides over the past 20 years, but in order for the benefits of choice to be fully realized, options must be made available on a broader scale. Future research on the economics of school choice can help us reach this goal. 


\section{APPENDIX}

\section{Buchanan and Stubblebine’s (1962) derivation of inframarginal externalities.}

For the purposes of this chapter it is important to understand how Buchanan and Stubblebine (1962) make the distinction between marginal and inframarginal externalities, potentially relevant and irrelevant externalities, and Pareto-relevant and Pareto irrelevant externalities. The authors define an externality to exist when,

$$
\mathrm{u}^{\mathrm{A}}=\mathrm{u}^{\mathrm{A}}\left(\mathrm{X}_{1}, \mathrm{X}_{2}, \ldots, \mathrm{X}_{\mathrm{m}}, \mathrm{Y}_{1}\right)
$$

The above equation states that the utility of individual $\mathrm{A}$ depends upon the activities under her own control $\left(\mathrm{X}_{1}, \mathrm{X}_{2}, \ldots, \mathrm{X}_{\mathrm{m}}\right)$ and the activity $\mathrm{Y}_{1}$ which is out of individual's $\mathrm{A}$ control and by definition is under taken by individual $\mathrm{B}$. The next step is to assume that individual A will maximize utility taking $\mathrm{Y}_{1}$ into account and will modify the $\mathrm{X}^{\prime} \mathrm{s}$ as $\mathrm{Y}_{1}$ changes to maintain a state of equilibrium. Therefore, a marginal externality exists when,

$$
u_{Y_{1}}^{A} \neq 0
$$

The lower case u's are employed here to represent the partial derivatives of the utility function. In other words, $u_{Y_{1}}^{A}=\partial \mathrm{u}^{\mathrm{A}} / \partial \mathrm{Y}_{1}$. An inframarginal externality holds at those points where,

$$
u_{Y_{1}}^{A}=0
$$

These classifications can be broken down into economies and diseconomies with a marginal external economy existing when $u_{Y_{1}}^{A}>0$ and a marginal external diseconomy when $u_{Y_{1}}^{A}<0$. An inframarginal external economy exists when for any set of values for $\left(\mathrm{X}_{1}, \mathrm{X}_{2}, \ldots, \mathrm{X}_{\mathrm{m}}\right)$, for example $\left(\mathrm{C}_{1}, \mathrm{C}_{2}, \ldots, \mathrm{C}_{\mathrm{m}}\right)$,

$$
u_{Y_{1}}^{A}=0 \text {, and } \int_{0}^{Y_{1}} u_{Y_{1}}^{A} \mathrm{~d} \mathrm{Y}_{1}>0 .
$$

This is the condition relevant for this chapter which states that even though incremental changes in the extent of B's activity have no affect on A's utility, the total effect of B's action has increased A's utility.

The next step is to distinguish between relevant and irrelevant externalities. To simplify the analysis, assume that B's utility function depends only on variables within her control, including $\mathrm{Y}_{1}$. B's utility function will therefore be represented by,

$$
u^{B}=u^{B}\left(Y_{1}, Y_{2}, \ldots, Y_{m}\right)
$$


The necessary conditions for utility maximization by B are, $u_{Y_{1}}^{B} / u_{Y_{j}}^{B}=f_{Y_{1}}^{B} / f_{Y_{j}}^{B}$, where $Y_{\mathrm{j}}$ represents B's activity in consuming some numeraire commodity or service which is available by hypothesis on equal terms to A. The righthand term represents the marginal rate of substitution in production or exchange faced by B. B's production function is represented by

$$
f^{B}=f^{B}\left(\mathrm{Y}_{1}, \mathrm{Y}_{2}, \ldots, \mathrm{Y}_{\mathrm{m}}\right),
$$

where both inputs and outputs are included as activities. Therefore the right-hand side term represents the marginal cost of the activity $\mathrm{Y}_{1}$ to $\mathrm{B}$.

An externality is considered potentially relevant when the activity generates any desire on the part of the benefited party (A) to change the behavior of the party empowered to take the action (B) through persuasion, compromise, etc. An externality that does not exert this kind of influence is defined as irrelevant.

A relevant marginal externality exists when,

$$
u_{Y_{1}}^{A} \mid Y_{1}=Y_{1}^{*} \neq 0,
$$

where $Y^{*}$ 's are used to represent equilibrium values for the Y's.

When the above equation is greater than zero it is a potentially relevant marginal external economy and a diseconomy when less than zero. A is motivated by B's actions to make some effort to modify this activity, that is, increase the resources devoted to the activity when the equation is positive.

Inframarginal externalities are irrelevant for small changes in B's activity, $\mathrm{Y}_{1}$. However, when large changes are considered, A is motivated to change B's behavior with respect to $\mathrm{Y}_{1}$ except for when,

$$
\begin{gathered}
u_{Y_{1}}^{A} \mid Y_{1}=Y_{1}^{*}=0, \\
\text { and } \mathrm{u}^{\mathrm{A}}\left(\mathrm{C}_{1}, \mathrm{C}_{2}, \ldots, \mathrm{C}_{\mathrm{m}}, Y_{1}^{*}\right) \geq \mathrm{u}^{\mathrm{A}}\left(\mathrm{C}_{1}, \mathrm{C}_{2}, \ldots, \mathrm{C}_{\mathrm{m}}, \mathrm{Y}_{1}\right) \text { for all } \mathrm{Y}_{1} \neq Y_{1}^{*} .
\end{gathered}
$$

When the above equation holds, A has reached an absolute maximum of utility with respect to changes in $Y_{1}$, given any set of values for the X's. In all other cases where inframarginal external economies or diseconomies exist, A will have some desire to modify B's activity.

The above discussion describes the most relevant aspects of Buchanan and Stubblebine's analysis of externalities for this chapter. For additional discussion of Pareto-relevant and Pareto-irrelevant externalities see Buchanan and Stubblebine (1962). 
APPENDIX

Table A.1 Variable Definitions and Data Sources

\begin{tabular}{|l|l|l|}
\hline Variable & Definition & Source \\
\hline E & state education expenditures & A \\
\hline POP & state population & B \\
\hline INCOME & state median disposable income & C \\
\hline DEN & state population density per square mile of land area & C \\
\hline AGE & state median age & B \\
\hline NW & percent of state population non-white & C \\
\hline LESSTHAN18 & percent of state population under 18 & B \\
\hline SALARY & average teacher salary in each state & D, F \\
\hline SCHOOLS & number of schools in each state & E \\
\hline FREELUNCH & $\begin{array}{l}\text { percent of schools participating in the National School Lunch } \\
\text { Program }\end{array}$ & G, H \\
\hline F & federal tax liability & C \\
\hline G & federal grants by state & C \\
\hline
\end{tabular}

\section{Sources}

A: State Government Finances. U.S. Department of Commerce, Bureau of the Census.

B: Census of Population. U.S. Department of Commerce, Bureau of the Census.

C: Statistical Abstract of the United States. U.S. Department of Commerce, Bureau of the Census.

D: Digest of Education Statistics. U.S. Department of Education.

E: National Center for Education Statistics, Common Core of Data. U.S. Department of Education.

F: Estimates of School Statistics, National Education Association.

G: Food and Nutrition Services, U.S. Department of Agriculture.

H: Schools and Staffing Survey, U.S. Department of Education. 
APPENDIX

Table A.2 Estimated Determinants of Student Achievement, 2002-03

Dependent Variable: Average Test Score on the Stanford 9 Exam

\begin{tabular}{|c|c|c|c|c|c|}
\hline & GRADE 2 & GRADE 3 & GRADE 4 & GRADE 5 & $\begin{array}{l}\text { POOLED } \\
\text { GRADES }\end{array}$ \\
\hline Intercept & $\begin{array}{l}-7.82 \\
(0.89)\end{array}$ & $\begin{array}{l}-3.99 \\
(0.47)\end{array}$ & $\begin{array}{l}10.35 \\
(1.35)\end{array}$ & $\begin{array}{l}30.96 * * * \\
(3.86)\end{array}$ & $\begin{array}{l}7.32^{*} \\
(1.73)\end{array}$ \\
\hline $\begin{array}{l}\text { Score } \\
\text { (Previous year) }\end{array}$ & $\begin{array}{l}0.58^{* * *} \\
(13.74)\end{array}$ & $\begin{array}{l}0.69^{* * *} \\
(18.46)\end{array}$ & $\begin{array}{l}0.72^{* * *} \\
(14.61)\end{array}$ & $\begin{array}{l}0.52^{* * * *} \\
(13.62)\end{array}$ & $\begin{array}{l}0.60^{* * *} \\
(28.50)\end{array}$ \\
\hline Percent Minority & $\begin{array}{l}0.18^{* * *} \\
(5.93)\end{array}$ & $\begin{array}{l}0.10^{* *} \\
(3.38)\end{array}$ & $\begin{array}{l}0.13^{* * *} \\
(4.80)\end{array}$ & $\begin{array}{l}0.19^{* * *} \\
(7.56)\end{array}$ & $\begin{array}{l}0.16^{* * *} \\
(11.31)\end{array}$ \\
\hline Income & $\begin{array}{l}0.03 \\
(0.13)\end{array}$ & $\begin{array}{l}-0.12 \\
(0.01)\end{array}$ & $\begin{array}{l}0.28 \\
(1.50)\end{array}$ & $\begin{array}{l}-0.34^{*} \\
(1.89)\end{array}$ & $\begin{array}{l}-0.02 \\
(0.20)\end{array}$ \\
\hline ForProfit & $\begin{array}{l}0.13 \\
(0.07)\end{array}$ & $\begin{array}{l}4.08^{* *} \\
(2.58)\end{array}$ & $\begin{array}{l}-1.09 \\
(0.69)\end{array}$ & $\begin{array}{l}2.55^{*} \\
(1.67)\end{array}$ & $\begin{array}{l}1.65^{* *} \\
(1.95)\end{array}$ \\
\hline$\overline{\mathrm{BA}}$ & $\begin{array}{l}2.19 \\
(0.54)\end{array}$ & $\begin{array}{l}1.34 \\
(0.36)\end{array}$ & $\begin{array}{l}9.72 * * \\
(2.83)\end{array}$ & $\begin{array}{l}-1.99 \\
(0.54)\end{array}$ & $\begin{array}{l}3.97 * * \\
(2.11)\end{array}$ \\
\hline $\mathrm{MA}$ & $\begin{array}{l}4.64 \\
(0.72)\end{array}$ & $\begin{array}{l}-0.34 \\
(0.06)\end{array}$ & $\begin{array}{l}-4.86 \\
(0.88)\end{array}$ & $\begin{array}{l}-0.40 \\
(0.07)\end{array}$ & $\begin{array}{l}-0.21 \\
(0.07)\end{array}$ \\
\hline PHD & $\begin{array}{l}71.14^{* *} \\
(2.21)\end{array}$ & $\begin{array}{l}-20.20 \\
(0.69)\end{array}$ & $\begin{array}{l}-27.06 \\
(0.82)\end{array}$ & $\begin{array}{l}-40.21 \\
(1.58)\end{array}$ & $\begin{array}{l}0.82 \\
(0.05)\end{array}$ \\
\hline $\begin{array}{l}<3 \text { Years } \\
\text { Experience }\end{array}$ & $\begin{array}{l}11.65^{*} \\
(1.84)\end{array}$ & $\begin{array}{l}8.85 \\
(1.54)\end{array}$ & $\begin{array}{l}-25.08^{* *} \\
(4.63)\end{array}$ & $\begin{array}{l}-10.16^{*} \\
(1.75)\end{array}$ & $\begin{array}{l}-3.41 \\
(1.13)\end{array}$ \\
\hline $\begin{array}{l}\text { 4to6 Years } \\
\text { Experience }\end{array}$ & $\begin{array}{l}14.61^{*} \\
(1.92)\end{array}$ & $\begin{array}{l}27.55^{* * *} \\
(4.13)\end{array}$ & $\begin{array}{l}-14.44^{* *} \\
(2.23)\end{array}$ & $\begin{array}{l}-4.35 \\
(0.62)\end{array}$ & $\begin{array}{l}5.34 \\
(1.50)\end{array}$ \\
\hline $\begin{array}{l}>10 \text { Years } \\
\text { Experience }\end{array}$ & $\begin{array}{l}27.70^{* *} \\
(3.70)\end{array}$ & $\begin{array}{l}14.96^{* *} \\
(2.29)\end{array}$ & $\begin{array}{l}-11.43^{*} \\
(1.80)\end{array}$ & $\begin{array}{l}-6.03 \\
(0.80)\end{array}$ & $\begin{array}{l}7.27 * * \\
(2.05)\end{array}$ \\
\hline R-squared & 0.63 & 0.74 & 0.73 & 0.73 & 0.63 \\
\hline Obs & 286 & 249 & 251 & 244 & 1030 \\
\hline
\end{tabular}

Notes. t-statistics are in parentheses and the asterisks indicate significance as follows: $* * *=1 \%, * *=5 \%, *=10 \%$. 
APPENDIX

Table A.3 Estimated Determinants of Student Achievement, 2003-04 Dependent Variable: Average Test Score on the Stanford 9 Exam

\begin{tabular}{|c|c|c|c|c|c|}
\hline & GRADE 2 & GRADE 3 & GRADE 4 & GRADE 5 & $\begin{array}{l}\text { POOLED } \\
\text { GRADES }\end{array}$ \\
\hline Intercept & $\begin{array}{l}0.83 \\
(0.08)\end{array}$ & $\begin{array}{l}-1.47 \\
(0.17)\end{array}$ & $\begin{array}{l}-8.50 \\
(1.16)\end{array}$ & $\begin{array}{l}6.37 \\
(0.81)\end{array}$ & $\begin{array}{l}-0.84 \\
(0.19)\end{array}$ \\
\hline $\begin{array}{l}\text { Score } \\
\text { (Previous year) }\end{array}$ & $\begin{array}{l}0.69 * * * \\
(13.20)\end{array}$ & $\begin{array}{l}0.63 * * * \\
(15.39)\end{array}$ & $\begin{array}{l}0.72 * * * \\
(18.21)\end{array}$ & $\begin{array}{l}0.80^{* * * *} \\
(16.97)\end{array}$ & $\begin{array}{l}0.70^{* * * *} \\
(30.49)\end{array}$ \\
\hline Percent Minority & $\begin{array}{l}0.05 \\
(1.16)\end{array}$ & $\begin{array}{l}0.19 \text { *** } \\
(6.08)\end{array}$ & $\begin{array}{l}0.12^{* * *} \\
(4.11)\end{array}$ & $\begin{array}{l}0.07 * * \\
(2.47)\end{array}$ & $\begin{array}{l}0.11 * * * \\
(6.89)\end{array}$ \\
\hline Income & \begin{tabular}{|l|}
0.32 \\
$(1.28)$
\end{tabular} & $\begin{array}{l}0.14 \\
(0.64)\end{array}$ & $\begin{array}{l}0.27 \\
(1.56)\end{array}$ & $\begin{array}{l}0.09 \\
(0.50)\end{array}$ & $\begin{array}{l}0.23 * * \\
(2.13)\end{array}$ \\
\hline ForProfit & $\begin{array}{l}1.84 \\
(0.89)\end{array}$ & $\begin{array}{l}6.47^{* *} \\
(3.66)\end{array}$ & $\begin{array}{l}2.65^{*} \\
(1.77)\end{array}$ & $\begin{array}{l}2.08 \\
(1.32)\end{array}$ & $\begin{array}{l}3.15^{* *} \\
(3.53)\end{array}$ \\
\hline $\mathrm{BA}$ & $\begin{array}{l}-5.54 \\
(1.33)\end{array}$ & $\begin{array}{l}-4.99 \\
(1.37)\end{array}$ & $\begin{array}{l}4.92^{*} \\
(1.66)\end{array}$ & $\begin{array}{l}0.75 \\
(0.24)\end{array}$ & $\begin{array}{l}-1.31 \\
(0.72)\end{array}$ \\
\hline MA & $\begin{array}{l}-4.46 \\
(0.72)\end{array}$ & $\begin{array}{l}-6.33 \\
(1.25)\end{array}$ & $\begin{array}{l}5.29 \\
(1.22)\end{array}$ & $\begin{array}{l}3.10 \\
(0.62)\end{array}$ & $\begin{array}{l}-0.54 \\
(0.20)\end{array}$ \\
\hline PHD & $\begin{array}{l}38.81 \\
(1.38)\end{array}$ & $\begin{array}{l}-17.28 \\
(0.71)\end{array}$ & $\begin{array}{l}-38.87^{* *} \\
(1.96)\end{array}$ & $\begin{array}{l}-20.09 \\
(0.85)\end{array}$ & $\begin{array}{l}-10.06 \\
(0.81)\end{array}$ \\
\hline $\begin{array}{l}<3 \text { Years } \\
\text { Experience }\end{array}$ & $\begin{array}{l}15.80^{* *} \\
(2.25)\end{array}$ & $\begin{array}{l}10.97^{*} \\
(1.84)\end{array}$ & $\begin{array}{l}7.14 \\
(1.36)\end{array}$ & $\begin{array}{l}-12.37^{* *} \\
(2.39)\end{array}$ & $\begin{array}{l}5.48^{*} \\
(1.81)\end{array}$ \\
\hline $\begin{array}{l}\text { 4to6 Years } \\
\text { Experience }\end{array}$ & $\begin{array}{l}7.50 \\
(0.95)\end{array}$ & $\begin{array}{l}7.71 \\
(1.09)\end{array}$ & $\begin{array}{l}6.33 \\
(1.01)\end{array}$ & $\begin{array}{l}7.78 \\
(1.25)\end{array}$ & $\begin{array}{l}6.35^{*} \\
(1.77)\end{array}$ \\
\hline $\begin{array}{l}>10 \text { Years } \\
\text { Experience }\end{array}$ & $\begin{array}{l}9.24 \\
(1.13)\end{array}$ & $\begin{array}{l}15.31^{* *} \\
(2.27)\end{array}$ & $\begin{array}{l}-0.79 \\
(0.14)\end{array}$ & $\begin{array}{l}-2.37 \\
(0.39)\end{array}$ & $\begin{array}{l}4.99 \\
(1.45)\end{array}$ \\
\hline R-squared & 0.52 & 0.67 & 0.75 & 0.75 & 0.64 \\
\hline Obs & 300 & 289 & 263 & 262 & 1114 \\
\hline
\end{tabular}

Notes. t-statistics are in parentheses and the asterisks indicate significance as follows: $* * *=1 \%,{ }^{* *}=5 \%, *=10 \%$. 


\section{APPENDIX}

Table A.4 Estimated Determinants of Student Achievement, 2002-03, 2003-04

Dependent Variable: Average Test Score on AIMS Exam

\begin{tabular}{|c|c|c|c|c|c|c|}
\hline $3^{\text {rd }}$ Grade & $\begin{array}{l}\text { Meet } \\
2002-03\end{array}$ & $\begin{array}{l}\text { Meet } \\
2003-04\end{array}$ & $\begin{array}{l}\text { Exceed } \\
2002-03\end{array}$ & $\begin{array}{l}\text { Exceed } \\
2003-04\end{array}$ & $\begin{array}{l}\text { Meet + Exceed } \\
2002-03\end{array}$ & $\begin{array}{l}\text { Meet }+ \text { Exceed } \\
2003-04\end{array}$ \\
\hline Intercept & $\begin{array}{l}28.20^{* *} \\
(2.72)\end{array}$ & $\begin{array}{l}32.84 * * \\
(3.07)\end{array}$ & $\begin{array}{l}-15.83^{*} \\
(1.72)\end{array}$ & $\begin{array}{l}4.00^{* *} \\
(0.42)\end{array}$ & $\begin{array}{l}14.77 \\
(1.58)\end{array}$ & $\begin{array}{l}46.62 * * * \\
(3.65)\end{array}$ \\
\hline $\begin{array}{l}\text { Score } \\
\text { (Previous } \\
\text { year) }\end{array}$ & $\begin{array}{l}0.56^{* * *} \\
(9.01)\end{array}$ & $\begin{array}{l}0.72 * * * \\
(13.98)\end{array}$ & $\begin{array}{l}0.55^{* * *} \\
(9.86)\end{array}$ & $\begin{array}{l}0.67 * * * \\
(11.19)\end{array}$ & $\begin{array}{l}0.52 * * * \\
(8.63)\end{array}$ & $\begin{array}{l}0.56^{* * *} \\
(6.31)\end{array}$ \\
\hline $\begin{array}{l}\text { Percent } \\
\text { Minority }\end{array}$ & $\begin{array}{l}-10.24^{* *} \\
(2.48)\end{array}$ & $\begin{array}{l}-5.38 \\
(1.27)\end{array}$ & $\begin{array}{l}-3.75^{* *} \\
(1.37)\end{array}$ & $\begin{array}{l}-7.35^{* *} \\
(2.15)\end{array}$ & $\begin{array}{l}-15.33 * * \\
(2.97)\end{array}$ & $\begin{array}{l}-18.27 * * \\
(2.92)\end{array}$ \\
\hline Income & $\begin{array}{c}0.34 \\
(1.23)\end{array}$ & $\begin{array}{l}-0.04 \\
(1.33)\end{array}$ & $\begin{array}{l}0.33 \\
(1.55)\end{array}$ & $\begin{array}{c}0.06 \\
(0.20)\end{array}$ & $\begin{array}{l}0.70^{*} \\
(2.40)\end{array}$ & $\begin{array}{l}-0.26 \\
(0.69)\end{array}$ \\
\hline ForProfit & $\begin{array}{l}-1.76 \\
(0.82)\end{array}$ & $\begin{array}{l}-0.62 \\
(0.29)\end{array}$ & $\begin{array}{l}4.91 * * \\
(2.63)\end{array}$ & $\begin{array}{l}1.41 \\
(0.72)\end{array}$ & $\begin{array}{l}3.15^{*} \\
(1.73)\end{array}$ & $\begin{array}{l}1.01 \\
(0.43)\end{array}$ \\
\hline $\mathrm{BA}$ & $\begin{array}{l}-8.00^{*} \\
(1.71)\end{array}$ & $\begin{array}{l}-3.55 \\
(0.67)\end{array}$ & $\begin{array}{l}3.03 \\
(0.73)\end{array}$ & $\begin{array}{l}0.51 \\
(0.19)\end{array}$ & $\begin{array}{l}-5.11 * \\
(1.10)\end{array}$ & $\begin{array}{l}-3.38 \\
(0.58)\end{array}$ \\
\hline MA & $\begin{array}{l}-10.79 \\
(1.44)\end{array}$ & $\begin{array}{l}6.29 * * \\
(1.09)\end{array}$ & $\begin{array}{l}12.25^{*} \\
(1.82)\end{array}$ & $\begin{array}{l}-12.97 * * \\
(2.67)\end{array}$ & $\begin{array}{l}1.15 \\
(0.19)\end{array}$ & $\begin{array}{l}-8.37 \\
(1.17)\end{array}$ \\
\hline PHD & $\begin{array}{l}-26.70 \\
(0.42)\end{array}$ & $\begin{array}{l}7.82 \\
(0.20)\end{array}$ & $\begin{array}{l}30.88 \\
(0.50)\end{array}$ & $\begin{array}{l}-11.55 \\
(0.35)\end{array}$ & $\begin{array}{l}3.47 \\
(0.08)\end{array}$ & $\begin{array}{l}7.34 \\
(0.22)\end{array}$ \\
\hline $\begin{array}{l}<3 \text { Years } \\
\text { Experience }\end{array}$ & $\begin{array}{l}2.66 \\
(0.36)\end{array}$ & $\begin{array}{l}-10.69^{* *} \\
(1.47)\end{array}$ & $\begin{array}{l}9.20^{*} \\
(1.70)\end{array}$ & $\begin{array}{l}8.04 \\
(1.58)\end{array}$ & $\begin{array}{l}11.78^{*} \\
(1.74)\end{array}$ & $\begin{array}{l}-2.07 \\
(0.24)\end{array}$ \\
\hline $\begin{array}{l}\text { 4to6 Years } \\
\text { Experience }\end{array}$ & $\begin{array}{l}-5.02 \\
(0.62)\end{array}$ & $\begin{array}{c}3.55 \\
(0.45)\end{array}$ & $\begin{array}{l}9.10^{*} \\
(1.74)\end{array}$ & $\begin{array}{l}8.23 \\
(1.22)\end{array}$ & $\begin{array}{l}3.45 \\
(0.45)\end{array}$ & $\begin{array}{l}13.24 \\
(1.43)\end{array}$ \\
\hline $\begin{array}{l}>10 \text { Years } \\
\text { Experience }\end{array}$ & $\begin{array}{c}2.13 \\
(0.27)\end{array}$ & $\begin{array}{l}-14.30^{* *} \\
(1.97)\end{array}$ & $\begin{array}{l}6.03 \\
(1.09)\end{array}$ & $\begin{array}{l}10.62^{*} \\
(1.69)\end{array}$ & $\begin{array}{l}8.07 \\
(1.15)\end{array}$ & $\begin{array}{l}-3.28 \\
(0.38)\end{array}$ \\
\hline R-squared & 0.42 & 0.53 & 0.42 & 0.53 & 0.42 & 0.50 \\
\hline Obs & 236 & 223 & 236 & 223 & 236 & 223 \\
\hline
\end{tabular}

Notes. t-statistics are in parentheses and the asterisks indicate significance as follows: $* * *=1 \%, * *=5 \%, *=10 \%$. 


\section{APPENDIX}

Table A.5 Estimated Determinants of Student Achievement, 2002-03, 2003-04

Dependent Variable: Average Test Score on AIMS Exam

\begin{tabular}{|c|c|c|c|c|c|c|}
\hline $5^{\text {th }}$ Grade & \begin{tabular}{|l} 
Meet \\
2002-03
\end{tabular} & $\begin{array}{l}\text { Meet } \\
\text { 2003-04 }\end{array}$ & $\begin{array}{l}\text { Exceed } \\
2002-03\end{array}$ & $\begin{array}{l}\text { Exceed } \\
\text { 2003-04 }\end{array}$ & $\begin{array}{l}\text { Meet + Exceed } \\
2002-03\end{array}$ & $\begin{array}{l}\text { Meet + Exceed } \\
\text { 2003-04 }\end{array}$ \\
\hline Intercept & $\begin{array}{l}25.92^{*} \\
(1.86)\end{array}$ & $\begin{array}{l}14.28 \\
(1.20)\end{array}$ & $\begin{array}{l}20.88 \\
(1.56)\end{array}$ & $\begin{array}{l}12.83^{*} \\
(1.88)\end{array}$ & $\begin{array}{l}64.25^{* * *} \\
(4.28)\end{array}$ & $\begin{array}{l}38.65^{* * *} \\
(3.37)\end{array}$ \\
\hline $\begin{array}{l}\text { Score } \\
\text { (Previous } \\
\text { year) }\end{array}$ & $\begin{array}{l}0.80^{* * * *} \\
(17.72)\end{array}$ & $\begin{array}{l}0.78^{* * *} \\
(17.22)\end{array}$ & $\begin{array}{l}0.61^{* * *} \\
(9.15)\end{array}$ & $\begin{array}{l}0.73 * * * \\
(12.20)\end{array}$ & $\begin{array}{l}0.43^{* * * *} \\
(8.10)\end{array}$ & $\begin{array}{l}0.58^{* * * *} \\
(10.76)\end{array}$ \\
\hline $\begin{array}{l}\text { Percent } \\
\text { Minority }\end{array}$ & $\begin{array}{l}6.51^{* *} \\
(2.18)\end{array}$ & $\begin{array}{l}-5.12 \\
(1.38)\end{array}$ & $\begin{array}{l}-3.83 \\
(1.45)\end{array}$ & $\begin{array}{l}-6.99 * * \\
(3.39)\end{array}$ & $\begin{array}{l}-23.00^{* * *} \\
(5.26)\end{array}$ & $\begin{array}{l}-19.40^{* * *} \\
(4.62)\end{array}$ \\
\hline Income & $\begin{array}{l}-0.24 \\
(0.95)\end{array}$ & $\begin{array}{l}0.02 \\
(0.87)\end{array}$ & $\begin{array}{l}-0.21 \\
(0.85)\end{array}$ & $\begin{array}{l}-0.01 \\
(0.63)\end{array}$ & $\begin{array}{l}-0.17 \\
(0.57)\end{array}$ & $\begin{array}{c}0.03 \\
(1.23)\end{array}$ \\
\hline ForProfit & $\begin{array}{l}6.15^{* *} \\
(2.60)\end{array}$ & $\begin{array}{l}-3.75 \\
(1.62)\end{array}$ & $\begin{array}{l}1.82 \\
(0.77)\end{array}$ & $\begin{array}{l}-0.88 \\
(0.59)\end{array}$ & $\begin{array}{l}5.53^{* *} \\
(2.13)\end{array}$ & $\begin{array}{l}-3.10 \\
(1.37)\end{array}$ \\
\hline $\mathrm{BA}$ & $\begin{array}{l}1.65 \\
(0.33)\end{array}$ & $\begin{array}{l}-2.72 \\
(0.53)\end{array}$ & $\begin{array}{l}2.84 \\
(0.65)\end{array}$ & $\begin{array}{l}-1.01 \\
(0.33)\end{array}$ & $\begin{array}{l}1.25 \\
(0.21)\end{array}$ & $\begin{array}{l}-4.68 \\
(0.83)\end{array}$ \\
\hline MA & $\begin{array}{l}-4.78 \\
(0.61)\end{array}$ & $\begin{array}{l}1.05 \\
(0.15)\end{array}$ & $\begin{array}{l}-4.66 \\
(0.64)\end{array}$ & $\begin{array}{l}-3.65 \\
(0.99)\end{array}$ & $\begin{array}{l}-12.88 \\
(1.41)\end{array}$ & $\begin{array}{l}-0.64 \\
(0.09)\end{array}$ \\
\hline PHD & $\begin{array}{l}-46.59 \\
(0.97)\end{array}$ & $\begin{array}{l}40.87 \\
(0.92)\end{array}$ & $\begin{array}{l}16.25 \\
(0.33)\end{array}$ & $\begin{array}{l}31.94 \\
(0.99)\end{array}$ & $\begin{array}{l}-45.88 \\
(0.98)\end{array}$ & $\begin{array}{l}75.41 \\
(1.49)\end{array}$ \\
\hline $\begin{array}{l}<3 \text { Years } \\
\text { Experience }\end{array}$ & $\begin{array}{l}-10.49 \\
(0.96)\end{array}$ & $\begin{array}{l}-5.63 \\
(0.64)\end{array}$ & $\begin{array}{l}-13.48 \\
(1.25)\end{array}$ & $\begin{array}{l}-10.43^{* *} \\
(1.96)\end{array}$ & $\begin{array}{l}-28.78 \\
(2.53)\end{array}$ & $\begin{array}{l}-18.57^{* *} \\
(2.51)\end{array}$ \\
\hline $\begin{array}{l}\text { 4to6 Years } \\
\text { Experience }\end{array}$ & $\begin{array}{l}-14.85 \\
(1.14)\end{array}$ & $\begin{array}{l}-7.13 \\
(0.81)\end{array}$ & $\begin{array}{l}-11.67 \\
(0.97)\end{array}$ & $\begin{array}{l}-7.20 \\
(1.38)\end{array}$ & $\begin{array}{l}-16.43 \\
(1.24)\end{array}$ & $\begin{array}{l}-14.30^{*} \\
(1.92)\end{array}$ \\
\hline $\begin{array}{l}>10 \text { Years } \\
\text { Experience }\end{array}$ & \begin{tabular}{|l|}
-9.74 \\
$(0.72)$
\end{tabular} & $\begin{array}{l}-11.18 \\
(1.14)\end{array}$ & $\begin{array}{l}13.30 \\
(1.00)\end{array}$ & $\begin{array}{l}-1.20 \\
(0.18)\end{array}$ & $\begin{array}{l}-23.01 * * \\
(1.73)\end{array}$ & $\begin{array}{l}-9.70^{* *} \\
(1.12)\end{array}$ \\
\hline R-squared & 0.62 & 0.61 & 0.45 & 0.68 & 0.57 & 0.64 \\
\hline Observations & 217 & 215 & 217 & 215 & 220 & 215 \\
\hline
\end{tabular}

Notes. t-statistics are in parentheses and the asterisks indicate significance as follows: $* * *=1 \%, * *=5 \%, *=10 \%$. 


\section{APPENDIX \\ Table A.6 Variable Definitions and Data Sources}

\begin{tabular}{|c|c|c|}
\hline Variable & Definition & Source \\
\hline $\begin{array}{l}\text { Score } \\
\text { (Previous year) }\end{array}$ & $\begin{array}{l}\text { average test score for each charter school from the Arizona's } \\
\text { Instrument to Measure Standards and Stanford } 9 \text { exams }\end{array}$ & $\mathrm{A}$ \\
\hline $\begin{array}{l}\text { Percent } \\
\text { Minority }\end{array}$ & percent of minority students in each charter school & A \\
\hline Income & per capita income by county & $\mathrm{B}$ \\
\hline ForProfit & legal entity of each charter school & A \\
\hline BA & $\begin{array}{l}\text { percent of teachers in each charter school with a bachelor's } \\
\text { degree }\end{array}$ & A \\
\hline MA & $\begin{array}{l}\text { percent of teachers in each charter school with a master's } \\
\text { degree }\end{array}$ & A \\
\hline PHD & $\begin{array}{l}\text { percent of teachers in each charter school with a doctoral } \\
\text { degree }\end{array}$ & A \\
\hline $\begin{array}{l}<3 \text { Years } \\
\text { Experience }\end{array}$ & $\begin{array}{l}\text { percent of teachers in each charter school with less than } \\
\text { three years experience }\end{array}$ & A \\
\hline $\begin{array}{l}\text { 4to6 Years } \\
\text { Experience }\end{array}$ & $\begin{array}{l}\text { percent of teachers in each charter school with four to six } \\
\text { years of experience }\end{array}$ & A \\
\hline $\begin{array}{l}>10 \text { Years } \\
\text { Experience }\end{array}$ & $\begin{array}{l}\text { percent of teachers in each charter school greater than ten } \\
\text { years of experience }\end{array}$ & A \\
\hline
\end{tabular}

Sources

A: Arizona Department of Education, Directory of Arizona Charter Schools, School Report Cards, AIMS results and Stanford 9 results, 2000-03.

B: Bureau of Economic Analysis: Regional Economic Accounts, Custom Table Creator, http://www.bea.doc.gov/bea/regional/reis/, 2000-2002. 


\section{APPENDIX}

Table A.7 Cleveland Municipal and Comparable School Characteristics

\begin{tabular}{|c|c|c|c|c|c|c|c|c|c|c|}
\hline District & County & $\begin{array}{c}\text { Average } \\
\text { Daily } \\
\text { Membership } \\
\text { (ADM) }\end{array}$ & $\begin{array}{c}\text { Poverty } \\
\text { as of } \\
\text { ADM }\end{array}$ & $\begin{array}{c}\% \text { of Population } \\
\text { Administrative } \\
\text { or Professional } \\
\text { Occupations }\end{array}$ & $\begin{array}{c}\text { Median } \\
\text { Income }\end{array}$ & $\begin{array}{c}\text { Population } \\
\text { with } \\
\text { College } \\
\text { Degree or } \\
\text { More }\end{array}$ & $\begin{array}{c}\text { Agricultural } \\
\text { Property }\end{array}$ & $\begin{array}{c}\text { Nopulation } \\
\text { Residential } \\
\text { \& Non- } \\
\text { Density } \\
\text { Agricultural } \\
\text { Per Pupil }\end{array}$ & $\begin{array}{c}\text { \% } \\
\text { Minority } \\
\text { Students }\end{array}$ \\
\hline Cleveland City & Cuyahoga & 76,104 & 60.3 & 22.3 & 21,711 & 15.6 & 0.0 & $6,103.0$ & 44,576 & 81.4 \\
\hline Toledo City & Lucas & 39,066 & 47.9 & 25.1 & 25,316 & 22.8 & 0.2 & $3,574.0$ & 30,695 & 56.0 \\
\hline Dayton City & Montgomery & 23,594 & 51.4 & 25.4 & 23,217 & 20.6 & 0.1 & $3,857.0$ & 41,962 & 73.1 \\
\hline Akron City & Summit & 31,468 & 46.1 & 25.0 & 24,284 & 21.4 & 0.0 & $3,993.0$ & 35,111 & 52.5 \\
\hline Cincinnati City & Hamilton & 44,131 & 40.6 & 36.0 & 25,605 & 32.4 & 0.0 & $4,323.0$ & 72,170 & 74.6 \\
\hline Columbus City & Franklin & 65,222 & 37.4 & 31.6 & 25,701 & 29.6 & 0.2 & $4,029.0$ & 73,851 & 65.8 \\
\hline Canton City & Stark & 11,995 & 39.3 & 19.8 & 21,671 & 14.0 & 0.0 & $4,343.0$ & 34,371 & 44.3 \\
\hline
\end{tabular}

Source: Ohio Department of Education. 


\section{APPENDIX \\ Table A.8 Lakewood City and Comparable School Characteristics}

\begin{tabular}{|c|c|c|c|c|c|c|c|c|c|c|}
\hline District & County & $\begin{array}{c}\text { Average } \\
\text { Daily } \\
\text { Membership } \\
\text { (ADM) }\end{array}$ & $\begin{array}{c}\text { Poverty } \\
\text { as \% of } \\
\text { ADM }\end{array}$ & $\begin{array}{l}\% \text { of Population } \\
\text { Administrative } \\
\text { or Professional } \\
\text { Occupations }\end{array}$ & $\begin{array}{l}\text { Median } \\
\text { Income }\end{array}$ & \begin{tabular}{|c}
$\%$ of \\
Population \\
with \\
College \\
Degree or \\
More \\
\end{tabular} & $\begin{array}{c}\% \\
\text { Agricultural } \\
\text { Property }\end{array}$ & $\begin{array}{c}\text { Population } \\
\text { Density }\end{array}$ & $\begin{array}{c}\text { Non- } \\
\text { Residential } \\
\text { \& Non- } \\
\text { Agricultural } \\
\text { Per Pupil }\end{array}$ & $\begin{array}{c}\% \\
\text { Minority } \\
\text { Students }\end{array}$ \\
\hline Barberton City & Summit & 4,348 & 29.1 & 19.8 & 24,687 & 14.6 & 0.1 & $4,265.0$ & 35,343 & 15.3 \\
\hline Cleveland Hts-Univ Hts City & Cuyahoga & 7,116 & 29.6 & 53.9 & 35,424 & 56.9 & 0.0 & $6,300.0$ & 31,061 & 80.0 \\
\hline Cuyahoga Falls City & Summit & 5,258 & 11.6 & 34.6 & 31,034 & 31.6 & 0.0 & $4,400.0$ & 40,452 & 3.4 \\
\hline Elyria City & Lorain & 8,279 & 26.0 & 23.9 & 27,045 & 20.6 & 0.4 & $2,178.0$ & 51,535 & 30.5 \\
\hline Euclid City & Cuyahoga & 6,324 & 29.6 & 30.6 & 28,193 & 25.3 & 0.0 & $4,932.0$ & 49,622 & 68.2 \\
\hline Garfield Heights City & Cuyahoga & 3,854 & 21.5 & 24.7 & 28,810 & 17.9 & 0.0 & $3,832.0$ & 34,138 & 24.5 \\
\hline Hamilton City & Butler & 9,483 & 33.3 & 22.3 & 26,316 & 16.2 & 0.4 & $3,806.0$ & 31,423 & 17.1 \\
\hline Kettering City & Montgomery & 7,590 & 4.2 & 39.2 & 32,249 & 38.8 & 0.0 & $2,660.0$ & 72,756 & 5.7 \\
\hline Lakewood City & Cuyahoga & 6,640 & 24.0 & 41.0 & 30,946 & 41.4 & 0.0 & $10,511.0$ & 28,401 & 11.3 \\
\hline Middletown City & Butler & 7,641 & 29.0 & 23.9 & 27,068 & 18.1 & 0.3 & $2,023.0$ & 69,039 & 22.6 \\
\hline Newark City & Licking & 6,957 & 31.1 & 24.0 & 25,188 & 20.8 & 0.6 & $1,767.0$ & 34,797 & 8.0 \\
\hline North Olmsted City & Cuyahoga & 4,536 & 11.8 & 37.6 & 34,162 & 34.0 & 0.0 & $2,939.0$ & 62,064 & 4.8 \\
\hline Parma City & Cuyahoga & 13,540 & 14.4 & 30.9 & 30,587 & 24.7 & 0.0 & $4,097.0$ & 41,296 & 4.9 \\
\hline South Euclid-Lyndhurst City & Cuyahoga & 4,489 & 10.7 & 42.7 & 35,064 & 43.7 & 0.0 & $4,076.0$ & 42,522 & 41.1 \\
\hline Springfield City & Clark & 9,783 & 41.3 & 24.0 & 23,086 & 17.3 & 0.0 & $3,575.0$ & 25,135 & 32.6 \\
\hline West Carrollton City & Montgomery & 3,919 & 15.1 & 30.8 & 30,102 & 26.6 & 0.1 & $2,994.0$ & 49,301 & 12.5 \\
\hline Fairfield City & Butler & 9,625 & 4.1 & 38.1 & 36,278 & 34.0 & 0.8 & $1,569.0$ & 46,093 & 13.9 \\
\hline Northwest Local & Hamilton & 10,623 & 10.6 & 32.5 & 33,386 & 29.7 & 0.6 & $1,756.0$ & 36,563 & 22.0 \\
\hline Washington Local & Lucas & 6,963 & 19.0 & 23.9 & 29,602 & 22.0 & 0.0 & $2,803.0$ & 73,107 & 14.4 \\
\hline Huber Heights City & Montgomery & 6,914 & 12.6 & 31.5 & 33,752 & 30.1 & 0.8 & $1,796.0$ & 25,441 & 21.0 \\
\hline Plain Local & Stark & 6,155 & 16.0 & 35.1 & 31,302 & 30.2 & 1.0 & $1,710.0$ & 30,875 & 13.2 \\
\hline
\end{tabular}

Source: Ohio Department of Education. 


\section{APPENDIX}

Table A.9 Mentor Exempted Village and Comparable School Characteristics

\begin{tabular}{|c|c|c|c|c|c|c|c|c|c|c|}
\hline District & County & $\begin{array}{l}\text { Average Daily } \\
\text { Membership } \\
\text { (ADM) }\end{array}$ & $\begin{array}{c}\text { Poverty } \\
\text { as \% of } \\
\text { ADM }\end{array}$ & $\begin{array}{c}\% \text { of Population } \\
\text { Administrative or } \\
\text { Professional } \\
\text { Occupations }\end{array}$ & $\begin{array}{l}\text { Median } \\
\text { Income }\end{array}$ & \begin{tabular}{|c|}
$\%$ of \\
Population \\
with College \\
Degree or \\
More \\
\end{tabular} & $\begin{array}{c}\% \\
\text { Agricultural } \\
\text { Property }\end{array}$ & $\begin{array}{c}\text { Population } \\
\text { Density }\end{array}$ & \begin{tabular}{|c|} 
Non- \\
Residential \& \\
Non- \\
Agricultural \\
Per Pupil \\
\end{tabular} & $\begin{array}{c}\% \\
\text { Minority } \\
\text { Students }\end{array}$ \\
\hline Mentor Ex Village & Lake & 9,673 & 5.2 & 35.8 & 34,749 & 33.6 & 0.7 & $1,800.0$ & 60,113 & 2.1 \\
\hline Kettering City & Montgomery & 7,590 & 4.2 & 39.2 & 32,249 & 38.8 & 0.0 & $2,660.0$ & 72,756 & 5.7 \\
\hline West Clermont Local & Clermont & 9,094 & 7.7 & 31.0 & 33,312 & 27.4 & 0.9 & $1,364.0$ & 50,440 & 2.7 \\
\hline Strongsville City & Cuyahoga & 7,284 & 0.6 & 42.2 & 42,554 & 43.6 & 0.1 & $1,758.0$ & 56,640 & 5.2 \\
\hline Cuyahoga Falls City & Summit & 5,258 & 11.6 & 34.6 & 31,034 & 31.6 & 0.0 & $4,400.0$ & 40,452 & 3.4 \\
\hline Willoughby-Eastlake City & Lake & 8,718 & 9.0 & 31.0 & 30,898 & 26.4 & 0.4 & $2,147.0$ & 70,991 & 4.9 \\
\hline North Olmsted City & Cuyahoga & 4,536 & 11.8 & 37.6 & 34,162 & 34.0 & 0.0 & $2,939.0$ & 62,064 & 4.8 \\
\hline Parma City & Cuyahoga & 13,540 & 14.4 & 30.9 & 30,587 & 24.7 & 0.0 & $4,097.0$ & 41,296 & 4.9 \\
\hline Stow-Munroe Falls City & Summit & 6,157 & 3.4 & 42.8 & 36,665 & 42.5 & 0.4 & $1,735.0$ & 38,079 & 3.7 \\
\hline Fairfield City & Butler & 9,625 & 4.1 & 38.1 & 36,278 & 34.0 & 0.8 & $1,569.0$ & 46,093 & 13.9 \\
\hline Milford Ex Village & Clermont & 6,189 & 4.9 & 38.9 & 36,763 & 38.3 & 0.7 & $1,122.0$ & 33,295 & 2.9 \\
\hline North Royalton City & Cuyahoga & 4,501 & 5.4 & 38.7 & 37,467 & 37.9 & 0.1 & $1,235.0$ & 39,433 & 2.4 \\
\hline Jackson Local & Stark & 5,626 & 1.6 & 43.1 & 36,968 & 42.5 & 1.9 & 970.0 & 78,517 & 3.5 \\
\hline Oak Hills Local & Hamilton & 8,070 & 5.4 & 34.6 & 34,545 & 33.0 & 0.1 & $1,535.0$ & 20,239 & 3.1 \\
\hline Brunswick City & Medina & 7,211 & 4.6 & 31.3 & 36,543 & 27.4 & 1.5 & $1,454.0$ & 23,934 & 3.1 \\
\hline Medina City & Medina & 7,298 & 4.9 & 38.4 & 39,617 & 41.3 & 4.0 & 835.0 & 44,131 & 5.5 \\
\hline Sylvania City & Lucas & 7,821 & 6.5 & 45.6 & 39,938 & 49.5 & 0.5 & $1,672.0$ & 39,910 & 6.7 \\
\hline North Canton City & Stark & 4,852 & 1.8 & 45.0 & 35,044 & 42.4 & 0.9 & $1,730.0$ & 33,402 & 3.8 \\
\hline Boardman Local & Mahoning & 4,891 & 11.0 & 34.3 & 29,444 & 30.0 & 0.6 & $1,591.0$ & 74,321 & 9.2 \\
\hline Green Local & Summit & 4,235 & 7.2 & 35.1 & 35,582 & 31.9 & 2.0 & 676.0 & 38,441 & 2.4 \\
\hline Miamisburg City & Montgomery & 5,333 & 12.2 & 34.2 & 34,112 & 31.5 & 1.4 & $1,130.0$ & 81,677 & 8.4 \\
\hline
\end{tabular}

Source: Ohio Department of Education. 


\section{APPENDIX}

Table A.10 Willoughby-Eastlake and Comparable School Characteristics

\begin{tabular}{|c|c|c|c|c|c|c|c|c|c|c|}
\hline District & County & $\begin{array}{c}\text { Average } \\
\text { Daily } \\
\text { Membership } \\
\text { (ADM) }\end{array}$ & $\begin{array}{c}\text { Poverty } \\
\text { as \% of } \\
\text { ADM }\end{array}$ & $\begin{array}{c}\% \text { of Population } \\
\text { Administrative } \\
\text { or Professional } \\
\text { Occupations }\end{array}$ & $\begin{array}{l}\text { Median } \\
\text { Income }\end{array}$ & \begin{tabular}{|c|}
$\%$ of \\
Population \\
with \\
College \\
Degree or \\
More \\
\end{tabular} & $\begin{array}{c}\% \\
\text { Agricultural } \\
\text { Property }\end{array}$ & $\begin{array}{c}\text { Population } \\
\text { Density }\end{array}$ & $\begin{array}{c}\text { Non- } \\
\text { Residential \& } \\
\text { Non- } \\
\text { Agricultural } \\
\text { Per Pupil }\end{array}$ & $\begin{array}{c}\% \\
\text { Minority } \\
\text { Students }\end{array}$ \\
\hline Willoughby-Eastlake City & Lake & 8,718 & 9.0 & 31.0 & 30,898 & 26.4 & 0.4 & $2,147.0$ & 70,991 & 4.9 \\
\hline West Clermont Local & Clermont & 9,094 & 7.7 & 31.0 & 33,312 & 27.4 & 0.9 & $1,364.0$ & 50,440 & 2.7 \\
\hline Boardman Local & Mahoning & 4,891 & 11.0 & 34.3 & 29,444 & 30.0 & 0.6 & $1,591.0$ & 74,321 & 9.2 \\
\hline North Olmsted City & Cuyahoga & 4,536 & 11.8 & 37.6 & 34,162 & 34.0 & 0.0 & $2,939.0$ & 62,064 & 4.8 \\
\hline Findlay City & Hancock & 6,049 & 14.4 & 30.1 & 29,016 & 31.2 & 1.1 & $1,086.0$ & 52,611 & 9.6 \\
\hline Miamisburg City & Montgomery & 5,333 & 12.2 & 34.2 & 34,112 & 31.5 & 1.4 & $1,130.0$ & 81,677 & 8.4 \\
\hline Perry Local & Stark & 4,809 & 10.0 & 26.2 & 30,142 & 19.6 & 1.6 & $1,223.0$ & 46,240 & 6.1 \\
\hline Mentor Ex Village & Lake & 9,673 & 5.2 & 35.8 & 34,749 & 33.6 & 0.7 & $1,800.0$ & 60,113 & 2.1 \\
\hline Washington Local & Lucas & 6,963 & 19.0 & 23.9 & 29,602 & 22.0 & 0.0 & $2,803.0$ & 73,107 & 14.4 \\
\hline Lancaster City & Fairfield & 6,117 & 16.8 & 25.3 & 26,820 & 20.7 & 3.3 & 846.0 & 52,804 & 2.3 \\
\hline Kettering City & Montgomery & 7,590 & 4.2 & 39.2 & 32,249 & 38.8 & 0.0 & $2,660.0$ & 72,756 & 5.7 \\
\hline Troy City & Miami & 4,506 & 14.2 & 33.6 & 30,834 & 27.6 & 2.2 & 736.0 & 62,696 & 10.8 \\
\hline Delaware City & Delaware & 4,449 & 12.9 & 36.9 & 33,837 & 32.4 & 1.4 & 765.0 & 55,478 & 8.5 \\
\hline Berea City & Cuyahoga & 7,544 & 11.7 & 28.2 & 31,311 & 21.3 & 0.0 & 430.0 & 92,166 & 7.4 \\
\hline Austintown Local & Mahoning & 5,138 & 12.8 & 26.4 & 29,375 & 22.5 & 1.0 & $1,502.0$ & 37,051 & 9.9 \\
\hline West Carrollton City & Montgomery & 3,919 & 15.1 & 30.8 & 30,102 & 26.6 & 0.1 & $2,994.0$ & 49,301 & 12.5 \\
\hline Howland Local & Trumbull & 3,309 & 14.3 & 34.4 & 32,227 & 28.0 & 1.4 & $1,373.0$ & 82,619 & 7.4 \\
\hline Oregon City & Lucas & 3,870 & 9.9 & 26.8 & 32,366 & 22.8 & 4.2 & 373.0 & 69,285 & 9.2 \\
\hline Medina City & Medina & 7,298 & 4.9 & 38.4 & 39,617 & 41.3 & 4.0 & 835.0 & 44,131 & 5.5 \\
\hline Fairfield City & Butler & 9,625 & 4.1 & 38.1 & 36,278 & 34.0 & 0.8 & $1,569.0$ & 46,093 & 13.9 \\
\hline Marysville Ex Village & Union & 4,775 & 9.6 & 27.4 & 37,938 & 22.3 & 13.1 & 181.0 & 69,231 & 2.6 \\
\hline
\end{tabular}

Source: Ohio Department of Education. 
APPENDIX

Table A.11 Voucher Estimation Results: School Year 2002-03 and 2003-04

\begin{tabular}{|c|c|c|c|c|c|}
\hline & Citizenship & Mathematics & Reading & Science & Writing \\
\hline \multicolumn{6}{|l|}{ Urban School Districts } \\
\hline $\begin{array}{l}\text { CLEVELAND } 4^{\text {th }} \\
\text { Voucher 2002-03 }\end{array}$ & $\begin{array}{l}11.3628^{* *} \\
(2.03)\end{array}$ & $\begin{array}{l}-0.8471 \\
(0.14)\end{array}$ & $\begin{array}{l}8.0527 \\
(1.37)\end{array}$ & $\begin{array}{l}10.8228^{*} \\
(1.66)\end{array}$ & $\begin{array}{l}8.8687 \\
(1.61)\end{array}$ \\
\hline $\begin{array}{l}\text { CLEVELAND } 4^{\text {th }} \\
\text { Voucher 2003-04 }\end{array}$ & $\begin{array}{l}9.0260 \\
(1.38)\end{array}$ & $\begin{array}{l}13.6833^{*} \\
(1.86)\end{array}$ & $\begin{array}{l}-4.1580 \\
(0.66)\end{array}$ & $\begin{array}{l}13.6326^{*} \\
(1.85)\end{array}$ & $\begin{array}{l}14.3245^{* *} \\
(2.37)\end{array}$ \\
\hline $\begin{array}{l}\text { LAKEWOOD } 4^{\text {th }} \\
\text { Voucher 2002-03 }\end{array}$ & $\begin{array}{l}-0.2022 \\
(0.06)\end{array}$ & $\begin{array}{l}8.1368^{*} \\
(1.91)\end{array}$ & $\begin{array}{l}3.9603 \\
(1.43)\end{array}$ & $\begin{array}{l}0.7161 \\
(0.17)\end{array}$ & $\begin{array}{l}6.6164^{*} \\
(1.77)\end{array}$ \\
\hline $\begin{array}{l}\text { LAKEWOOD } 4^{\text {th }} \\
\text { Voucher 2003-04 }\end{array}$ & $\begin{array}{l}4.3796 \\
(0.88)\end{array}$ & $\begin{array}{l}-3.8048 \\
(0.92)\end{array}$ & $\begin{array}{l}7.3280^{*} \\
(1.93)\end{array}$ & $\begin{array}{l}-2.1199 \\
(0.52)\end{array}$ & $\begin{array}{l}-2.4800 \\
(0.89)\end{array}$ \\
\hline \multicolumn{6}{|l|}{ Rural School Districts } \\
\hline $\begin{array}{l}\text { MENTOR } 4^{\text {th }} \\
\text { Voucher 2002-03 }\end{array}$ & $\begin{array}{l}-0.0481 \\
(0.03)\end{array}$ & $\begin{array}{l}-1.0311 \\
(0.44)\end{array}$ & $\begin{array}{l}0.7441 \\
(0.45)\end{array}$ & $\begin{array}{l}-1.2216 \\
(0.49)\end{array}$ & $\begin{array}{l}-1.7666 \\
(1.38)\end{array}$ \\
\hline $\begin{array}{l}\text { MENTOR } 4^{\text {th }} \\
\text { Voucher 2003-04 }\end{array}$ & $\begin{array}{l}2.4172 \\
(1.22)\end{array}$ & $\begin{array}{l}1.6629 \\
(0.91)\end{array}$ & $\begin{array}{l}1.1635 \\
(0.90)\end{array}$ & $\begin{array}{l}5.0548^{* *} \\
(2.73)\end{array}$ & $\begin{array}{l}0.2997 \\
(0.21)\end{array}$ \\
\hline $\begin{array}{l}\text { WILLOUGHBY-EASTLAKE } \\
4^{\text {th }} \text { Voucher } 2002-03\end{array}$ & $\begin{array}{l}-1.3252 \\
(0.52)\end{array}$ & $\begin{array}{l}1.5782 \\
(0.49)\end{array}$ & $\begin{array}{l}3.8385 \\
(1.56)\end{array}$ & $\begin{array}{l}1.2174 \\
(0.37)\end{array}$ & $\begin{array}{l}-1.9877 \\
(1.04)\end{array}$ \\
\hline $\begin{array}{l}\text { WILLOUGHBY-EASTLAKE } \\
4^{\text {th }} \text { Voucher } 2003-04\end{array}$ & $\begin{array}{l}5.1835^{*} \\
(1.81)\end{array}$ & $\begin{array}{l}2.4937 \\
(0.96)\end{array}$ & $\begin{array}{l}-0.6995 \\
(0.35)\end{array}$ & $\begin{array}{l}6.1016^{* *} \\
(2.08)\end{array}$ & $\begin{array}{l}2.3475 \\
(1.22)\end{array}$ \\
\hline $\begin{array}{l}\text { Pooled Estimation } \\
\text { Results } \\
4^{\text {th }} \text { Voucher } 2002-03\end{array}$ & $\begin{array}{l}3.2339 * * \\
(3.03)\end{array}$ & $\begin{array}{l}4.8560^{* *} \\
(3.61)\end{array}$ & $\begin{array}{l}9.0622 * * * \\
(8.34)\end{array}$ & $\begin{array}{l}4.4946^{* *} \\
(3.23)\end{array}$ & $\begin{array}{l}0.4252 * * \\
(0.43)\end{array}$ \\
\hline $4^{\ln }$ Voucher 2003-04 & $\begin{array}{l}4.7080^{* * *} \\
(4.06)\end{array}$ & $\begin{array}{l}2.6084^{* *} \\
(2.02)\end{array}$ & $\begin{array}{l}0.8756 \\
(0.84)\end{array}$ & $\begin{array}{l}6.3562^{* * *} \\
(4.75)\end{array}$ & $\begin{array}{l}3.2339 * * \\
(3.03)\end{array}$ \\
\hline $\begin{array}{l}\text { Pooled Estimation } \\
\text { Results with Interaction } \\
\text { Term } \\
4^{\text {th }} \text { Voucher } 2002-03\end{array}$ & $\begin{array}{l}6.1740 * * * \\
(3.39)\end{array}$ & $\begin{array}{l}6.9211 * * \\
(3.45)\end{array}$ & $\begin{array}{l}12.8566 * * * \\
(7.35)\end{array}$ & $\begin{array}{l}7.7270 * * * \\
(3.46)\end{array}$ & $\begin{array}{l}5.3958 * * * \\
(3.34)\end{array}$ \\
\hline $4^{\text {th }}$ Voucher $2003-04$ & $\begin{array}{l}0.7565 \\
(0.38)\end{array}$ & $\begin{array}{l}-2.6679 \\
(1.44)\end{array}$ & $\begin{array}{l}-0.4790 \\
(0.28)\end{array}$ & $\begin{array}{l}5.6104 * * \\
(2.37)\end{array}$ & $\begin{array}{l}-1.1582 \\
(0.71)\end{array}$ \\
\hline
\end{tabular}




\section{References}

Anderson, John E., 2003. Public Finance. Houghton Mifflin Company, 15-16, 90-91.

Anselin, Luc, 1988. Spatial Econometrics: Methods and Models. Kluwer Academic Publishers: Dordrecht.

Archer, Glenn L., 1970. “Parochiaid? No!” Educational Leadership, (November 1971), 105-107.

Arizona Department of Education. Directory of Arizona Charter Schools, School Report Cards, and AIMS results. 2000-03. [Online] Available at URL

http://www.ade.state.az.us/, [Accessed 23 October 2004].

Bator, Francis M., 1958. “The Anatomy of Market Failure," Quarterly Journal of Economics 72, 351-379.

Bergstrom, Theodore C., and Robert P. Goodman, 1973. "Private Demand for Public Goods," American Economic Review 63, 280-296.

Betts, Julian R., 1995. "Does School Quality Matter? Evidence from the National Longitudinal Survey of Youth," Review of Economics and Statistics 77(2), 231-250.

Black, Duncan, 1958. The Theory of Committees and Elections. Cambridge University Press, Cambridge.

Borcherding, Thomas E., and Robert T. Deacon, 1972. "The Demand for the Services of Non-Federal Governments," American Economic Review 62, 891-901.

Bowen, H.R., 1943. "The Interpretation of Voting in the Allocation of Economic Resources," Quarterly Journal of Economics 58, 27-48.

Bradford, David, and Wallace Oates, 1971. "Towards a Predictive Theory of Intergovernmental Grants," American Economic Review 61, 440-448.

Bruce, Neil, 2001. Public Finance and the American Economy. Addison-Wesley Longman, 94-95.

Buchanan, James M., 1962. "Politics, Policy, and the Pigouvian Margins," Economica 29, 17-28.

Buchanan, James M. and W. Craig Stubblebine, 1962. "Externality," Economica 9, 371384.

Bulkley, Katrina and Jennifer Fisler, 2002. "An Overview of the Research on Charter Schools," CPRE Web Paper Series WP-01. 
Bureau of Economic Analysis: Regional Economic Accounts, Custom Table Creator, 2000-2002, [Online] Available at URL http://www.bea.doc.gov/bea/regional/reis/, [Accessed 12 November 2004].

Caire, Kaleem, M.S., 2002. "The Truth About Vouchers," Educational Leadership 59(7) $38-43$

Card, David, and Alan B. Krueger, 1996. "School Resources and Student Outcomes: An Overview of the Literature and New Evidence from North and South Carolina," Journal of Economic Perspectives 10(4), 31-41.

Center for Education Reform, The. 2004. Charter Schools state-by-state numbers. Washington, DC: [Online] Available at URL http://edreform.com/index, [Accessed 23 March 2005].

Children's Scholarship Fund, 2001. About CSF: Facts, [Online] Available at URL http://www.scholarshipfund.org/about/facts.asp, [Accessed 3 April 2005].

Chen, Zhiqi, and Edwin G. West, 2000. "Selective Versus Universal Vouchers:

Modeling Median Voter Preferences in Education," American Economic Review 90(5) 1520-1534.

Chubb, John E., and Terry M. Moe, 1990. Politics, Markets, and America's Schools. Washington, DC: The Brookings Institution.

Cliff, A., and J. Ord, 1981. Spatial Processes, Models, and Applications: Pion: London.

Coase, Ronald H., 1960. "The Problem of Social Cost," Journal of Law and Economics $3(1), 1-44$.

Coleman, James S., 1966. Equality of Educational Opportunity, Washington, D.C.: U.S. Government Printing Office.

Cookson, P. W., 1992. "The Ideology of Consumership and the Coming Deregulation of the Public School System," in Peter Cookson, Jr. ed., The Choice Controversy, Newbury Park, California: Corwin Press, Inc., 83-99.

Cullen, Julie Berry, Brian A. Jacob, and Steven Levitt, 2004. "The Effect of School Choice on Student Outcomes: Evidence from Randomized Lotteries." NBER Working Paper No. 10113.

Cullis, John, and Philip Jones, 1998. Public Finance and Public Choice. New York: Oxford University Press, 357-63. 
Data and Program Library Service (DPLS), 2005. [Online] Available at URL http://dpls.dacc.wisc.edu/dpls_mission.html, [Accessed 28 March 2005].

Darling-Hammond, Linda, 2000. "Teacher Quality and Student Achievement: A Review of State Policy Evidence," Education Policy Analysis Archives 8 (1).

Davie, Bruce F., and Bruce F. Duncombe, 1972. Public Finance. Holt, Rinehart and Winston, Inc., 68-70.

Deno, Kevin T., and Stephen L. Mehay, 1987. "Municipal Management Structure and Fiscal Performance: Do City Managers Make a Difference?" Southern Economic Journal 53, 627-642.

Downs, Anthony, 1957. An Economic Theory of Democracy. Harper and Row, New York.

Education Commission of the States. 2005. Vouchers, Tax Credits and Tax Deductions: Laws as of 8/03. Denver, CO. [Online] Available at URL http://www.ecs.org, [Accessed 7 April 2005].

Education Weekly, 2005. Choice, [Online] Available at URL http://www.edweek.org, [Accessed 7 April 2005].

Epple, Dennis, and Richard E. Romano, 1998. "Competition between Public and Private Schools, Vouchers, and Peer-Group Effects," American Economic Review 88(1), 33-62.

Feenberg, D.R., and H.S. Rosen, 1985. "State Personal Income and Sales Taxes: 19771983. NBER Working Paper No. 1631.

Figlio, David N., 1997. "School Choice and Student Performance: Are Private Schools Really Better?" Institute for Research on Poverty, Discussion Paper No. 1141-97.

Fisher, Ronald C., 1996. State and Local Public Finance. Times Mirror Higher Education Group, 49-50, 493-531.

Friedman, Milton, 1962. Capitalism and Freedom. Chicago, University of Chicago Press, 85-107.

Friedman, Milton, 1995. "Public Schools: Make Them Private," Cato Institute Briefing Paper No. 23, (June 23, 1995).

Glaeser, Edward, and Andrei Shleifer, 2001. "Not-for-Profit Entrepreneurs," Journal of Public Economics 81, 99-115.

Glass, Gene V., 2004. The Condition of Choice in Arizona Public Schools: 2004. 
Graham, Grace, 1970. "Can the Public School Survive Another Ten Years?"

Educational Leadership, 800-803.

Greene, Jay P., 2001. "An Evaluation of the Florida A-Plus Accountability and School Choice Program," Manhattan Institute for Policy Research, Center for Civic Innovation, February.

Greene, Jay P. and Marcus A. Winters, 2003. "When Schools Compete: The Effects of Vouchers on Florida Public School Achievement," Education Working Paper 2, [Online] Available at URL http://www.manhattan-institute.org, [Accessed 12 April 2005].

Hanushek Eric A., John F. Kain, Steven G. Rivkin, 2005. "Teachers, Schools, and Academic Achievement," forthcoming, Econometrica.

Hanushek, Eric A., and Steven G. Rivkin, 2003, "Does Public School Competition Affect Teacher Quality?" in Caroline Minter Hoxby ed., The Economics of School Choice, Chicago: University of Chicago Press, 23-47.

Hanushek, Eric, 1996. "Measuring Investment in Education," Journal of Economic Perspectives 10(4), 9-39.

Hanushek, Eric A., 1986. "The Economics of Schooling: Production and Efficiency in Public Schools," Journal of Economic Literature 24, 1141-1177.

Hanushek Eric A., 1971. "Teacher Characteristics and Gains in Student Achievement: Estimation Using Micro Data," American Economic Review 61(2), Papers and Proceedings of the Eighty-Third Annual Meeting of the American Economic Association, 280-288.

Hartocollis, Anemona, 1999. "Private School Choice Plan Draws a Million Aid-Seekers," The New York Times, 21 April 1999, A1, A25.

Henderson, Vernon, Peter Mieszkowski, and Yvon Sauvageau, 1978. "Peer Group Effects and Educational Production Functions," Journal of Public Economics 10, 97-106.

The Heritage Foundation. 2005. Policy Research and Analysis, School Choice, Ohio, [Online] Available at URL http://www.heritage.org/Research/Education/Schools/ohio.cfm, [Accessed 14 April 2005].

Holcombe, Randall G., 1996. Public Finance: Government Revenues and Expenditures in the United States Economy. West Publishing Company, 91-94.

Holcombe, Randall G. and Russell S. Sobel, 1995. "Empirical Evidence on the Publicness of State Legislative Activities," Public Choice 83, 47-58. 
Holcombe, Randall G., 1980. "An Empirical Test of the Median Voter Model," Economic Inquiry 18, 260-274.

Holmes, George M., Jeff DeSimone, and Nicholas G. Rupp, 2003. "Does School Choice Increase School Quality?” NBER Working Paper No. 9683.

Howell, William and Paul Peterson, 2002. The Education Gap. Washington, DC, Brookings Press.

Hoxby, Caroline M. and John Rockoff, 2004. "The Impact of Charter Schools on Student Achievement," HIER Working Paper.

Hoxby, Caroline M., 2004. “A Straightforward Comparison of Charter Schools and Regular Public Schools in the United States," Harvard University and NBER.

Hoxby, Caroline M., 2003. "School Choice and School Productivity (Or, Could School Choice be a Rising Tide that Lifts All Boats,)" in C. Hoxby, ed., The Economics of School Choice. The University of Chicago Press, 287-341.

Hoxby, Caroline M., 2000. "Would School Choice Change the Teaching Profession," NBER Working Paper No. 7866.

Hoxby, Caroline M., 2000. "Does Competition Among Public Schools Benefit Students and Taxpayers?" American Economic Review 90(5), 1209-1238.

Hoxby, Caroline M., 1999. "The Effects of School Choice on Curriculum and Atmosphere," in Susan Mayer and Paul Peterson, eds. Earning and Learning: How Schools Matter. Washington, D.C.: Brookings Institution Press.

Hoxby, Caroline M., 1994. "Do Private Schools Provide Competition for Public Schools?" NBER Working Paper No. 4978.

Husted, Thomas A., and Lawrence W. Kenny, 2000. "Evidence on the Impact of State Government on Primary and Secondary Education and the Equity-Efficiency Trade-Off," Journal of Law and Economics 43(1), 284-308.

Hyman, David N., 2002. Public Finance: A Contemporary Application of Theory to Policy. Harcourt Publishers, 144-146.

Inman, Robert P., 1987. “Testing Political Economy's 'as if' Proposition: Is the Median Income Voter Really Decisive?’ Public Choice 33, 45-65.

Krueger, Alan B., 1999. "Experimental Estimates of Education Production Functions," Quarterly Journal of Economics 114(2), 497-532. 
Ladd, Helen F., and Randall P. Walsh, 2002. "Implementing Value-Added Measures of School Effectiveness: Getting the Incentives Right," Economics of Education Review 21(2), 1-17.

Ladd, Helen F., 2001. "School-Based Educational Accountability Systems: The Promise and the Pitfalls," National Tax Journal 54(2), 385-400.

Langbein, Laura, 2004. "Public School Music: Notes on the Public Provision of a Quasiprivate Good," Public Choice121, 83-98.

Lyons, Thomas W., 1970. "Parochiaid? Yes!” Educational Leadership, (November 1971), 102-104.

Metcalf, K., 2001. Evaluation of the Cleveland scholarship program, 1998-2000:

Technical report. Bloomington: Indiana Center for Evaluation, Indiana University.

Metcalf, Kim K. 1999. "Evaluation of the Cleveland Scholarship and Tutoring Program, 1996-1999." Unpublished manuscript, Indiana University.

Moore, D.R., and S. Davenport, 1989. School choice: The new improved sorting machine. Madison: National Center of Effective Secondary Schools, University of Wisconsin.

Miller, Kimberly, 2003. Vouchers seem broken as education 'fix'. The Palm Beach Post. [Online] Available at URL http://www.palmbeachpost.com, [Accessed 20 April 2005].

Molnar, Alex, 2001. "School Vouchers: The Law, the Research, and Public Policy Implications," Presented at The Hechinger Institute on Education and the Media, Teachers College, Columbia University, Seminar on Education for Editorial Writers.

Musgrave, Richard A., 1959. The Theory of Public Finance. McGraw-Hill Book Company, Inc., 42-44.

National Commission on Excellence in Education. 1983. A Nation at Risk: The Imperative for Educational Reform. Washington, DC: U.S. Government Printing Office.

National Education Association, 8 July 1998. "For-Profit Management of Public Schools," [Online] Available at URL http://www.corpwatch.org/article, [Accessed 20 April 2005].

Nunez, D. R., 2001. “Counting Students in Arizona Charter Schools,” Dissertation, Arizona State University.

Ohio Department of Education, Community Schools Rating Data, 2003-2004. [Online] Available at URL http://www.ode.edu, [Accessed 20 October 2004]. 
People for the American Way Foundation, Existing Voucher and Tuition Tax Credit Programs- At A Glance, [Online] Available at URL http://www.pfaw.org, [Accessed 20 March 2004].

Peterson, Paul E., William G. Howell, and Jay P. Greene, 1998. "An Evaluation of the Cleveland Voucher Program After Two Years," Harvard Program on Education Policy and Governance Working Paper.

Pigou, A. C., 1920. The Economics of Welfare. London: McMillan and Company.

Pogue, Thomas F., James Maxey, and Chia-Hsing Lu, 1999. "Outcomes of Public Education: Weighing the Effects of Dollars, Family, Peers, and Community," National Tax Association Proceedings, Washington, DC: National Tax Association, 222-230.

Raywid, M., 1992. "Choice Orientations, Discussions, and Prospects," in Peter Cookson, Jr. ed., The Choice Controversy, Newbury Park, California: Corwin Press, Inc., 3-23.

Rosen, Harvey S., 2002. Public Finance. McGraw-Hill Irwin, 70-76.

Rouse Cecilia, 1998. "Private School Vouchers and Student Achievement: An Evaluation of the Milwaukee Parental Choice Program?" Quarterly Journal of Economics 113(2), 553-602.

School Choice Facts, 2002. [Online] Available at URL http://www.SchoolChoichInfo.org, [Accessed 28 March 2005].

Smith, Adam, 1776. An Inquiry into the Nature and Causes of the Wealth of Nations. Chicago: Encyclopedia Britannica, c1952.

Sobel, Russell S., 2004. "Welfare Economics and Public Finance," Chapter 2 in Handbook of Public Finance, Jurgen G. Backhaus and Richard E. Wagner, eds., Kluwer Academic Publishers, 19-51.

Stiglitz, Joseph E., 2002. Economics of the Public Sector. W.W. Norton \& Company Inc.

Summers, Anita A., and Barbara L. Wolfe, 1977. "Do Schools Make a Difference?" American Economic Review 67(4), 639-652.

Taylor, Corinne, 1999. "Challenges in Linking Student Outcomes and School Expenditures," National Tax Association Proceedings, Washington, DC: National Tax Association, 231-235.

Teske, Paul, Mark Schneider, Jack Buckley, and Sara Clark, 2000. "Does Charter School Competition Improve Traditional Public Schools?" New York: Manhattan Institute For Policy Research. 
Todd, Petra E., and Kenneth I. Wolpin, 2003. "On the Specification and Estimation of the Production Function for Cognitive Achievement," Economic Journal 113, F3-F33.

Toma, Eugenia F., 1996. "Public Funding and Private Schooling Across Countries," Journal of Law and Economics 39(1), 121-148.

Toma, Eugenia F., 2001. "Education: The Path from Centralization to Privatization," Chapter 9 in Federalist Government in Principle and Practice, Donald Racheter and Richard Wagner eds., Kluwer Academic Publishers, 193-210.

Turnbull, Geoffrey K., and Peter M. Mitias, 1995. "Which Median Voter?” Southern Economic Journal 62, 183-191.

Ulbrich, Holley H., 2003. Public Finance: In Theory and in Practice. South-Western, 342-364.

U.S. Department of Commerce, Bureau of the Census. State Government Finances. Washington DC, various years.

U.S. Department of Commerce, Bureau of the Census. 1980, 1990, 2000. Census of Population. Washington DC.

U.S. Department of Commerce, Bureau of the Census. 1984, 1994, 2003. Statistical Abstract of the United States. Washington DC.

U.S. Department of Education. 1990, 2001. Digest of Education Statistics. Washington DC.

U.S. Department of Education. National Center for Education Statistics, Common Core of Data. Washington DC, various years.

U.S. Department of Education. 1993-94. National Center for Education Statistics, Schools and Staffing Survey. Washington DC.

Utah State Office of Education, Utah Charter Schools Legislation and Regulations. [Online] Available at URL http://www.usoe.k12.ut.us/charterschools/, [Accessed 13 October 2004].

Walberg, Herbert J., and Joseph L. Bast, 2003. Education and Capitalism: How Overcoming Our Fear of Markets and Economics Can Improve America's Schools. Hoover Institution Press Publication No. 521.

WestEd 1997. About the Charter School Movement, History, [Online]Available at URL http://www.uscharterschools.org/pub/uscs_docs/o/history.htm, [Accessed 15 April 2005]. 
Wolf, Patrick J., Paul E. Peterson, and Martin R. West 2001. "Results of a School Voucher Experiment: The Case of Washington, D.C. After Two Years," Paper prepared for the Annual Meetings of the American Political Science Association, August 30September 2, 2001, San Francisco, California. 